\title{
Canadian Mining and Mexican Economic Development
}

by

\section{Sean Cornelissen}

A thesis submitted to the Faculty of Graduate and Postdoctoral Affairs in partial fulfillment of the requirements for the degree of

\section{Master of Arts}

in

Political Economy

Carleton University

Ottawa, Ontario

(C) 2016, Sean Cornelissen 


\begin{abstract}
This thesis is concerned with how Canadian outward FDI in Mexico's mining sector affects the country's economic development. The paper will make the argument that Mexico's economic development has not benefited extensively from Canadian investment in the mining industry, especially considering the revenues earned by mining firms. Furthermore, the argument will be made that inadequate state institutions in Mexico, rather than a malicious Canadian presence, is the principal reason for this phenomenon. Utilizing new institutional economic theory, this thesis will draw attention to the roles of formal and informal institutions in Mexico and how they have affected the mining sector's potential to foster economic development. It will be argued that institutions largely independent of Canadian influence have most significantly affected the outcome of Canadian mining FDI in Mexico's economic development.
\end{abstract}




\section{Acknowledgements}

First and foremost I would like to express my gratitude to my supervisor and the [former] Director of the Institute of Political Economy, Dr. Laura Macdonald. Your constant attention to detail and efficiency as a supervisor were stupendous and greatly appreciated. You gave me the time to digest all of my findings, but at the same time pushed me to continue with the project, which is a difficult balancing act to master. Nevertheless, you seemed to do so effortlessly.

It has been an immense privilege to work with my friend, instructor and mentor, Dr. Pablo Heidrich. The time and effort you invested into teaching me about research methods, different ways to view mining and the global economy, as well as your genuine interest in this thesis topic were absolutely fundamental to its development. I genuinely value the relationship we have built.

I am obliged to my co-supervisor and second reader, Dr. Alex Mallett, for her encouragement, thoughts and very insightful feedback. Your experience and thoroughness added a great deal to the revision of every chapter of my thesis, which I am sincerely thankful for.

I also want to offer my thanks to Dr. Alicia Puyana of FLACSO México. You are an extremely talented researcher and a terrific mentor, thank you for all of your suggestions and for making me feel welcome in such a colossal city.

Without the generosity and openness of each one of my interview subjects in Mexico, the findings and analysis of this thesis would not have been possible. The willingness of each of you to participate in this research project is greatly appreciated. I hope that the experience has been positive and you will consider continuing to participate in academic research, because your opinions are invaluable.

The financial support of MITACS Globalink scholarship and the Institute of Political Economy made my fieldwork possible. It also allowed me to attend various conferences and make connections with industry and academic experts which were useful not only for this project, but will surely continue to be in my future years as a working professional. I would also like to thank the SSHRC for their provision of a grant awarded to Dr. Laura Macdonald entitled, "From Minor Player to Major Actor: Canada's Role in Latin America". This grant allowed me to access the info mine database which was absolutely crucial to my quantitative research findings, and ultimately, my conclusions and analysis.

Various colleagues stand out as being particularly influential to my learning journey while at the Institute of Political Economy, but I would like to thank all of you for your kindness and support. In particular I extend my thanks to Donna Coghill, the Institute of Political Economy administrator, who helped make my time at PECO as smooth and enjoyable as possible. 


\section{Table of Contents}

Abstract..........................................................................................ii

Acknowledgements........................................................................iii

Table of Contents...................................................................iv

Abbreviations............................................................................vi

List of Figures and Appendices..................................................vii

Chapter One - Introduction: Mexican Mining and the Canadian Entrance..................1

Mining for Centuries: A Brief History of Colonial and Post-Colonial Mining in Mexico................................................................

A New Millennium: The Commodity Boom and Mexican Mining in the Current

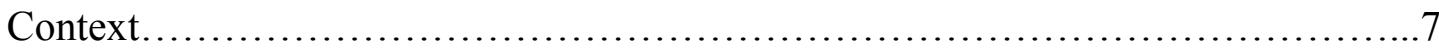

A General Consensus on Canadian Mining in Mexico: Literature Review...........10

Methodology.......................................................... 17

Quantitative Analysis: Production Data Collection and Analysis..........18

Qualitative Analysis: Interviews................................25

Chapter 2 - Theory and Canadian Mining: High Time for a New Approach..............31

Canadian Mining: The Prevailing Theories................................... 32

Giving Agency to Mexican Institutions: A New Theoretical Approach.............42

Chapter 3 - Canadian Mining Firms - Important yet Minority Producers: Empirical

Data Findings....................................................................51

Canadian Entrance to the Market: Gold and Silver Prices.........................57

The Real Economic Significance of Canadian Mining FDI.....................60

Geographical Implications of Canadian Mining................................64

Chapter 4 - Analysis: The Marginal Effect of Canadian Mining Firm's on Mexico's

Economic Development........................................................65

Employment.............................................................. 68

Value Added Products...................................................... 76

Public Revenue........................................................ 87

Introduction of the 2014 Mining Royalty: The Likely Impacts of Canadian Contributions ....................................................... 95

Chapter 5 - Conclusion: Looking Towards the Future................................107 
Appendices...................................................................................117

References.............................................................................127 


\begin{abstract}
Abbreviations
ASF: Auditoria Superior de la Federación (Auditor General's Office of Mexico)

CANMEX: Canada-Mexico Chamber of Commerce

CAMIMEX: Cámara Minera de México (Mexican Chamber of Mining)

CMTF: Canadian Mining Task Force, mining branch of CANMEX

CRD: Committees on Regional Development for Mining Zones

CSR: Corporate Social Responsibility

DGDM: Dirección General para el Desarrollo Minero (Government office for Mining Development within the Secretary of the Economy)

EPN: Enrique Peña Nieto (President of Mexico 2012-present)

FDM: Fondo para el Desarrollo Regional Sustentable de Estados y Municipios Mineros (Regional Sustainable Development Fund for Mining States and Municipalities)

INEGI: Instituto Nacional de Estadísticas y Geología (Mexico's Federal Government Statistics Institute)

ITAM: Instituto Tecnológico Autónoma de México

NIE: New Institutional Economics

M\&A Reports: Merger and Acquisition Reports

PAN: Partido Acción Nacional (National Action Party, Mexico's main Right-Wing political party)

PRI: Partido Revolucionario Institucional (Institutionalized Revolutionary Party, Mexico's main Centre-Left political party)

SHCP: Secretaría de la Hacienda y Cuentas Públicas (Secretary of Public Revenue)

SEDATU: Secretaría de Desarrollo Agrario, Territorial y Urbano (Secretary of Agricultural, Territorial and Urban Development)

TNC: Transnational Corporation

TSX: Toronto Stock Exchange

TSXV: Toronto Stock Exchange Venture

USGS: United States Geological Survey
\end{abstract}




\section{List of Figures and Appendices}

1. Figure 1: Canadian Mines in Mexico vs. Gold and Silver Prices (Pg. 58)

2. Figure 2: Canadian Metal Mining Production in Mexico by Company (Pg. 59)

3. Figure 3: Production Value of Canadian Companies: Displayed as a \% of the Total Mexican Metal Market (Pg. 63)

4. Appendix 1: Mining Production in Mexico (1996-2014) (see Excel document) ${ }^{1}$

5. Appendix 2: Análisis de Canadá dentro del Sector Minero en México - Cornelissen (Pg. 122)

6. Appendix 3: Common Questions Used in Interviews (Pg. 130)

\footnotetext{
${ }^{1}$ This data was collected in part during a Research Assistant position with Pablo Heidrich. The information is only available electronically as the spreadsheets are large and would take up more than 75 pages. Contact the author, Sean Cornelissen, at cornelissensean@gmail.com for more information.
} 


\section{Chapter 1}

\section{Introduction:}

\section{Mexican Mining and the Canadian Entrance}

Throughout the past twenty years Canadian mining ${ }^{2}$ activities in Mexico have largely been viewed in a negative light by scholars, non-profit organizations and social justice advocates. These activists contend that Canadian mining firms have been abusive guests in Mexico, and have left a path of environmental degradation, social upheaval and violence in their wake. More radical writers have made claims regarding the presence of a Canadian mining imperialism in Latin America, citing Mexico as one of the victims of Canadian political and economic authority. It has been made clear that the mining industry has serious consequences that are difficult to measure in dollar terms. However, a thorough understanding of how Canadian mining investment affects Mexico's economic development ${ }^{3}$ has yet to be pursued. Rather than re-examining contemporary debates regarding the social and environmental consequences of mining, I will attempt to uncover the value of Canadian mining to the Mexican economy.

Understanding the economic utility of Canadian mining investments in Mexico raises a number of questions. For example, what are the ways in which Mexico's mining industry most

\footnotetext{
2 Garrod and Macdonald make an important distinction between 'Canadian-based' mining capital and 'Canadian' mining capital, pointing out that many Canadian-based firms are only Canadian in name, and often originate from other countries. However, for the purpose of this paper, Canadian companies are defined as companies which are listed on the TSX, TSXV, and/or have their head office in Canada, regardless of the composition of the board of governors or the company's country of origin. This definition is certain not to understate the relevance of Canadian capital, which is important because the majority of the literature surrounding Canadian mining claims that it is powerful. J.Z. Garrod and Laura Macdonald, "Rethinking 'Canadian Mining Imperialism' in Latin America", chapter in Mining in Latin America: Critical Approaches to the New Extraction Ed. Deonandan, Kalowatie and Dougherty, Michael L. (London: Routledge, 2016).

${ }^{3}$ For the purpose of this paper, economic development is defined as an effort to improve economic well-being and quality of life by creating and/or retaining jobs, increasing incomes and augmenting the tax base.
} 
directly affects the country's economic development? Is the nature and impact of Canadian mining different from that of Mexican mining, and if so, how does this distinction affect that way in which Canadian firms impact Mexico's economic development? What steps have been taken by the Mexican government to ensure that Canadian mining investments positively impact regional and national economies? Following from this, how can a focus on formal and informal institutions ${ }^{4}$ in Mexico help us understand why Canadian mining firms have contributed relatively little to the Mexican economy? I raise these questions in an attempt to inspire a new conversation by re-examining Canadian mining activities in Mexico with a focus on the power held by Mexican authorities to negotiate their own future. In doing so, it is hoped that future research regarding Canadian mining in Latin America will avoid an exclusive focus on the power held by Canadian actors, and will instead consider the agency of host country governments.

I attempt to answer the above questions by focusing on how Canadian mining performs regarding three different economic development indicators: employment, creation of value added products and services, and generation of public revenue. My argument throughout the paper is that Canadian mining contributes very little to the economic development of Mexico's national economy, and less than it should to regional economies, considering the large revenues of mining firms. I take the position that while Canadian firms should be held responsible for illegal and malicious acts, Mexican government authorities are ultimately responsible for ensuring that Canadian investment benefits the Mexican economy. Using new institutional economics (NIE) theory, I outline why Mexican authorities and society have been unsuccessful in taking

\footnotetext{
${ }^{4}$ For the purpose of this paper, I will use Douglass North's definition of institutions. For North, institutions are "humanly devised constraints that structure human interaction" which include: laws, regulations, conventions, norms of behaviour, and the enforcement of these entities.

Source: Douglass North, "New Institutional Economics and Third World Development", chapter in The New Institutional Economics and Third World Development (London: Routledge, 1995): 23.
} 
advantage of the revenues earned by Canadian firms throughout the commodity boom. My argument aims to demonstrate how an exclusive focus on the perceived power of Canadian mining interests is damaging to research projects that attempt to understand how foreign direct investment (FDI) in mining affects development.

The thesis begins by providing a brief historical and literature review regarding Mexican mining leading up to the commodity boom. Next, the methodological design of this research project is laid out. Following this, an understanding of contemporary theoretical approaches to the mining industry in Latin America is provided, and accompanied by an explanation of the theoretical approach used for this paper's analysis - new institutional economics (NIE). The next section outlines the major quantitative empirical findings of the research project. The subsequent section provides an analysis of the empirical findings in the context of NIE, and also includes the project's qualitative findings, which were discovered while doing research in Mexico. The concluding section summarizes the analytical findings of the research project, provides some basic policy suggestions, and indicates a suggested trajectory for future research projects focused on a similar topic.

\section{Mining for Centuries: A Brief History of Colonial and Post-Colonial Mining in Mexico}

Before the arrival of the Spaniards, natives in Mexico had an important cultural appreciation for gold and silver, which were used to craft decorative ornaments. In the precolonial period, gold and silver were normally discovered in the form of powder or nuggets, rather than from mining. ${ }^{5}$ Underground mines were developed by the Spanish starting in 1545 once indigenous hoards were exhausted from plundering. ${ }^{6}$ The gold and silver that was extracted

\footnotetext{
${ }^{5}$ Marvin Bernstein, The Mexican Mining Industry 1890-1950, (State University of New York, New York: 1965): 8.

${ }^{6}$ Ibid.
} 
in Mexico funded the Spanish crown's wars in Europe, as well as further colonization of the Americas. Second only to Bolivia's Potosí mine, Mexico's gold and silver deposits were of great importance to the Spanish new world. In Zacatecas and Guanajuato one can still witness the legacies of gold and silver booms in the exquisite colonial architecture of these mining cities. It is difficult to estimate how much metal was extracted during the colonial period because of falsified and destroyed records, clandestine production, smuggling, and corrupt officials. ${ }^{7}$ Colonial production is thought to have been at its peak in the last decade before Mexican independence (1800-1810) when an estimated 553,800 kilograms of silver and 1,763 kilograms of gold were produced. ${ }^{8}$ Many of the mines were damaged during the War of Independence as they were filled with water, shafts were collapsed and roads were left in disrepair by the retreating Spanish armies. In 1823 the newly born Mexican state invited its first mining investors from England, Germany and the United States (U.S.) to finance mine repairs and recover production. ${ }^{9}$

Foreign investment brought new machinery and new leaching technologies from the English industrial revolution, allowing for the processing of low-grade ores. Towards the end of the $19^{\text {th }}$ century iron one, copper, zinc, coal, cobalt, nickel, and other minerals were discovered which became important inputs for development under the rule of Porfirio Diaz. ${ }^{10}$ From 18761910 Diaz revitalized Mexican mining through foreign investment. As Mexican miners saw foreigners become rich from the extraction of Mexican metals, social unrest became rampant. Unhappy miners became an important part of the momentum built behind the Mexican

\footnotetext{
${ }^{7}$ Ibid: 12 .

${ }^{8}$ Ibid: 12 .

${ }^{9}$ Ibid: 13 .

${ }^{10}$ Ibid: 27
} 
revolution. ${ }^{11}$ After the Mexican Revolution, a new constitution was written in 1917, which states that any type of subsoil material is the property of the Mexican nation. ${ }^{12}$ Nevertheless, foreign capital continued to dominate mining in Mexico until the passing of the 'Mexicanization law' in 1961 which required all mining companies operating in Mexico to be at least 51\% Mexican owned. ${ }^{13}$ Miners formed an important part of the Institutionalized Revolutionary Party's (PRI) corporatist system of governance ${ }^{14}$ during this period and as such were allowed to form unions, and received relatively high salaries. Foreign companies were forced to either sell their properties entirely, or create joint ventures. Within just five years, the largest foreign companies had been transferred in name and title to Mexican owners, effectively creating what are today Mexico's largest three mining companies: Minera Frisco, Industrias Peñoles, and Grupo México. $^{15}$

The massive costs and new technologies that are necessary for mining exploration kept smaller Mexican capitalists from joining the industry, and even dissuaded the established mining companies from exploring new deposits. ${ }^{16}$ The mining law of 1975 institutionalized greater state involvement in the mining industry, which resulted in state purchases of mining properties in

\footnotetext{
${ }^{11}$ Ibid: 280 .

12 Ibid: 287.

${ }^{13}$ Raúl Wise and Rubén Mendoza, "Minería, Estado y Gran Capital en México”, Economía e Sociedad 16 (2001): 109.

${ }^{14}$ Corporatism is defined as the sociopolitical organization of a society based on major interest groups for the purpose of maintaining populist control of key groups in the electorate. The PRI's historical focus on mining as one of its corporatist groups continues to be an important factor as it helps to explain why employment in mining is highly regarded as an important source of jobs by local populations in places where mining has historical ties. Bocking (2013: 333) explains how the Sindicato Nacional de Trabajadores Mineros, Metalúrgicos, Siderúrgicos y Similares de la República Mexicana (SNTMMSSRM) gained official support from PRI President Lazero Cardenas in the 1930s, and by the 1950s it became the union with the most privileged position in relation with the Mexican state. However, in new mining locations that are being developed by many Canadian companies, mining has no historical context and no connection to the benefits associated with corporatism of the 1950s-1990s. This is likely an important reason why new Canadian companies experience more opposition than Mexican companies which largely possess properties that were developed during the days of the PRI's corporatist system of governance.

${ }^{15}$ Wise and Mendoza, "Minería, Estado y Gran Capital en México":, 109-110.

${ }^{16}$ Ibid: 113.
} 
order to exercise national autonomy of natural resources, and maintain employment. The government invested heavily in the purchase and development of mines. In 1983 the Mexican state peaked in its production, extracting about $40 \%$ of the country's metals. ${ }^{17}$

In the early 1980s Mexico experienced a debt crisis, which crippled the country's economy, followed by a boom period in the late 1980s and early 1990s which saw a strong peso, cheap imports, and the appearance of a new middle class in Mexico. ${ }^{18}$ However, Mexico's unstable financial policies eventually resulted in the Mexican peso crisis of 1994 which meant massive devaluations. New loans were acquired from the World Bank (WB) and International Monetary Fund (IMF) with economic restructuring requirements attached. For Mexican mining, this meant the privatization of all state mining reserves and production centres over an eight year period from 1988-1996. ${ }^{19}$ As will be discussed in the literature review, Wise and Mendoza (2001) found that the privatization process was very favourable to the three large Mexican mining companies that were established during the 'Mexicanization' period. The foreign investment law was signed in 1996, giving foreign firms free reign to invest and produce metals in Mexico. The North American Free Trade Agreement (NAFTA), signed in 1994, also gave Canadian and U.S. firms increased access to Mexico's mining sector. Unfortunately for foreign investors, nearly all of the known significant deposits were already owned by large Mexican companies, leaving foreign investors to search for new, generally smaller, deposits. ${ }^{20}$ Throughout $^{2}$ the period of privatization and economic liberalization, mining-specific taxes were not implemented in Mexico nor most other Latin American countries because their focus was on attracting investment during a period of low metal prices in the 1990s. While all other Latin

\footnotetext{
${ }^{17}$ Ibid: 112 .

18 Timothy Kessler, "Political Capital: Mexican Financial Policy under Salinas", World Politics 51.1 (1998): n/a.

${ }^{19}$ Wise and Mendoza, "Minería, Estado y Gran Capital en México": 115.

${ }^{20}$ Wise and Mendoza, "Minería, Estado y Gran Capital en México": 116.
} 
American countries changed their mining tax policies as the commodity boom brought higher metal prices throughout the 2000s, Mexico maintained its taxation rates until 2014.

\section{A New Millennium: The Commodity Boom and Mexican Mining in the Current Context}

Canadian mining in Mexico in the contemporary setting is a fascinating case for a number of reasons. For the majority of the years during the commodity boom (2003-2012) Mexico attracted more foreign mining investment than any other country in Latin America, and was either the fourth or fifth most important FDI destination for mining investment worldwide. ${ }^{21}$ Second, Canadian firms funded by the Toronto Stock Exchange (TSX) and Toronto Stock Exchange Venture (TSXV) are responsible for more mining investment globally than firms from any other country. ${ }^{22}$ In 2013, Canadian firms dominated 73\% of mining investment in Mexico. ${ }^{23}$ Third, Mexico is the world's top producer of silver and is in the top ten producers of more than 15 other metals and minerals such as gold, copper, zinc and iron ore. ${ }^{24}$ The combination of these factors make Mexico's mining industry a particularly interesting case study. Economically speaking, Mexico has been the most important receiver of Canadian FDI since 2003, and it has also been one of the region's most significant producers.

Even though Mexico was considered by industry leaders to be the one of the most important mining countries in the region, the Mexican government viewed the situation in a very distinct manner. In 2010, the year that metal mining was most significant to Mexican exports,

\footnotetext{
${ }^{21}$ Mining Industry in Mexico, Deloitte, May 2012.

${ }^{22}$ It should be mentioned that prior to the influx of Canadian production in Mexico in the late 2000s, the majority of production value in Mexican metal mining was derived from industrial metals extracted by the three large domestic mining companies. Since Canadian production has become a significant force in Mexican mining, gold and silver have been the largest earners of all metals produced in Mexico, followed by copper and iron ore.

23 “Situación de la Minería en México en 2014” Reporte de Situación 2015, CAMIMEX, 15. ${ }^{24} \mathrm{Id}$.
} 
just $2.3 \%$ of the country's exports were derived from this source. ${ }^{25}$ In 2014 , metal mining made up about $1.15 \%$ of Mexico's GDP (with Canadian mining production contributing about $0.45 \%$ of Mexico's total GDP). ${ }^{26}$ From a public revenue point of view, taxes on beer production generated $\$ 11.8$ billion pesos in 2012 , while taxes on mining rights generated only $\$ 2.1$ billion pesos (of which Canadian companies contributed less than $40 \%$ ). ${ }^{27}$ Prior to the mining industry reforms which took effect in January 2014, states and municipalities received no royalties or special income from mining companies operating in their jurisdictions. Top Corporate Income $\operatorname{tax}(\mathrm{TCI})$ in Mexico for mining companies is $30 \%$, the same rate as firms in other industries are obliged to pay. A 7.5\% royalty on metal mining revenues was introduced recently in January 2014, with an additional $0.5 \%$ royalty on gold, silver, and platinum production.

The data presented above illustrate that metal mining in Mexico is very important to Canadian firms that are interested in both investment and production. By extension, this also means that the mining industry in Mexico is likely of great importance to the Canadian government, which seeks to support Canadian mining FDI abroad. ${ }^{28}$ The figures also demonstrate that Canadian mining in Mexico is likely of relatively little importance to the Mexican government because of its small contribution to exports, GDP, and public revenue. The relationship between these two stakeholders is important because it demonstrates that although mining in Mexico is very important to Canadian interests, the Mexican state is not dependent

\footnotetext{
${ }^{25}$ Estadísticas de Exportaciones Mineras, Cuadro 77, 3.2.1, Instituto Nacional de Estadísticas y Geografía (INEGI), 2014.

${ }^{26}$ Canadian mining production figure was extracted from, Appendix 1: Mining Production in Mexico, 1996-2014. The total Mexican GDP (in CDN dollars) was taken from the Global Affairs Canada website, http://international.gc.ca/global-markets-marches-mondiaux/markets-marches/mexico-mexique.aspx?lang=eng, accessed on January 13, 2016.

${ }_{27}$ Análisis de Avance de Informe de Avance de Gestión Financiera, Auditorio General, 2014: 87.

${ }_{28}$ Mexico Country Profile, Canada's Global Market Action Plan, http://international.gc.ca/global-markets-marchesmondiaux/sectors-secteurs/mines.aspx?lang=eng, accessed on September 25, 2015.

The Americas: Canada's Strategy for Engagement in the Americas, Government of Canada document, www.americas.gc.ca, accessed on September 25, 2015.
} 
upon Canadian investment. It demonstrates a trend that is distinct to the assumption of many contemporary activists, who denounce Canadian influence in the mining policies of Latin American countries, including Mexico. The often 'assumed trend' highlights the 'imperialistic' and exploitative nature of the Canada-Latin America relationship. However, the data collected for this research project signifies that a different lens must be adopted in order to understand the Canada-Mexico relationship in regards to mining.

Although Mexico received more foreign investment in mining during the commodity boom than other Latin America countries, that is not to say that other governments in the region did not receive very large investments. In fact, foreign investments in metal mining and other natural resources caused many left-leaning Latin American countries to create new policies which directed public incomes derived from natural resource extraction to social programs. ${ }^{29}$ In some of these countries, the positive economic impact of Canadian mining investment was clearer because one could see the effect of the economic and social development programs which were funded in part by taxes paid by Canadian firms. In Mexico however, the complete absence of a mining specific tax has made it difficult to determine if Canadian mining investments have positively affected the country's economic development. This project aims to clarify how Canadian investment in Mexican mining has affected regional and national economic development in Mexico. Rather than focusing on the role and influence of Canadian actors, it focuses on the institutions present in Mexico that have enabled Canadian firms to contribute less than they should to the country's development process.

\footnotetext{
${ }^{29}$ These policies have become known as 'neo-extractivist', a theory which will be discussed in the Theoretical Approaches section below.
} 
It should be mentioned that much work has been completed highlighting a variety of injustices that have occurred as a result of Canadian mining in Mexico. Five community members opposing the development of three different Canadian mines across Mexico have been killed since 2010, however convictions relating these murders have yet to occur. ${ }^{30}$ As will be discussed in the literature review section to follow, conflicts regarding environmental degradation have also resulted in various forms of protest against other Canadian mining properties. The common denominator in nearly all of these cases is that land claims or fair payment for land was not respected. The protests that result from land claims disputes often end violently for community members, while Canadian firms take a financial hit by a halt in production and falling stock prices. Many NIE scholars claim that contracts surrounding property rights are the most fundamental institution to a country's development. While land rights are not the central focus of this thesis, I argue that a focus on Mexico's institutions will not only help improve how Canadian investment impacts Mexico's economic development, but would also reduce land claims conflicts and therefore reduce violence and other injustices associated with mining.

\section{A General Consensus on Canadian Mining in Mexico: Literature Review}

This section will highlight relevant academic works pertaining to the Mexican mining industry in the twenty-first century. It will attempt to contextualize what has been written about the industry, and how this thesis project fits into the current literature. Literature with a significant theoretical focus is discussed in the 'Dominant Theoretical Approaches' section. I consider that the articles highlighted in this introductory section and the 'Dominant Theoretical

\footnotetext{
${ }^{30}$ Jennifer Moore and Gillian Colgrove, "Corruption, Murder and Canadian Mining in Mexico: The Case of Blackfire Exploration and the Canadian Embassy”, report prepared by Mining Watch Canada (May 2013): 5.
} 
Approaches' section to be an exhaustive list of all the relevant academic work that has been completed on Mexico's mining industry.

The most comprehensive understanding of Mexico's mining history is Minería, Estado y Gran Capital en Mexico by Wise and Mendoza (2001). ${ }^{31}$ The authors accurately describe the stages of nationalization and liberalization in Mexico through an analysis of mining-specific economic policies throughout the twentieth century. The authors found that after the Mexican debt crisis of 1982 the state began to sell nationalized mining properties to Mexican private actors at prices far below their market value throughout the $1980 \mathrm{~s} .{ }^{32}$ Since the foreign investment law was not signed until 1996, the sale of state mining properties was exclusively accessible to Mexican citizens, which created a robust monopoly in the Mexican mining sector. Nearly all of these properties were sold to three very wealthy Mexican citizens ${ }^{33}$ who are currently the three richest men in Mexico. ${ }^{34}$ These individuals are:

1. Alberto Bailleres, owner of Industria Peñoles (currently Mexico's largest mining company) and Mexico's third richest person.

2. Germán Larrea, owner of Grupo México (currently Mexico's second largest mining company) and Mexico's second richest person.

3. Carlos Slim, owner of Minera Frisco (currently Mexico's third largest mining company), and currently the fifth richest person in the world. ${ }^{35}$

\footnotetext{
${ }^{31}$ Wise and Mendoza, "Minería, Estado y Gran Capital en México": 105-127.

${ }^{32}$ Ibid: 115 .

${ }^{33}$ Id: 112.

34 “The World's Billionaires", Forbes website, http://www.forbes.com/billionaires/list/\#country:Mexico, accessed on January 19, 2016.

35 Appendix 1: Mining Production in Mexico, 1996-2014.
} 
The Wise and Mendoza article is very important to this research project as it describes the monopolized setting of the Mexican mining industry at the eve of the commodity boom. I will attempt to build upon Wise and Mendoza's work by examining Mexican mining since the beginning of the $20^{\text {th }}$ century and describing how Canadian firms have impacted Mexico's economic development during this period.

An article by Puyana and Moreno (2016, forthcoming) focuses on the Peña Nieto administration's market reforms in the extractives sectors. ${ }^{36}$ It concentrates on both the mining and petroleum sectors, and points out that Mexico's mining sector is trivial compared to the oil industry. The chapter demonstrates a great understanding of Mexico's importance in the mining sector at a global level, and its insignificance to the Mexican economy and government revenue at a national level. It also concludes that Mexico's new mining taxes came too late, after the commodity boom had already ended. My thesis project will attempt to take these understandings further and ask why the new taxation law came so late, and how comparisons to the oil sector helped to stave off mining taxation throughout the 2000s. My project also agrees with the authors that Mexico's mining sector experienced expansion during the commodity boom, but will seek to explain how Canadian firms dominated that growth, and what Canadian participation means for Mexico's economic development.

Bocking (2013) analysed the formation of unions and labour rights of Mexican miners working for Canadian companies through a case study at La Platosa mine, owned by a Canadian junior company, Excellon Resources. ${ }^{37}$ The author points out that the Mexican Secretary of

\footnotetext{
${ }^{36}$ Alicia Puyana and Juan Carlos Moreno-Brid, "Mexico's New Wave of Market Reforms and its Extractive Industries", chapter in forthcoming book (2016).

${ }^{37}$ Paul Bocking, "Canadian Mining and Labour Struggles in Mexico" Journal of Labour and Society 2013: 331-350.
} 
Labour frequently subverts labour laws and deploys Mexico's armed forces in favour of mining companies, rather than the workers. ${ }^{38}$ He discovered that Excellon Resources did not follow contractual obligations in regards to water salinization and local hiring, and that nearly all Excellon Resource's malicious acts were carried out with the complicity of Mexican government authorities. ${ }^{39}$ The article highlights poor decision-making on the part of the company, but more importantly draws attention to the direct participation and collusion of Mexican authorities in these actions, across all sections of government. While Bocking refrains from accusations against Canadian actors in Mexico, he clearly highlights the malevolent actions of both Excellon Resources and the Mexican government. The article does not address economic development, but it grasps the essential dynamics of Mexico's institutional weaknesses in its relationship with a Canadian mining company. The flaws of some of Mexico's formal institutions highlighted by Bocking are systemic issues that this research project has found to be persistent.

Garibay and Camacho (2009) also wrote a case study based article on the Canadian company Goldcorp's Los Filos mine in the state of Guerrero. ${ }^{40}$ The pair make the argument that the mining giant uses 'negative reciprocity' when dealing with communities near mining projects by making promises with no intention of keeping them, and taking without giving back. The article's focus on the grand divide between how much the mine economically benefits nearby communities, versus how much it benefits Goldcorp is very important. It used extensive participant observation and interviews at Los Filos to explain how little prosperity local economies reap in exchanges with large TNCs.

\footnotetext{
38 Ibid: 332 .

${ }^{39}$ Id: $333,338$.

${ }^{40}$ Claudio Garibay and Alejandra Camacho, "Goldcorp y la Reprocidad Negativa en el Paisaje Minero de Mezcala, Guerrero" UNAM Desacates (2009): 91-110.
} 
There are a number of articles written by Mexican authors on the infamous case of New Gold's Cerro San Pedro mine in San Luis Potosí. ${ }^{41}$ The case drew much media attention because of local opposition to the mine, environmental damage, contamination of water sources, its location in a natural protected area, and irreversible damage to historical buildings. ${ }^{42}$ Protests were held not only in the nearby state capital city, San Luis Potosi, but reached university campuses and politically important parts of Mexico City. The articles highlight how Mexico's Ministry of the Environment ignored independent environmental assessments, the indecisiveness in stopping the mine from operating illegally when its licence was suspended, and that community leaders were arrested and jailed for speaking out. The articles are useful in that they point out institutional problems with Mexico's natural resource governance; but they should not be taken as representative of the entire mining industry.

Tetreault (2014) addresses Mexico’s new Regional Sustainable Development Fund for Mining States and Municipalities (FDM) ${ }^{43}$, which should be a very significant economic development factor for municipal and state governments. ${ }^{44}$ The author employs a critical perspective, focusing on how the reforms failed to increase indigenous autonomy over the ejidos. ${ }^{45}$ Tetreault draws on many effective criticisms of the mining industry throughout the article: precious metals have few industrial applications, the number of murders associated with

\footnotetext{
${ }^{41}$ Pedro Reygadas y Oscar Felipe Reyna Jimenez, "La batalla por San Luis: ¿el agua o el oro? La disputa argumentativa contra la Minera San Xavier” Estudios Demográficos y Urbanos 2.68 (2008): 299-331. Cecilia Costero, "La regionalización de las relaciones inter-nacionales, la inversión canadiense en San Luis Potosí, vista a través de Minera San Xavier”. Revista Mexicana de Estudios Canadienses, 3.4 (2000): 105-117. ${ }^{42}$ Angélica Enciso, "Deja Minera San Xavier un daño irreversible en San Luis Potosí", La Jornada, April 142014 : 33.

${ }^{43}$ In Spanish, Fondo para el Desarrollo Regional Sustentable de Estados y Municipios Mineros (FDM).

${ }^{44}$ Darcy Tetreault, "Megaminería en México: ¿Un Camino hacía el Desarrollo Local and Nacional?” Estudios Críticos del Desarrollo 4.7 (2014): 101-130.

${ }^{45}$ An ejido is a piece of land granted to rural farmers who own the land communally under Mexico's agrarian reform.
} 
mining demonstrations and safety concerns for workers. The article's central argument uses the case study of demonstrations against the creation of a Canadian mine in an indigenous community, Calpulálpam, in the southern state of Oaxaca, to demonstrate mining alternatives. The article describes how by refusing entrance to the mining company, the community was able to develop eco-tourism networks and community forestry industries as alternatives to mining. ${ }^{46}$ The main issue with author's conclusion is that the majority of active and proposed mines in Mexico are in northern states with a desert landscape where both eco-tourism and forestry are not realistic options. Furthermore, the article illustrates the tendency in academia to disregard the need for metals production in modern civilization in order to provide necessary infrastructure such as electricity, water systems, and advanced technology. For example, Maier et al. (2014) explain the relationship between social/environmental well-being and global development needs for metals production. This is an especially important conversation considering the number of people entering the middle class in Asia, growing demands for green electricity and capitalism's constant need of continuous production. ${ }^{47}$ Maier et al. make a call to action for increased interdisciplinary work that acknowledges all of the relevant areas in mining academia: engineering, law, policy making, environmental science, and sociology. ${ }^{48}$

Alternatively, there exist other academic articles which lay out a narrative that Mexican companies have monopolized the mining sector, leaving Canadian companies to pick up the scraps. ${ }^{49}$ This analysis would have been accurate pre-2009, however, a thorough examination of

\footnotetext{
${ }^{46}$ Ibid: 123 .

${ }^{47}$ Maier et al. "Socially Responsible Mining: the Relationship Between Mining and Poverty, Human Health and the Environment", Revision Environ Health 29.2 (2014): 83-89.

${ }^{48}$ Ibid: 87.

49 Tetreault, “Megaminería en México: ¿Un Camino hacía el Desarrollo Local and Nacional?” (2014). María Teresa Gutiérrez Haces, "The Dominance of Mexican Business Groups in the Mining Sector in the Context of the Growing Presence of Canadian Mining Companies”, 2016 forthcoming: 1-22.
} 
production data illustrates that there has been a very significant increase in Canadian-owned production in the last five years. Gutiérrez (2016, forthcoming) acknowledges the new presence of Canadian firms, and highlights how their presence in new territories is creating particularly troubling environmental and social conflicts. ${ }^{50}$ However, the author maintains that Mexican firms continue to "monopolize the mining industry" despite the growing presence of mining FDI. ${ }^{51}$ The production data collection for this research project indicates that mining production in Mexico is currently about $40 \%$ Canadian owned, negating the author's principal supposition. Gutiérrez uses data focused on exploration investments, payments for concession rights and counting companies (regardless of size) in order to arrive at a conclusion of 'Mexican dominance'. The author's attempt to demonstrate that Canadian companies do not dominate Mexico's mining sector is appreciated, considering the overwhelming assumption of the opposite by many other authors. However, contorted data based on pre-production figures allowed the author to incorrectly conclude that there exists a Mexican industrial monopoly in mining. The Dominant Theory section to follow further explores how authors have misused investment and concession-granting data in order to make inappropriate conclusions about Mexico's mining industry.

Case studies have become more common than holistic industrial analysis in Mexican mining literature, as demonstrated by this literature review. These analyses are useful because they provide in-depth detail into the institutional problems that exist in Mexico's mining sector, and therefore provide an understanding of which issues need to be addressed. However, the problem with case study research is that it is often presented as representative of the entire

${ }^{50}$ Gutiérrez Haces, 2016 forthcoming.

${ }^{51}$ Ibid: 3. 
mining industry, or of all Canadian companies, when it is not. The case studies presented here explain how mines affect a few specific communities, but they fail to describe what mining means for employment levels, much-needed diversification of government revenue, or its ability to foment new businesses. The social and environmental impacts outlined in the above articles are certainly important, and will be reflected upon in the analysis of my research. However, these issues which are dominant in the existing literature will not be the central focus of this project, as explained above. Furthermore, the issues discussed by Wise and Mendoza (2001), Puyana and Moreno (2016), and Gutiérrez (2016) will be researched in greater depth in an attempt to offer conclusions regarding how Canadian mining investment has affected Mexico's economic development.

\section{Methodology}

I adopted a multi-method approach utilizing both empirical data collection analysis and in person interviews for this thesis project. The interview process provided very interesting and original findings which cannot been located in existing publications. However, the interviews were not recorded, and the participants often wished to remain anonymous. For these reasons it would have been difficult to base the project's entire analysis upon my qualitative findings which is why the empirical data collection process complemented the qualitative findings very well. Empirical data collection provided a solid basis of new knowledge which this thesis is providing to academia. The mining production statistics which were collected and analysed cannot be found in any other public source. In fact, the empirical data collection findings negate many of the contemporary suppositions about Canadian capital in Mexican mining, as will be demonstrated in the literature review and theoretical approaches sections. Utilising two different methods allowed for information found in each process to be verified by the other. 
This project is exclusively concerned with metallic mining because it is the only part of the mining industry that Canadian companies in Mexico are involved in. ${ }^{52}$ Therefore, an analysis of non-metallic mines would not be conducive to the research. Furthermore, $86 \%$ of the production value of all mining in Mexico in 2014 was derived from metallic minerals. ${ }^{53}$ For these reasons, I decided that focusing exclusively on metallic minerals with Canadian participation made the most sense considering this project's scope of analysis. In Mexico's case, the seven principal metals which are extracted by Canadian and non-Canadian companies are: gold, silver, copper, zinc, lead, iron ore, and molybdenum.

Quantitative Analysis: Production Data Collection and Analysis

The research project began with data collection of production figures for all metallic mines operating in Mexico for two reasons. First, it was decided that an analysis of production data would be a good starting point for the research because other publications addressing mining in Mexico had contradictory views about which companies dominate the sector. ${ }^{54}$ Authors who have written about Mexico's mining sector have largely focused their data on charts and graphs from Mexico's Secretary of the Economy, CAMIMEX, INEGI, and other sources which provide general mining information. These sources provide a general idea of Canadian participation in the sector, but the information is not exact, and it does not explain the historical progression of Canadian operations in Mexico in the twenty-first century. It should be pointed out that data collection for this research has found many issues with the information

\footnotetext{
52 The distinction is important because it narrows the project's analysis, with a specific scope that does not involve the extraction of other materials such as oil, gas, cement, quartz, precious stones, and other non-metallic minerals. 53 "Situación de la Minería en México en 2014" Reporte de Situación 2015, CAMIMEX, 11.

${ }^{54}$ For example, Tetreault (2014) argued that Canadian mining interests are dominating and imperialistic, while Guitiérrez (2013) argued that Mexican companies continue to have a monopoly in the mining sector.
} 
provided by INEGI and the mining administration sections of Secretary of the Economy. ${ }^{55}$ For example, a printed information booklet that is also available online lists six different mines as 'in production' in 2014, which remained in development at the time of writing, January $2015 .^{56}$ Accuracy in data analysis and an understanding of Canada's recent entry into the Mexican mining industry are necessary predeterminants in claiming an understanding of the effect of Canadian FDI on Mexico’s economic development. For the purpose of this paper, economic development is defined as an effort to improve economic well-being and quality of life by creating and/or retaining jobs, increasing incomes and augmenting the tax base.

Second, many authors that claim malevolence on the part of Canadian mining interests in Latin America tend to focus on capital investments in exploration, land concessions for exploration, and the number of Canadian companies exploring in a certain country. It is my contention that focusing on exploration data, rather than production data, can lead to the demonstration of exaggerated findings and inaccurate analysis. The majority of exploration properties and exploration investment will not result in a producing mine, and therefore it is difficult to make conclusions about economic development with these data. Nevertheless, many academics tend to focus on these data which inflate the appearance of a significant Canadian presence, especially in the case of Mexico, as will be demonstrated in the empirical findings section. It is likely that authors tend to use exploration data more often than production data because it is more accessible (in fact, this project presents the most complete data set on production statistics in Mexico that is currently available) and it better supports their arguments.

\footnotetext{
${ }^{55}$ In Spanish: Dirección General de Desarrollo Minera y Servicio Geológico Mexicano, both from the Secretary of the Economy

56 "Principales Minas y Proyectos Avanzados" demonstration in information folder, "La Minería es una Industria Comprometida con las Comunidades y el Medio Ambiente" from the Secretary of the Economy, Coordinación General de Minería, distributed October 2015.
} 
An analysis of exploration data can be useful for predicting future production trends in certain metals, as well as for gauging which countries firms believe to be the most economically beneficial in the near future. However, when attempting an investigation of the effect mining has on a country's economic development, analyzing producing mines provides a more accurate understanding than an analysis of exploration properties.

A 2007 UNCTAD World Investment report focused exclusively on TNCs, extractive industries and development. ${ }^{57}$ The report outlined the relationship between extractive TNCs and host countries, highlighting the most important economic development contributions made by the TNCs. The report helped me arrive at the decision that a thorough analysis of the effect of Canadian mining investment on Mexico's economic development must focus primarily on production data of all mines in Mexico. Analyzing mines that are in production allows one to understand the significance of: employment, each company's revenue, Mexican public revenue, how prices and policy affect mining investment, which metals are most important to the economy, the likely presence of value added products and services, as well as the majority of social and environmental implications. In addition, knowing the production output and value of each mine in Mexico throughout the past twenty years allows one to understand the importance of Canadian companies in the sector vis-à-vis Mexican and other international companies.

The data collection process began with collecting production information from www.infomine.com ${ }^{58}$ which provided a database with the majority of mines in production in

\footnotetext{
57 "World Investment Report: Transnational Corporations, Extractive Industries and Development" UNCTAD (2007): 1-323.

${ }^{58} \mathrm{www}$.infomine.com is an organization which compiles information about mines from around the world which is largely used by industry leaders. However, different sections of the webpage are designed for different groups of clients. The information is collected by infomine's management team of over 100 employees, which are located across a variety of important mining countries. For more information, visit: http://www.infomine.com/about/.
} 
Mexico in 2014. The following information was recorded from the website in an Excel spreadsheet: mine name, company name, the home country of the company, relevant subsidiary companies, when the mine was bought/began production, the type of mine (open-pit or underground), the state the mine is located in, the metals that are produced, and how much of each metal was produced (recorded either in pounds or tonnes). This information was logged in a different worksheet of the same Excel document for every year from 1996 (the year the Mexican Foreign Investment Law was signed) until 2014. For each year, two worksheets were created one displaying all the information of Canadian companies, and the other all the information of Mexican and all other non-Canadian companies. In some cases, the information was amalgamated in order to produce certain graphs and charts for analytical purposes. The Excel spreadsheet containing all empirical production data for this thesis project can be found in Appendix 1, "Base de Datos de Empresas Mineras en México"59.

In order to fact-check the information found on infomine, the same production data was located on other databases with Mexican mining information including: the CAMIMEX website, INEGI database, USGS reports, and the Secretary of the Economy website. Additional figures found on these databases were recorded in the Excel document. While checking these databases it became apparent that the production information from the infomine website was not always accurate; some mines were missing in their entirety, and information was not usually provided pre-2007.

In order to find pre-2007 data, and more accurate contemporary production information, annual and Merger \& Acquisition (M\&A) reports were located on company websites for exact

\footnotetext{
${ }^{59}$ See "Appendix 1: Mining Production in Mexico, 1996-2014" for the complete dataset that was created during this process.
} 
production figures. At this point I discovered that many company websites only provided reports dating back 5-7 years on average. In the case of Canadian companies, annual reports could be found on the SEDAR website, dating back to $1996 .{ }^{60}$ SEDAR is a filing system, which maintains an electronic record of economic reports of companies listed on the TSX and TSXV. In the case of non-Canadian companies, some of the pre-2007 data remains largely incomplete, as discussed in the limitations section. However, general information and total amounts of production (by year and by metal) could be located using other previously mentioned sources such as CAMIMEX and INEGI. This general information helped to fill in the gaps that were left by a lack of annual reports. I understand that the historical data used in this thesis could be more accurate. Nevertheless, the production data used in this project is the most extensive and up-todate of any academic analysis of the Mexican mining sector thus far to the best of my knowledge.

Using Bloomberg Institute terminals at the Carleton University library, metals prices were collected from the London Metal Exchange in Canadian dollars ${ }^{61}$ for each corresponding year. This data was entered into the Excel spreadsheet in order to calculate production values. Using excel formulas, totals were calculated for each mine, each company, each metal, and each home country both in terms of production outputs, as well as production values. This information provided me with a thorough understanding of how much Canadian companies earn compared to Mexican companies, where Canadian mines have been located, and what are the primary metals

\footnotetext{
60 "www.sedar.com is the official site that provides access to most public securities documents and information filed by issuers with the thirteen provincial and territorial securities regulatory authorities ("Canadian Securities Administrators" or "CSA") in the SEDAR filing system. The statutory objective in making public this filed information is to enhance investor awareness of the business and affairs of issuers and to promote confidence in the transparent operation of capital markets in Canada. Achieving this objective relies heavily on the provision of accurate information on market participants." Source: http://www.sedar.com/homepage_en.htm.

${ }^{61}$ All dollar figures in this thesis refer to Canadian dollars unless otherwise stated. The Bloomberg terminals allowed me to record metals prices in Canadian dollars with conversions agreeable to the dates of the prices.
} 
that Canadian companies extract. Charts and graphs were made using this information, which formed part of a "Preliminary Findings" document that also included corresponding industrial analyses and predictions. ${ }^{62}$ This document was sent in e-mails along with interview invitations in order to demonstrate to industrial leaders in the private and public sector that the research project is producing new information, and that the researcher understands the sector. Some of these graphs and charts have also been used in the empirical findings section of this thesis.

Company websites, annual reports and annual information sheets were used to collect data regarding the number of employees that each Canadian company had in Mexico in 2014. I decided against collecting the same information for non-Canadian mining companies in Mexico, because this project is not necessarily concerned with how those companies contribute to the country's economic development. Data was not collected for previous years, as I suspected that increases which I had already found in Canadian production since 1996 would naturally coincide with increases in employment. Furthermore, the benefits of collecting employment information of Canadian firms since 1996 would have been negligible compared to the time it would have taken to do so. I was able to uncover the number of employees at 39 of the 46 Canadian mines in production in 2014, which made up 95\% of Canadian production value that year. The total number of employees which I reference in the analysis section was calculated by adding $5 \%$ onto the total number of known employees. Therefore, the number of Mexican employees that Canadian mining firms hired in 2014 is not known with exact precision, but the figure is considered to be quite accurate.

\footnotetext{
${ }^{62}$ See "Appendix 1: Mining Production in Mexico, 1996-2014" to view the document which was sent to industry leaders.
} 
The main weakness in the data collection process was the unavailability and uncertainty of production data before 2008. For Canadian companies operating in Mexico pre-2008, it was possible to search their name on the SEDAR website (the solitary source of Canadian company's detailed historical information). However, since companies can only be searched by name on the SEDAR website, and not by sector, it is difficult to be certain that all relevant Canadian companies are in my database. The reason for this is that if there was a Canadian company producing metals in Mexico in the late 1990s or early 2000s, which terminated their operations before 2008, there is no known way to locate said company. However, data from the other sources I mentioned earlier confirm that the majority of Canadian production began post-2007, a few years after the commodity boom began. This means that although my data is incomplete for the first decade after the foreign investment law was signed in 1996, it is unlikely that unknown data would significantly affect the quality of my analysis.

Furthermore, a 'SEDAR website' equivalent does not exist in Mexico and therefore it was not possible to access historical production data of each Mexican mining company. Generally speaking, Mexican companies provide better online access to annual reports than Canadian companies, but the majority only date back to $2009 .{ }^{63}$ Collected information was verified using government and non-government sources (e.g. Chamber of Mining in Mexico CAMIMEX), Secretary of the Economy, and the Canadian Mining Task Force (CMTF) ${ }^{64}$ ) which provided total production numbers for each metal by year. This information allowed me to fact check my database as I was able to compare the totals of each company's production information to figures from other sources, and in nearly all cases the figures were very similar. Nevertheless,

\footnotetext{
${ }^{63}$ However, there are two small companies (one from the UK, the other Mexican) which I could not find any information on whatsoever.

${ }^{64}$ The CMTF is a branch of the Canadian Chamber of Commerce in Mexico that promotes Canadian mining interests in Mexico.
} 
it is important to reiterate that my data collection process suggested that the information provided by many of these well-respected institutions was often times inaccurate. The UNCTAD document which analysed TNC involvement in the extractive industries of developing countries provides an accurate description of the difficulties of collecting and interpreting FDI data and production figures ${ }^{65} \mathrm{I}$ believe that my data collection process exhausted all possible and reasonable avenues to ensure accurate production data were collected.

\section{Qualitative Analysis: Interviews ${ }^{66}$}

Interviews were utilized in this research project in order to enrich my understanding of the climate of the mining sector in Mexico. ${ }^{67}$ Interviews were also conducted in order to understand the opinion of industry leaders ${ }^{68}$ on various issues regarding how Canadian FDI affects Mexico's economic development. The information gathered from interviews with individuals working in the industry provided me with new ideas about Canada's role in Mexican mining, and how mining is perceived in different spheres of the trade. For example, an official from the Secretary of the Economy in the state of Zacatecas had a very different opinion than a Canadian mining firm representative about changes in mining taxation policy. These differences in opinion can translate into different sorts of efforts to support or block the installation of Mexico's new mining tax - actions that I found to have great significance. Obtaining different perspectives on the subject has provided the research with a diverse perspective and has helped in avoiding preordained biases. Business and government decisions that are recorded in official

\footnotetext{
65 "World Investment Report: Transnational Corporations, Extractive Industries and Development", UNCTAD: 101.

${ }^{66}$ See Appendix 3 for examples of some of the main interview questions that were used.

${ }^{67}$ I travelled to Mexico City and various mining regions from September-December 2015 in order to conduct interviews. All interviews with were conducted in Spanish, with the exception of two individuals: one Mexican who preferred to speak English, and a Canadian.

${ }^{68}$ I spoke with: financial directors and corporate relations directors of various Canadian mining firms, directors of municipal, state and federal level Mexican offices that are concerned with mining, the Auditor General's office, as well as Mexican and Canadian academics.
} 
documents are regarded as conventional forms of decision making. However, interviews showed that informal influences are also often salient, as demonstrated in the analysis section. Interviews were therefore also useful in bridging the formal-informal knowledge gap that was created by data collection and document analysis.

In the analysis section, which highlights the key findings gathered from interviews, information is also presented which was discovered at the XXXI International Mining Convention ${ }^{69}$ in October 2015. I decided that information from speeches, forums and debates from the conference should also be included in the findings, considering the relevance of the material and the importance of the individuals speaking there. The information that was captured at the conference is considered open, non-anonymous information because the individuals were speaking to a public audience.

Contact with interviewees was made through e-mail using my Carleton University e-mail account. E-mail addresses were collected from websites and documents of the respective organizations of the interviewees. The organizations with which successful contact was made and interviews were conducted include the following: a Mexican university, offices of various Canadian mining firms in Mexico, municipal offices where Canadian mining production occurs, one state and two federal level offices at the Secretary of the Economy, a former SHCP director, and the Auditor General's office. I believe that interviews conducted with the individuals from these institutions posed very little risk to their careers because the individuals had the option to remain anonymous, and much of the information they provided was common knowledge among industry insiders. Contact was also unsuccessfully attempted through e-mail with the following organizations: offices of Mexican mining firms, the CMTF, CAMIMEX, other academics, and

\footnotetext{
${ }^{69}$ In Spanish, 'XXXI Convención Internacional de Minería' which took place from October 7 - October 10, 2015 in Acapulco, Mexico.
} 
other Canadian mining firms. Clearance from Carleton's ethics committee was established before leaving Canada and arriving in Mexico to conduct interviews.

In the e-mails that were sent, the following information was included: my professional information, what the research project is attempting to discover, ethics procedures, a description of what the interview would consist of, and the Preliminary Findings document which was created using data analysis. In most cases, e-mails were unsuccessful in making meaningful contact with interview subjects. In these circumstances, phone calls were made to the office of the prospective interviewee, which was met with much greater success. Nevertheless, the e-mail process was a useful first step as the majority of the offices which were contacted by telephone remembered my e-mail, which provided somewhat of a legitimizing aspect to the phone call. Most interviewees were very satisfied with the data analysis document which was sent in the original e-mail. I believe that sending this document in the original interview request e-mail increased my legitimacy and aided the interview process substantially. It is likely that I would have been unsuccessful in speaking with Canadian mining firm representatives if they were not aware that I had already completed extensive research about the industry. In fact, many interviewees informed me that they had not seen the production information I presented to them at any point before. Other interviews were the result of contacts formerly created by colleagues. Face to face interviews were scheduled in Mexico City, Zacatecas and Guanajuato through email and telephone.

All interviews were conducted one-on-one between myself and the individual being interviewed, with two exceptions ${ }^{70}$. Most interviews occurred in the office of the individual

\footnotetext{
${ }^{70}$ The interview at the Municipality of Morelos was executed with the original interview subject, the Director of Economic Development, as well as the Municipal Secretary. The interview with the DGDM occurred with two individuals, one with a geological background who was my original contact, and the other an economist.
} 
being interviewed, except for two interviews which occurred at a café near the office of the interview subject. At the beginning of the interviews, oral consent was provided by the interviewee at which time the individual also stated if they wished the interview to be conducted in anonymity or openly. Following this, I described what the research project attempted to discover, and how the individual was contributing to the research process. At this point, I began with the interview questions.

Generally speaking, I began with simple questions about the mining industry in general, before moving on to more difficult and specific questions about the individual's organization. Basic research was conducted about the individual being interviewed, as well as the individual's organization, before arriving at the interview in order to best understand what types of questions to ask. Interview questions were prepared specifically for each interview subject beforehand, and an attempt was made to ask all questions that were prepared. An attempt was also made not to ask questions which would make the subject feel as if they were being attacked. This was important because if the interviewee felt like he or she was being criticized, it would likely be difficult to continue a productive interview. Finding a balance between asking provocative and useful questions, while not putting the interviewee on the defence, was an important strategy in the interview process.

Interviews were conducted in a semi-structured and open-ended format, meaning that if the interview subject began to speak about something that was not asked, the information could still be considered new and useful. In the majority of instances that the interviewee began to veer away from a specific question, the individual addressed a question that had been planned for later in the interview. Using a flexible interview methodology allowed interviews to take place with a more natural feel, which in turn likely produced better results as the interviewee felt comfortable 
speaking in a less formal, and more open manner. At no point did an interview subject request to skip a question. Almost every interview that was conducted lasted longer than the originally planned 30 minute timeline, and many lasted for more than an hour. This was considered a good sign as the interviewee did not feel threatened, and wished to provide as much information as possible to the research project.

An electronic recorder was not used in the interviews as it was believed that using such a device would limit the information provided by the interview subjects as a result of additional, unnecessary pressure. Since many of the interviews were conducted in anonymity, it was also not necessary to get quotes from interview subjects with a recording device. Instead, notes were hand written in Spanish during the interviews. Upon leaving the interview, I would go to a nearby location (e.g. a library or café) and write additional notes while the information was still fresh. I believe that all relevant information provided by interview subjects was captured in the note taking process. Therefore, the absence of an electronic recording device was seen as beneficial as it improved the 'natural conversation' setting of the interviews, and all relevant information was recorded manually.

One weakness of my interview methodology is that I focused exclusively on 'elite' individuals (e.g. policy makers, mining company representatives, embassy personnel). The interviews did not include individuals that work in the mines, live nearby mining territories, union leaders, NGOs, or other individuals that are affected by mining activity. My 'elitist' selection criteria for interviews occurred as a result of the project's interest in how government and private sector decisions affect Mexico's economic development, rather than the effect mining has on local populations. Interviews with a wider range of individuals would have been ideal, but did not occur as a result of time constraints. In a more general sense, my analysis is 
more concerned with the macro-level effect of Canadian mining on Mexico's economic development, rather than examining specific cases. Another weakness that is inherent to the interview process is that one can never be certain whether the information being relayed is truthful. However, giving interviewees the option to remain anonymous, and keeping questions focused on economic issues (rather than social and environmental issues), helped to remedy this concern. 


\section{Chapter 2}

\section{Theory and Canadian Mining:}

\section{High Time for a New Approach}

Throughout the past decade authors have used numerous theoretical approaches in order to examine operations and production in Canadian metal mining ${ }^{71}$ in Mexico. Their approaches have largely concentrated on social and environmental conflicts that are linked to Canadian mining operations in order to substantiate theoretical positions. The approaches that are commonly used in the contemporary setting may hold some weight when addressing Canadian mining in smaller and politically weaker states, such as Guatemala or Honduras. However, the "northern dominance" model is troublesome in the context of Mexican mining. Rather than revert to arguments surrounding academically saturated (yet important) environmental and social conflicts, I aim to shed some light on the impact Canadian mining may have on Mexico's economic development. The project's data analysis demonstrate that Canadian companies do not dominate mining in Mexico, suggesting that power is shared with other actors. The empirical section to follow demonstrates that these actors are comprised mainly of Mexican firms, but also include a few mining companies from other developing and developed countries. Interviews demonstrated that the most significant factor which hinders mining's contribution to economic development in Mexico is the weakness of various institutions in the country. This paper attempts to give agency and responsibility to Mexican institutions, while simultaneously maintaining an understanding of the importance of foreign influences.

\footnotetext{
${ }^{71}$ Metal mining is defined as the extraction of metals (e.g. gold, silver, copper, zinc, lead, iron ore, molybdenum) from the earth.
} 
The first part of this section will outline the principal theoretical approaches that have been used to understand Canada's relationship with mining in Mexico. It will also explore the dominant theoretical approaches used to describe the impact of mining in Latin America, in order to demonstrate contemporary understandings of extractivism used in the region. The second part will introduce the concepts of new institutional economics, and will describe how this theory can be used to enrich our understanding of how the mining industry, and Canada's relationship with it, can impact Mexico's economic development.

\section{Canadian Mining: The Prevailing Theories}

The past decade has witnessed an upsurge in theoretical debates regarding the effect of mining on social, political, and to a lesser extent, economic outcomes, in Latin America. The dominant theories emerged as a consequence of the commodity boom in the 2000s. The everincreasing price of metals during this period ${ }^{72}$ caused a major expansion of mining FDI in Latin American countries, as well as changes in the policy objectives of many Latin American states, including Mexico. This section will outline the dominant contemporary theories used to understand mining in Mexico and Latin America which include: neoliberalism, extractivist imperialism, reprimarization theory, neo-extractivism, and post-neoliberalism. I believe that all contemporary and relevant literature which theorizes about Mexican mining is included in this section. However, academic writing on mining in Mexico has been surprising limited, especially considering Mexico's economic significance in the industry. For this reason, theories which have been used to describe mining in Latin America, although not specifically applied to the Mexican case, will also be analysed. All theories will be analysed with a critical nature, and an attempt

\footnotetext{
${ }^{72}$ See 'Figure 2: Canadian Metal Mining Production in Mexico by Company' for a timeline of how metals increased during the commodity boom.
} 
will be made to explain why the theories do not fit the contemporary context of mining in Mexico.

Neoliberal theory is defined very differently depending on the author using the term. ${ }^{73}$ For the purpose of this paper, neoliberalism is defined as a political economic system aimed at opening up markets to free trade by reducing trade barriers and liberalizing economies. Two 1990s World Bank (WB) reports which discuss the implementation and reforms to Mexico's mining law provide a clear indication of neoliberal influence. In an attempt to "support the [Mexican] government's program to deregulate the mining sector" ${ }^{\text {"74 }}$ the WB reports list six principal objectives: open the sector to foreigners, make public mining reserves private, establish concession fees, reduce royalties and taxation, institutionalize the state as a regulator, and support small and medium sized mining companies. ${ }^{75}$ The goal of these objectives was to induce private investment and reduce the state's role in the mining sector, under the assumption that this would help the economy grow. The mining sector reforms laid out by the WB in these reports, and adopted by Mexico's Congress, are directly in line with the basic tenants of neoliberalism. The mining law, which adopted these changes in 1994, was separate from the foreign investment law and the signing of NAFTA, but all three initiatives could be considered separate parts of President Salinas' (1988-1994) neoliberal reforms. However, considering that nearly all state mining properties were sold prior to the implementation of NAFTA (1994) and the foreign

\footnotetext{
${ }^{73}$ Taylor Boas and Jordan Gans-morse, "Neoliberalism: From New Liberal Philosophy to Anti-Liberal Slogan", Studies in Comparative International Development 44.2 (2009): 140.

74 "Memorandum and Recommendation for a proposed \$200 million loan to the United Mexican States for Mining Sector Reconstruction”, World Bank, Report Number: P-5512-ME, May 1991: 2. http://wwwwds.worldbank.org/external/default/WDSContentServer/WDSP/IB/1991/05/30/000009265_3961001074548/Render ed/PDF/multi_page.pdf.

${ }^{75}$ Implementation Completion Report, World Bank, Report Number: 18856, December 1996: 6. http://wwwwds.worldbank.org/external/default/WDSContentServer/WDSP/IB/1999/08/15/000094946_99032505561818/Rend ered/PDF/multi_page.pdf.
} 
investment law (1996), private investment in the mining industry was limited to a very small Mexican elite with political and economic reach, as explained in the literature review. ${ }^{76}$

Neoliberalism helps to explain many aspects of Mexico’s economic policies outlined in the previous paragraph during the presidential tenures of De la Madrid (1982-1988) and Salinas (1988-1994). However, neoliberal theory calls for the opening of domestic markets to laissez faire international investment, which is not what happened in the case of metal mining in Mexico. Under these presidents, Mexico's state owned mining properties were sold at prices far below market value to an exclusive group of purely Mexican investors. ${ }^{77}$ One of the fundamental issues with neoliberal (and neoclassical) economics is the assumption of perfect knowledge and rational actors - two suppositions that new institutional economics (NIE) rejects, as explained in the following section. Neoliberal political objectives were unable to predict problems of nepotism, cronyism, and monopolies in Mexico's mining industry because of an unwillingness to consider political and institutional phenomena. As a result of these presidents' approaches, Mexico’s principle metal producers became (and continue to be) legacies of cronyism and closed-market neoliberal reforms.

As a response to previous state-led economic systems, neoliberalism was posited to induce economic growth and positive development outcomes through a market-led economy. Mexico's mining sector reforms of the 1990s provide a great example of how neoliberal policy was used to 'reconstruct' the country's economy. Contrary to what was anticipated, from 19832005 Mexico’s annual GDP growth rate averaged just 1.2\%, well below expected growth rates for middle income economies. ${ }^{78}$ Neoliberal theory can be used to help us understand the

\footnotetext{
76 Ibid: 115 .

77 Wise and Mendoza, "Minería, Estado y gran Capital en México": 112.

${ }^{78}$ Alicia Puyana and José Romero, "La Economia Mexicana después de Dos Decenias de Reformas", Comercio Exterior 57.16 (2007): 780.
} 
historical aspects, and some contemporary consequences, of Mexico's mining sector and the policy changes afoot in that period. However, in order to understand 'where neoliberalism went wrong' and what this means for today's world, I intend to use NIE theory. This theory provides a space to value certain aspects of neoliberalism (such as the importance of market transactions) yet at the same time allows one to appreciate the effect of seemingly non-economic influences (such as cultural norms) on the mining industry.

Extractivist Imperialism has become another dominant theory used to describe mining FDI from TNCs based in developed countries, such as Canada, as a result of the recent commodity boom. ${ }^{79}$ Gordon and Webber describe this type of imperialism as, "rooted in the logic of a socioeconomic system that is driven by the competitive pursuit of profit based on the exploitation of labour, and which is subsequently prone to over-accumulation." ${ }^{\prime 80}$

Two works by Tetreault focus on the 'imperialistic power' of Canadian mining companies in Mexico, and describe the resulting effects on labour, society, and the environment. ${ }^{81}$ In Tetreault's articles, it is argued that "free-market mining in Mexico has led to Mexican oligopoly control, Canadian imperialism and narco-mining" ${ }^{82}$ Drawing on Harvey's analysis of accumulation by dispossession ${ }^{83}$, Tetreault focuses on the labour, social and environmental consequences of Canadian mining in Mexico. ${ }^{84}$ Using Marx, Luxemburg and Harvey, the author

\footnotetext{
79 Henry Veltmeyer, "The Natural Resource Dynamics of Post-Neoliberalism in Latin America: New Developmentalism or Canadian Extractivist Imperialism?" Draft prepared for presentation and discussion at Global Capital and Global Rights workshop SFU-UBC (2012): 1-63, Petras and Veltmeyer (2007), Tetreault (2014), Yates and Baker (2014), Azamar and Ponce (2014), Gordon and Webber (2008), Deneault, A., \& Sacher (2012).

${ }^{80}$ Todd Gordon and Jeffrey Webber, "Imperialism and Resistance: Canadian Mining Companies in Latin America", Third World Quarterly 29.1 (2008): 66.

${ }^{81}$ Darcy Tetreault, "Resistance and Reform in Mexico's Mining Sector" chapter in Extractive Imperialism in the Americas: Capitalism's New Frontier (Boston: Brill, 2014): 194-233.

Darcy Tetreault, "Free Market Mining in Mexico", Critical Sociology (2014): 1-14.

${ }^{82}$ Ibid, Tetreault: 2.

${ }^{83}$ Accumulation by dispossession is defined by Harvey in "The 'new' Imperialism: Accumulation by Dispossession", Socialist Register 40 (2004) as: neoliberal capitalist policies which result in a centralization of wealth and power in the hands of a few by dispossessing the public of their wealth or land.

${ }^{84}$ David Harvey, “The 'new' Imperialism: Accumulation by Dispossession”, Socialist Register 40 (2004): 63-87.
} 
claims that Mexican labour is exploited under false conditions of "peace, property and equality" with open utilization of "force, fraud, oppression and looting" ${ }^{85}$ As mentioned in the literature review, Bocking (2013) also focused on labour relations of Canadian mining using the case study of a mine in Guerrero. Tetreault's analysis accurately describes that very little employment results from mine production in Mexico. ${ }^{86}$ However, this phenomenon is common in the mining industry across the globe, including in Canada. The author fails to examine other important aspects related to the economic development impact of mining such as public revenue, and different forms of value added products and services ${ }^{87}$ New technologies and open-pit mining styles will continue to reduce employment in metal mining as the industry expands, a point which I expand upon in the analysis section. For this reason, it is crucial that studies focusing on the development implications of mining provide a holistic economic understanding of the industry. Furthermore Tetreault, like Bocking, focuses his analysis primarily on the power of Canadian companies, which gives little to no agency to the Mexican institutions which permit such a relationship.

Tetreault's empirical analysis of Canadian mining in Mexico focuses extensively on data regarding Canadian companies with exploration concessions, rather than producing Canadian companies. For example, the article states that mining concessions (the majority Canadian) cover $28.6 \%$ of Mexico's territory. ${ }^{88}$ This data falsely implies that Canadian capital is 'taking over' Mexican territory, an issue which I will contest in the empirical section. It is important to outline the problems with the author's empirical approaches as it helps to explain how the author concluded the existence of Canadian imperialism. The majority of the authors cited in the

\footnotetext{
${ }^{85}$ Tetreault, "Free Market Mining in Mexico": 8.

86 Tetreault, "Resistance and Reform in Mexico’s Mining Sector": 213.

87 "Transnational Corporations, Extractive Industries and Development" UNCTAD 130-135.

${ }^{88}$ Tetreault, "Resistance and Reform in Mexico’s Mining Sector”: 201.
} 
preceding and following paragraphs frequently make these types of empirical errors when purporting a Canadian imperialistic presence in Mexico and other Latin American countries. My empirical findings sections first aims to demonstrate that Canadian imperialism in Mexico's mining sector does not exist in the ways in which these authors describe. Nullifying the Canadian imperialism argument is a crucial first step in moving forward with an analysis of economic development as it allows the researcher to focus on domestic, Mexican influences.

Harvey's accumulation by dispossession framework is also used by Azamar and Ponce (2014) and Garibay et. al (2001) to explain Canadian mining in Mexico ${ }^{89}$ While these authors do not explicitly make an accusation of a Canadian imperialism, their approach is similar to Tetreault's in that they attempt to blame community conflicts, environmental problems, and labour issues exclusively on Canadian stakeholders. The authors' empirical investigations also focus exclusively on concession rights, and provide no references to mining production or the dominant Mexican companies. The accumulation by dispossession framework allows the authors (Azamar and Ponce) to focus all attention on the foreign company, rather than adopting a domestic focus: “... natural resources are foreign property which causes the state to lose its capacity to make decisions regarding investment, prices, production levels and future growth in the country... because these companies make the decisions" ${ }^{90}$ Although Harvey's accumulation by dispossession does not directly address imperialism, it is necessary to include the arguments of Azamar and Ponce and Garibay et. al in order to provide an understanding of the overwhelming academic consensus on Canada-Mexico relations in the mining industry.

\footnotetext{
${ }^{89}$ Claudio Garibay et. al, "Unequal Partners, Unequal Exchange: Goldcorp, the Mexican State, and Campesino Dispossession at the Peñasquito Goldmine", Journal of Latin American Geography 10 (2011): 153-176. Aleida Azamar and José Ignacio Ponce, "Extractivismo y Desarrollo: los Recursos Minerales en México" Revista Problemas del Desarrollo, 179.45 (2014): 137-158.

${ }^{90}$ Ibid, Azamar and Ponce: 143 [translated by author] [emphasis added by author].
} 
It is possible that a Canadian mining imperialism theory could be useful for Latin American countries where Canadian mining FDI is indispensable to their development plan. However, this research project suggests that imperialism is not a solid framework for understanding Canadian mining FDI in Mexico. The mining industry has represented less than $5 \%$ of Mexican GDP and public revenue for more than two decades. ${ }^{91}$ Canadian political influence in Mexico City is also limited by Canada's small contribution to Mexican GDP, in all industries. Furthermore, a minority (only 40\%) of public revenue from the mining industry is derived from Canadian companies, significantly limiting Canadian authority. ${ }^{92}$ Finally, the recent implementation of large mining royalties in December 2014 also verified a lack of Canadian influence in Mexico City, as will be demonstrated in the empirical section. These circumstances imply a significant degree of national autonomy on the part of the Mexican state in the mining sector - not northern-driven imperialism.

Extractivist imperialism and 'accumulation by dispossession' are the only theoretical concepts that have been used to approach Canadian mining in Mexico that I am aware of. Other authors have written about Mexican mining in general, as pointed out in the literature review section, but these articles largely presented empirical findings, with minimal theoretical framework. Considering the great financial importance of the Canada-Mexico mining relationship ${ }^{93}$, it is troubling that no attempts have been made to use a theoretical approach to explain the economic outcomes of this relationship. While extractivist imperialism and 'accumulation by dispossession' make useful contributions to certain aspects of the economic development implications of mining (ie. employment and socio-environmental degradation), the

\footnotetext{
${ }^{91}$ Appendix 1: Mining Production in Mexico, 1996-2014.

92 Ibid.

${ }^{93}$ As explained in the Introduction, Mexico received more FDI than almost all other Latin American country in mining investment throughout the commodity boom, with the majority of this investment coming from Canada.
} 
theories are unable to approach other important economic issues. Furthermore, as discussed later in this thesis, authors who employ these theories frequently use misleading empirical data which distorts the reality of Canadian FDI in the mining industry.

As a result of the absence of alternative theoretical applications to the Mexican case, it is important to explore some of the perspectives that have been adopted to explore the development implications of the mining sector in other parts of Latin America. Reprimarization, New Extractivist and Post-neoliberalism theories are similar in that they analyse the modern, leftleaning governments of Latin America, which have become known as the 'pink tide'. ${ }^{94}$ These theories focus on leftist governments' attempts to promote the export of natural resources (most notably oil, gas, and metals) in order to increase government revenues for social and economic development purposes. Policy orientated towards these goals contrasts both with neoliberal policies (see above) and Import Substitution Industrialization (ISI) - the previous leftist approach to economic development in Latin America. ISI was an attempt to break out of the world division of labour in which Latin American countries specialized in raw materials, while importing manufactured goods from Europe and the United States. The policy attempted to establish domestic production facilities to manufacture goods which were formerly imported..$^{95}$ Contrastingly, the modern theories of Reprimarization, New Extractivist and Post-neoliberalism focus on primary sector growth, and are often friendly to foreign investment.

Reprimerization theory examines the return of left-leaning governments to focus policy on primary sector growth, rather than manufacturing. New extractivist theory analyzes the phenomenon of governments which focus on natural resource extraction, but demand that public

\footnotetext{
${ }^{94}$ A term used to describe the recent election of left-leaning governments across the Latin American region.

${ }^{95}$ Werner Baer "Import Substitution and Industrialization in Latin America: Experiences and Interpretations". Latin American Research Review 7.1 (1972): 96.
} 
revenues from mining rents be devoted to social and economic development. Similarly, postneoliberalism theory seeks to explain how 'pink tide' governments focus their economic policy on the same sectors as neoliberalism did, but aim to nationalize these industries and/or use the revenues for social and economic development. The three theories outlined here differ very little as they seek to explain the same phenomenon - how and why 'pink tide' governments began to focus on natural resource extraction. Many authors that write about reprimerization, new extractivism and post-neoliberalism critique the manner in which the theories have been applied by various Latin American countries. Common critiques include: lack of respect for indigenous territories, poor environmental regulations/enforcement, minimal nationalization and lower than anticipated government revenues. It should be noted that the focus on natural resource extraction by left-wing governments which gave birth to these theories is directly associated with high prices for primary goods, created by the commodity boom of the 2000 s.

These three related theories are frequently used to explain economic development as it relates to mining in contemporary Latin America. ${ }^{96}$ The theories may be useful in helping to identify some of the problems associated with an excessive reliance on extractivism to fund social policy. However, they fail to help explain the case of Canadian participation in metal mining in Mexico for a number of reasons. First, Mexico has consistently used rents from its oil industry for social development since the 1930s, long before the evolution of the Pink Tide and its associated theories. ${ }^{97}$ Second, Mexico did not adopt a 'new extractivist' policy involving high

\footnotetext{
${ }^{96}$ Hans-Jurgen Burchardt and Kristina Dietz, "Neo-Extractivism - A New Challenge for Development Theory from Latin America", Third World Quarterly 35.3 (2014): 468-486, Macdonald and Ruckert (2009), Gudynas, forthcoming (Pablo's book), Chomsky and Striffler (2014), Veltmeyer (2012), Renique (2013), Bebbington (2009), and others.

97 Alicia Puyana Mutis, "La Economía Petrolera en un Mercado Politizado y Global - Mexico y Colombia" (México: FLACSO México, 2015): 165.
} 
taxation until two years after the commodity boom ended, in January $2014 .{ }^{98}$ In fact, Mexico's mining laws and the taxation system associated with the industry remained constant from 19962014, throughout the emergence of the Pink Tide and the development of its related theories. ${ }^{99}$ Third, the Mexican state has made no indication of re-entering the metal mining market since the denationalization period following the debt crisis in the 1980s. Finally, throughout the evolution of the Pink Tide in Latin America, Mexico has consistently had a centre or right-of-centre government, rather than one that is clearly associated with the left wing. The variety of factors outlined here demonstrate that the mining industry in Mexico cannot be accurately examined with the reprimerization, neo-extractivism and post-neoliberalism theories.

Extractivist imperialism and accumulation through dispossession can be useful tools for examining social and environmental problems associated with the Canada-Mexico mining relationship from an exogenous perspective. However, it is necessary to question whether the dominant theoretical approaches are the most useful avenues for helping to solve and prevent socio-environmental conflicts. Furthermore, one must also query about other economic development consequences of mining (ex. government revenue, backward and forward linkages) which are not properly understood by these approaches. Authors that employ these theories to help understand mining in Mexico (eg. Tetreault, Bocking, Azamar and Ponce, and Garibay et al) tend to over score the influence of foreign, namely Canadian, mining firms. They occasionally draw attention to the weaknesses of Mexican institutions when describing the privatization process of the 1980s. However, their focus on the role of Mexican institutions

\footnotetext{
${ }^{98}$ In January 2014 a reform was made to taxation policies which significantly increased the amount mining companies would have to pay. These new rents are destined to a "Development Fund for Municipalities and States with Mining Activities".

${ }^{99}$ Servicio Geológico Mexico, Statistical Yearbook of the Mexico Mining 2012, 2013 edition, "Chapter 1: Summary of Basic Mining Indicators": 8.
} 
comes to a halt once Mexico's borders are opened to free trade in the 1990s. The theories have overwhelmingly focused on the power of Canadian firms in Mexico's mining sector ever since. Extractivist imperialism seems to imply that once Mexico liberalized its economy, all Mexican institutions became virtually void of power, influence and responsibility. This thesis recognizes that social, environmental and economic outcomes in the mining industry related to Canadian investment result from the actions of both Canadian and Mexican organizations. However, a nearly exclusive focus on Canadian companies has omitted the significance of Mexican institutions on Canadian investment in the mining industry.

\section{Giving Agency to Mexican Institutions: A New Theoretical Approach}

The central issue of... economic development is to account for the evolution of political and economic institutions that create an economic environment that induces increasing productivity. ${ }^{100}$ (Peter Klein)

This thesis will attempt to steer the conversation in a different direction. I will draw upon the insights of the new institutional economics, in order to understand the implications of an understudied aspect of the Mexican mining industry - the economic development consequences of Canadian FDI. I have decided to use NIE to approach Canadian mining production in Mexico because it provides space for a discussion on how Mexican institutions have impacted, and continue to impact, the country's economic development. Employing NIE will help to provide a new understanding of the power possessed by Mexico's cultural norms and formal rules alike. In doing so, it is hoped that a near-exclusive focus on the actions of Canadian mining firms and the Canadian government in discussions regarding Mexico's mining sector will be considered less relevant than it has been in the past. This section will outline the history and relevant theoretical

\footnotetext{
${ }^{100}$ Peter Klein, "New Institutional Economics” University of Georgia, (1999): 462.
} 
concepts of NIE. It will also discuss the contributions that NIE can make in recognising the economic development implications of foreign investment in mining in Mexico.

The term new institutional economics was first introduced by Williamson in 1975 on the first page of his book, "Markets and Hierarchies: Analysis and Antitrust Implications”. However, the roots of the theory are considered to date back to the discoveries of other economists such as Coase $(1937,1960)$, North (1973), and others. ${ }^{101}$ NIE is considered to be a multidisciplinary approach combining law, organization theory, political science, sociology, and anthropology but the theory's primary language remains economics. ${ }^{102}$ It has been used to provide recommendations to improve firms' efficiency, to explain the evolution of cultural norms, to create public policy, and to help understand economic development. NIE theorists concede that economic theory has always recognized that institutions matter. However, they believe that as neoclassical economic theory progressed throughout the twentieth century, microeconomics became increasingly abstract, and institutional phenomena received less attention. ${ }^{103}$ NIE differs from neo-classical economics because it does not make unrealistic assumptions regarding the various real factors that influence the market. For example, unlike neoclassical economics, NIE considers the effects of: a public institutional framework, imperfect knowledge, irrational choice, or the cost of transactions. ${ }^{104}$ As explained by Douglass North (1995):

The new institutional economics is an attempt to incorporate a theory of institutions into economics. However, in contrast to the many earlier attempts to overturn or replace neo-classical theory, the new institutional economics builds on, modifies and extends neo-classical theory to permit it to come to grips and deal with an entire range of issues heretofore beyond its ken. What it retains and builds on is the fundamental assumption of

\footnotetext{
${ }^{101}$ Rudolf Richter, “The New Institutional Economics: Its Start, its Meaning and its Prospects" European Business Organization Law Review 6 (2005): 163

102 Klein, "New Institutional Economics": 456.

${ }^{103}$ Richter, “The New Institutional Economics: Its Start, its Meaning and its Prospects”: 164.

104 Ibid: 164-175.
} 
scarcity and hence competition - the basis of the choice theoretic approach that underlies microeconomics. What it abandons is instrumental rationality - the assumption of neo-classical economics that has made it an institution-free theory. ${ }^{105}$

Reflecting on his earlier work, Coase reminds us that NIE is a response to how little microeconomics corresponds to the real world. Coase notes that traditional economics fails to consider that institutions also determine prices, independent of supply and demand. ${ }^{106}$ Based on this initial premise, Coase and Williamson maintain that institutions are designed for the sole purpose of reducing transaction costs, and that institutions which fail to do so will fail in a competitive market. Transaction cost analysis is probably considered to be the most important triumph for NIE, as it seeks to explain why seemingly inefficient institutions are necessary in capitalist society, as explained in the following paragraph. For Coase and Williamson, institutions are useful economic tools as they reduce the uncertainty of human interaction in an unpredictable world, thus making economic interactions more efficient for society at large. As globalization and technological advancements become further entrenched, fewer people are needed in the production stream, and more workers are needed with a focus on minimizing transaction costs. North also appreciates the growing relevance of transaction costs. He estimated that from 1900-1970 the number of production workers in the U.S. increased from 10 to 29 million, while the number of white collar workers (mostly transaction cost reducers) increased from 5-38 million. ${ }^{107}$ Indeed, in 2014 78\% of Canadian jobs were in service provision, rather than primary or secondary goods production. ${ }^{108}$ Therefore, the implications of institutional

\footnotetext{
${ }^{105}$ Douglass North, "New Institutional Economics and Third World Development": 17. [Emphasis added by author.]

${ }^{106}$ Ronald Coase, “The New Institutional Economics" American Economic Review 88.2 (1998): 72.

107 Ibid.

108 Statistics Canada, "Employment by Industry”, accessed at http://www.statcan.gc.ca/tables-tableaux/sumsom/101/cst01/econ40-eng.htm.
} 
analysis will be of increasing importance, assuming the world continues down a similar path of globalization and technological advancements. Some examples of basic transaction costs include: discovering prices, negotiating and enforcing contracts, discovering incentives, monitoring employees and the market, as well as performance evaluation. ${ }^{109}$

Coase uses the example of how a motorist (a private actor) interacts with traffic laws (a public institution) to explain how institutions reduce transaction costs for the whole of society. In his example, the motorist comes to a stop at a red traffic light, regardless of the complete absence of any other vehicle on the road. Even though it would be more efficient for the motorist to run the red light and reach his or her destination in a shorter amount of time, the motorist waits for the light to turn green in order to avoid a fine which was implemented to avoid accidents. ${ }^{110}$ The example shows that in some circumstances, the private product is worth less than the social product. Institutions, such as traffic laws, which seem to reduce economic efficiency for the individual cannot be explained by traditional economic theory and therefore must be incorporated into economics through transaction cost analysis. I contend that the implementation and enforcement of public policies to induce economic development in Mexico's metal mining sector could present a similar case. In Mexico recently implemented policies, such as royalties on mining production, reduce economic efficiency for the private actor but significantly improve public goods.

North also focuses extensively on transaction cost analysis, but contends that institutions have been created for something beyond improving economic efficiency. ${ }^{111}$ For example, institutions such as democracy and the family are necessary even within a theoretically perfectly

\footnotetext{
109 Klein, "New Institutional Economics": 464.

${ }^{110}$ Ronald Coase, "The Problem of Social Cost" The Journal of Land and Economics 3 (1960): 28.

${ }^{111}$ Richter, “The New Institutional Economics: Its Start, its Meaning and its Prospects”: 173.
} 
competitive market with zero transaction costs. This is because NIE recognises that neo-classical economics does not provide a solution to all economic and political situations, and instead it suggests that institutions are also relevant to these understandings. North also differs from Williamson and Coase as he pays more attention to the effect of NIE on economic development. North does so in order to understand why poor countries remain poor, and what has been wrong with the world's approaches at modernizing different economies in the recent past. For this reason, although a variety of NIE writers are referred to in this thesis, North's understanding of NIE is used as a base understanding of the theory, and is referenced most often.

For North, institutions are "humanly devised constraints that structure human interaction" which include: laws, regulations, conventions, norms of behaviour, and the enforcement of these entities. ${ }^{112}$ Within this understanding, organizations are groups of actors that form and affect institutions, which include: political parties, regulatory agencies, firms, unions, co-ops, churches, clubs, schools, etc. ${ }^{113}$ The interaction between (formal and informal) institutions and organizations are fundamental in transforming ailing economies into efficient ones. Politics are important in economic interactions as they determine the rules of the game and define economic interaction. ${ }^{114}$ However, one of North's most important policy suggestions is that one must take into account norms and belief systems (informal institutions) when creating new rules (formal institutions), as it is these phenomena that ultimately determine the effect of new policy. ${ }^{115}$ As collective learning happens distinctly within different cultures, the implementation of the same formal rule can have different effects in different societies. It is for this reason, North explains,

\footnotetext{
${ }^{112}$ Douglass North, "New Institutional Economics and Third World Development": 23.

${ }^{113}$ Ibid.

${ }^{114}$ Id: 26.

${ }^{115}$ Douglass North, "The Adam Smith Address: Economic Theory in a Dynamic Economic World", Business Economics 30.1 (1995): 10.
} 
that privatization does not solve poor economic performance. ${ }^{116}$ Policy-making must appreciate that today's decision making will affect the outcome of tomorrow's economic performance, but all policy changes are constrained by the evolution of belief systems and norms of yesterday's society.

Appreciating the importance of informal institutions in policy-making is crucial, especially considering the knowledge gaps and cultural differences that exist in economic interactions between organizations in countries with distinct levels of development. For this reason, formal political institutions have their limits. Formal rules (such as the implementation of a mining royalty) can change overnight, yet changing informal institutions (such as nepotism, corruption, collusion, and corporatism) takes time. ${ }^{117}$ Importantly, North notes that it is in fact the informal rules and norms that dictate political change and allow that political change to be accepted. ${ }^{118}$ Applying this framework to Mexico's mining industry means that even if formal institutions regarding employment, value added products and services or public revenue are changed, their effects will be limited because of informal institutions (such as societal norms), which change over time. However, I contend that moulding formal institutions, such as rules and laws, in such a way as to improve inefficient or unproductive informal institutions will allow entities such as societal norms to change more quickly.

The importance of institutions in development economics has been written about extensively since the birth of NIE in 1975. More recently, a historical approach to development economics by Acemoglu, Johnson and Robinson has attempted to use NIE to explain why some countries have institutions better suited for economic growth than others. The authors explain

\footnotetext{
116 Ibid: 11 .

117 Ibid: 26.

${ }^{118}$ Douglass North, "New Institutional Economics and Third World Development": 25.
} 
that low settler mortality is strongly correlated with the implementation of laws, institutions and the encouragement of investment during colonial times. ${ }^{119}$ Logarithmic analysis of these historical institutions was associated with a likely presence of effective institutions today, and higher GDP per capita. The author's argument is that higher European settler mortality in the $17^{\text {th }}$ and $18^{\text {th }}$ centuries is directly related to contemporary poverty in former colonies. ${ }^{120}$ The authors illustrate that NIE is by definition a historical economics theory, as previously noted by North. ${ }^{121}$ The work of these authors provides a noteworthy example of the importance of institutions in determining economic development, and the evolutionary application of theory in contemporary analysis.

Coase, North, Williamson and other NIE scholars contend that property rights are the most fundamental institution, upon which all other institutions are built. ${ }^{122}$ North believes that the ability for a society to develop "effective, low-cost enforcement of [property rights] contracts is the most important source" of economic development. ${ }^{123}$ North, Acemaglu and other authors give importance to property rights as they protect property expropriation by the government and other elites, and also help in avoiding nepotism on the part of the government. Further research should be undertaken in order to connect NIE's focus on property rights institutions, with NIE's understanding of the absence of perfect knowledge in economic transactions. This duality is important to Canadian mining in Mexico, as most social conflicts in the industry are rooted in

\footnotetext{
${ }^{119}$ Daron Acemoglu, Simon Johnson, and James Robinson, “The Colonial Origins of Development: An Empirical Investigation" The American Economic Review 91.5 (2001): 1391.

120 Ibid: 1369.

${ }^{121}$ Douglass North, "Structure and Performance: The Task of Economic History" Journal of Economic Literature 16.3 (1978): 965.

122 Richter, "The New Institutional Economics: Its Start, its Meaning and its Prospects": 172.

${ }^{123}$ Douglass North, "Institutions, Institutional Change and Economic Performance." (Cambridge: Cambridge University Press: 1990): 54. [Emphasis added by author.]
} 
low payments for communal lands where mines are developed. ${ }^{124}$ Reconsidering how property rights are managed in Mexico's mining regions could potentially have a very positive impact on the reduction of social conflicts between communities and mining companies.

In the analysis section a thorough understanding of how mining impacts employment and public revenue, as well as the potential effects of value added products and services, will be provided. NIE will be used to outline how formal and informal Mexican institutions have the power to take advantage of these economic development determinants. I plan to focus on the theory's understanding of why transaction costs exist (limited knowledge, imperfect predictions of future events, cultural gaps in global business, etc.) and what this teaches us about Mexico's mining relationship with Canada. The analysis will aim to explain why the character of Mexican institutions are more significant in explaining the limited contribution of mining to economic development than the role of foreign actors. Canadian companies certainly benefit from the weakness of some of Mexico's institutions, but neither they nor the Canadian government have the ability to 'change the rules of the game'. While action from the Canadian government and civil society is welcome in addressing the worst cases of Canadian corporate abuse, long-term change in Mexico's mining industry will be more effectively implemented by Mexican citizens and politicians. In short, NIE will be used to recognise the failure of Mexican institutions to serve its citizens in an attempt to supplement the problems outlined by other authors concerned with Canadian corporate behaviour. This redirection will focus primarily on economic development implications, rather than old discussions of social and environmental issues.

${ }^{124}$ Garibay et. al (2013), Garibay and Camacho (2011). 
Chapter 3

Canadian Mining Firms - 


\section{Important yet Minority Producers: Empirical Data Findings}

This section will present information that was gathered during the empirical data analysis process of Canadian mining production in Mexico. It will outline how the data has demonstrated the expansion of Canadian mining firms in Mexico, and what caused this growth. Understanding how and why Canadian investment grew rapidly in Mexico is a crucial first step to uncovering how Canadian capital could potentially affect Mexican economic development.

Data collection of production outputs of all participating firms in the Mexican mining industry has indicated that Canada indeed has a significant presence in metals production in Mexico, particularly since 2008. In Mexico, seven metals are regularly extracted which represent the majority of Mexico's mining production value. Data collection and analysis has therefore focused on these seven metals, which in 2014 represented the following amounts of total metal mining production value:

1. Gold (30\%)

2. Silver $(23.5 \%)$

3. Copper $(23.5 \%)$

4. Iron Ore $(9 \%)$

5. Zinc $(9 \%)$

6. Lead (3\%)

7. Molybdenum $(2 \%)^{125}$

\section{Canadian Entrance to the Market}

\footnotetext{
125 Appendix 1: Mining Production in Mexico, 1996-2014.
} 
Since the privatisation period of Mexican mining properties in the late 1980s, three Mexican mining companies (Industria Peñoles, Grupo México, and Minera Frisco) dominated metals production in Mexico. ${ }^{126}$ While their percentage of Mexico's total production value has diminished since Canadian firms entered the market, these three Mexican companies still consumed $43.4 \%$ of the market in $2014 .{ }^{127}$ Production data demonstrates that Canadian mining companies began to have a presence in Mexico as early as 1996, the year the Foreign Investment Law was signed. However, the data also indicate that mining companies based in Canada remained insignificant metal producers for another decade, until 2006. In the years leading up to 2006, it is estimated that between one and four fully owned Canadian mines existed in Mexico. ${ }^{128}$ Figure 1 demonstrates how the number of mines owned by Canadian companies grew very rapidly post-2006. It should be mentioned that a complete absence of mining royalties in the Mexican mining industry encouraged Canadian investors to favour Mexico over all other Latin American countries throughout the period displayed in Figure 1.

\section{Figure 1}

\footnotetext{
${ }^{126}$ Wise and Mendoza, "Minería, Estado y gran Capital en México": 118.

${ }^{127}$ Appendix 1: Mining Production in Mexico, 1996-2014.

${ }^{128}$ Ibid.
} 


\section{Canadian Mines in Mexico vs. Gold and Silver Prices}

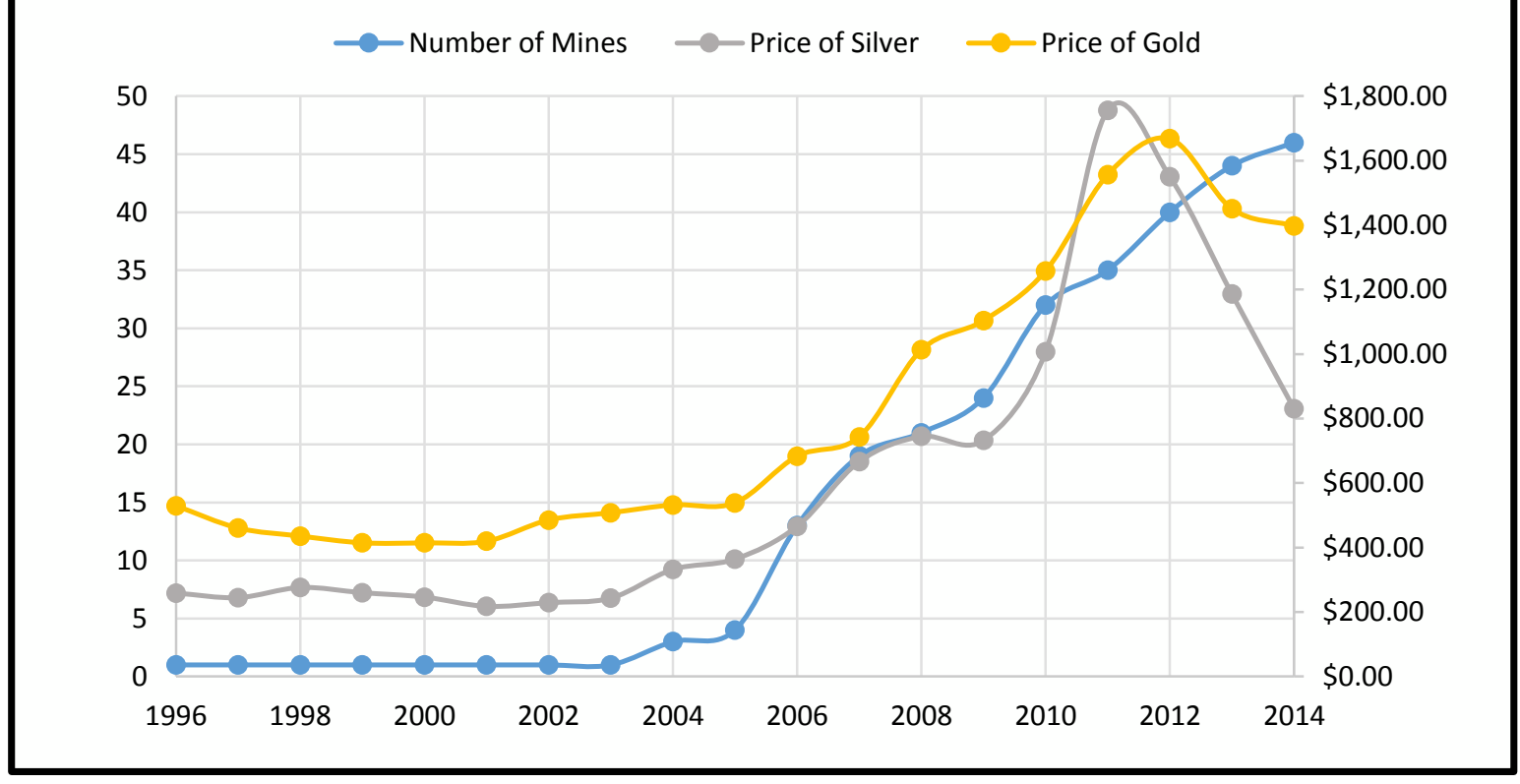

*The left axis represents the number of mines, while the right axis represents gold and silver prices expressed in Canadian Dollars (CAD) based on average annual prices from the London Metal Exchange (LME)

* Silver prices visualized at 40 times their actual value in order to provide consistency in the graph

The above graph serves to indicate not only the growth of Canadian owned mines, but

also that the progression was strongly associated with gold and silver prices. It illustrates that as gold and silver prices began to reach unprecedented levels in 2010-2012, Canadian mines became more common in the Mexican mining industry. It is necessary to mention that it is very common for a gold or silver mine to also extract other metals (in Mexico's case: copper, zinc, lead, or iron ore) as a result of the earth's geological composition. Nevertheless, a mine's principal metal can be determined with the calculation of production value of each associated mineral. The data indicated that of the forty-six producing Canadian mines in 2014, twenty-one were gold mines, twenty-one were silver mines, and four were copper mines, as demonstrated below in Figure 2. The production values of each metal in all Canadian mines in 2014 (displayed in Figure 2), as well as the historical information provided in Figure 1, demonstrate that Canadian mining operations in Mexico have chiefly been concerned with precious metals.

Although this finding has been suggested in other academic and industrial publications, accurate 
data collection showing the extent of the importance of silver and gold to Canadian companies has not yet been provided in the Mexican context. This discovery is very important because the extraction of precious metals can have a very different effect on various economic development indicators (e.g. value added processes, knowledge transfers, and in-country production) than industrial metals; a point which I will expand upon in the analysis section.

Figure 2 - Canadian Metal Mining Production in Mexico by Company ${ }^{129}$

\begin{tabular}{|c|c|c|c|c|c|}
\hline Country & Company & Mines & State & Commodity & $\begin{array}{l}\text { Total Production } \\
\text { Value }\end{array}$ \\
\hline \multirow{10}{*}{ Canada } & Goldcorp & $\begin{array}{l}\text { El Sauzal, Los Filos Bermejal, } \\
\text { Peñasquito }\end{array}$ & $\begin{array}{l}\text { Chihuahua, } \\
\text { Guerrero, } \\
\text { Zacatecas }\end{array}$ & $\begin{array}{l}\text { Gold, Silver, } \\
\text { Lead, Zinc }\end{array}$ & $\$ 2,338,807,487$ \\
\hline & $\begin{array}{l}\text { Pan } \\
\text { American } \\
\text { Silver }\end{array}$ & $\begin{array}{l}\text { Dolores, La Colorada, Alamo } \\
\text { Dorado }\end{array}$ & $\begin{array}{l}\text { Chihuahua, } \\
\text { Durango, } \\
\text { Sonora }\end{array}$ & $\begin{array}{l}\text { Gold, Silver, } \\
\text { Copper, } \\
\text { Lead, Zinc }\end{array}$ & $\$ 475,931,620$ \\
\hline & $\begin{array}{l}\text { Agnico } \\
\text { Eagle } \\
\text { Mines }\end{array}$ & Pinos Altos, La India / Tarachi & $\begin{array}{l}\text { Chihuahua, } \\
\text { Sonora }\end{array}$ & Silver, Gold & $\$ 378,426,522$ \\
\hline & $\begin{array}{l}\text { First } \\
\text { Majestic }\end{array}$ & $\begin{array}{l}\text { La Encantada, La Parrilla, San } \\
\text { Martin de Bolanos, La Guitarra, } \\
\text { Del Toro }\end{array}$ & $\begin{array}{l}\text { Coahuila, } \\
\text { Durango, } \\
\text { Jalisco, } \\
\text { México, } \\
\text { Zacatecas }\end{array}$ & $\begin{array}{l}\text { Silver, Gold, } \\
\text { Lead, Zinc }\end{array}$ & $\$ 351,219,597$ \\
\hline & $\begin{array}{l}\text { Primero } \\
\text { Mining }\end{array}$ & San Dimas & Durango & Gold, Silver & $\$ 321,947,500$ \\
\hline & $\begin{array}{l}\text { Endeavour } \\
\text { Silver }\end{array}$ & Guanacevi, Bolanitos, El Cubo & $\begin{array}{l}\text { Durango, } \\
\text { Guanajuato, } \\
\text { Guanajuato }\end{array}$ & Gold, Silver & $\$ 258,834,414$ \\
\hline & $\begin{array}{l}\text { Frontera } \\
\text { Copper } \\
(81 \%)\end{array}$ & Piedras Verdes & Sonora & Copper & $\$ 207,644,219$ \\
\hline & $\begin{array}{l}\text { Capstone } \\
\text { Mining }\end{array}$ & Cozamin & Zacatecas & $\begin{array}{l}\text { Silver, } \\
\text { Lead, } \\
\text { Copper, Zinc }\end{array}$ & $\$ 205,950,099$ \\
\hline & $\begin{array}{l}\text { Alamos } \\
\text { Gold }\end{array}$ & Mulatos & Sonora & Gold & $\$ 196,376,667$ \\
\hline & $\begin{array}{l}\text { Argonaut } \\
\text { Gold }\end{array}$ & El Castillo, La Colorada & $\begin{array}{l}\text { Durango, } \\
\text { Sonora }\end{array}$ & Gold, Silver & $\$ 190,972,692$ \\
\hline
\end{tabular}

\footnotetext{
${ }^{129}$ For more detailed information, including: year operations began, number of employees in each mine, relevant subsidiary companies, production (in ounces or tonnes) of each metal by each company, production (in CDN dollars) of each metal by each company, and the style of mine (open-pit of underground) please see Appendix 1 (email: cornelissensean@gmail.com). Also, all of the same information regarding Mexican and other non-Canadian mining companies is also included in Appendix 1. Finally, Appendix 1 contains all of the information explained here, dating back until 1996, with the exceptions and limitations outlined in the methodology section.
} 


\begin{tabular}{|c|c|c|c|c|c|}
\hline & $\begin{array}{l}\text { Timmins } \\
\text { Gold }\end{array}$ & San Francisco/La Chicharra & Sonora & Gold, Silver & $\$ 169,482,261$ \\
\hline & $\begin{array}{l}\text { Yamana } \\
\text { Gold }\end{array}$ & Mercedes & Sonora & Gold, Silver & $\$ 156,490,523$ \\
\hline & $\begin{array}{l}\text { Fortuna } \\
\text { Silver }\end{array}$ & San Jose & Oaxaca & Gold, Silver & $\$ 151,020,528$ \\
\hline & $\begin{array}{l}\text { New Gold } \\
\text { Inc. }\end{array}$ & Cerro San Pedro & $\begin{array}{l}\text { San Luis } \\
\text { Potosi }\end{array}$ & Gold, Silver & $\$ 123,296,828$ \\
\hline & $\begin{array}{l}\text { AuRico } \\
\text { Gold }\end{array}$ & El Chanate & Sonora & Gold & $\$ 94,037,169$ \\
\hline & $\begin{array}{l}\text { Sierra } \\
\text { Minerals }\end{array}$ & Cusi, Bolivar/Val & $\begin{array}{l}\text { Chihuahua, } \\
\text { Chihuahua }\end{array}$ & $\begin{array}{l}\text { Copper, } \\
\text { Silver, Zinc, } \\
\text { Lead, Gold }\end{array}$ & $\$ 82,939,810$ \\
\hline & Aurcana & La Negra & Queretaro & $\begin{array}{l}\text { Silver, } \\
\text { Copper, } \\
\text { Lead, Zinc }\end{array}$ & $\$ 80,612,209$ \\
\hline & $\begin{array}{l}\text { Great } \\
\text { Panther } \\
\text { Silver }\end{array}$ & $\begin{array}{l}\text { Topía, Guanajuato Production } \\
\text { Complex }\end{array}$ & $\begin{array}{l}\text { Durango, } \\
\text { Guanajuato }\end{array}$ & $\begin{array}{l}\text { Silver, Gold, } \\
\text { Lead, Zinc }\end{array}$ & $\$ 70,694,457$ \\
\hline & $\begin{array}{l}\text { Silvercrest } \\
\text { Mines Inc. }\end{array}$ & Santa Elena & Sonora & Gold, Silver & $\$ 66,008,043$ \\
\hline Canada & $\begin{array}{l}\text { Aura } \\
\text { Minerals }\end{array}$ & Aranzazu & Zacatecas & $\begin{array}{l}\text { Gold, } \\
\text { Copper, } \\
\text { Silver }\end{array}$ & $\$ 60,198,373$ \\
\hline & $\begin{array}{l}\text { Avino } \\
\text { Silver and } \\
\text { Gold } \\
\text { Mines }\end{array}$ & Avino & Durango & Gold, Silver & $\$ 57,897,075$ \\
\hline & $\begin{array}{l}\text { McEwen } \\
\text { Mining }\end{array}$ & El Gallo & Sinaloa & Gold, Silver & $\$ 54,022,977$ \\
\hline & $\begin{array}{l}\text { Scorpio } \\
\text { Mining }\end{array}$ & Nuestra Senora & Sinaloa & $\begin{array}{l}\text { Lead, } \\
\text { Copper, } \\
\text { Zinc, Silver }\end{array}$ & $\$ 52,358,748$ \\
\hline & $\begin{array}{l}\text { Excellon } \\
\text { Resources }\end{array}$ & Platosa & Durango & $\begin{array}{l}\text { Lead, Silver, } \\
\text { Zinc }\end{array}$ & $\$ 46,436,979$ \\
\hline & $\begin{array}{l}\text { Starcore } \\
\text { Internation } \\
\text { al Mines }\end{array}$ & San Martin & Queretaro & Gold, Silver & $\$ 33,747,421$ \\
\hline & $\begin{array}{l}\text { NWM } \\
\text { Mining }\end{array}$ & Lluvia de Oro & Sonora & Gold & $\$ 25,793,132$ \\
\hline & $\begin{array}{l}\text { ImpactSilv } \\
\text { er }\end{array}$ & Guadalupe Production Centre & Mexico & $\begin{array}{l}\text { Silver, Gold, } \\
\text { Lead, } \\
\text { Copper, Zinc }\end{array}$ & $\$ 18,582,196$ \\
\hline & $\begin{array}{l}\text { Marlin } \\
\text { Gold } \\
\text { Mining }\end{array}$ & La Nueva Trinidad & Sinaloa & Gold & $\$ 12,774,966$ \\
\hline & $\begin{array}{l}\text { Rochester } \\
\text { Resources }\end{array}$ & Mina Real & Nayarit & Gold, Silver & $\$ 8,631,598$ \\
\hline & Goldgroup & Cerro Prieto & Sonora & Gold, Silver & $\$ 6,834,747$ \\
\hline Canada & $\begin{array}{l}\text { GoGold } \\
\text { Resources }\end{array}$ & Parral Tailings Project & Chihuahua & Gold, Silver & $\$ 2,803,653$ \\
\hline & $\begin{array}{l}\text { Red Tiger } \\
\text { Mining }\end{array}$ & San Antonio & Sonora & Copper & $\$ 19,597$ \\
\hline
\end{tabular}




\begin{tabular}{|c|c|c|c|c|c|}
\hline \multirow{4}{*}{ Mexico } & $\begin{array}{l}\text { Grupo } \\
\text { México }\end{array}$ & $\begin{array}{l}\text { Buenavista, Charcas, IMMSA, } \\
\text { La Caridad, Santa Barbara, } \\
\text { Santa Eulalia }\end{array}$ & $\begin{array}{l}\text { Sonora, San } \\
\text { Luis Potosí, } \\
\text { Chihuahua }\end{array}$ & $\begin{array}{l}\text { Gold, Silver, } \\
\text { Copper, } \\
\text { Zinc, Lead, } \\
\text { Molybdenu } \\
\text { m }\end{array}$ & $\$ 3,559,723,563$ \\
\hline & $\begin{array}{l}\text { Industria } \\
\text { Peñoles }\end{array}$ & $\begin{array}{l}\text { Bismark, Cienega, Francisco I. } \\
\text { Madero, Fresnillo, Heradura, } \\
\text { Milpillas, Naica, Noche Buena, } \\
\text { Sabinas, Saucito, Tizapa (51\%), } \\
\text { Soledad, Velardeña }\end{array}$ & $\begin{array}{l}\text { Chihuahua, } \\
\text { Durango, } \\
\text { Sonora, } \\
\text { Zacatecas }\end{array}$ & $\begin{array}{l}\text { Gold, Silver, } \\
\text { Copper, } \\
\text { Lead, Zinc }\end{array}$ & $\$ 3,149,963,283$ \\
\hline & $\begin{array}{l}\text { Minera } \\
\text { Frisco }\end{array}$ & $\begin{array}{l}\text { El Concheno, Minera María, } \\
\text { Ocampo, Porvenir, El Colonel, } \\
\text { Asientos, San Felipe, San } \\
\text { Francisco del Oro, Tayahua }\end{array}$ & $\begin{array}{l}\text { Aguascalient } \\
\text { es, Baja } \\
\text { California, } \\
\text { Chihuahua, } \\
\text { Coahuila, } \\
\text { Sonora, } \\
\text { Zacatecas }\end{array}$ & $\begin{array}{l}\text { Gold, Silver, } \\
\text { Copper, } \\
\text { Zinc, Lead, } \\
\text { Molybdenu } \\
\text { m }\end{array}$ & $\$ 1,180,151,657$ \\
\hline & $\begin{array}{l}\text { Altos } \\
\text { Hornos de } \\
\text { México } \\
\end{array}$ & $\begin{array}{l}\text { Cerro De Mercado, Hercules, } \\
\text { Manzanillo }\end{array}$ & $\begin{array}{l}\text { Durango, } \\
\text { Coahuila, } \\
\text { Manzanillo }\end{array}$ & Iron Ore & $\$ 450,864,800$ \\
\hline India & $\begin{array}{l}\text { ArcelorMit } \\
\text { tal }\end{array}$ & $\begin{array}{l}\text { El Volcán, Las Truchas, Pena } \\
\text { Colorada }(50 \%)\end{array}$ & $\begin{array}{l}\text { Michoacán, } \\
\text { Sonora }\end{array}$ & Iron Ore & $\$ 699,802,000$ \\
\hline \multirow[t]{2}{*}{ USA } & $\begin{array}{l}\text { Gold } \\
\text { Resource }\end{array}$ & El Aguíla & Oaxaca & $\begin{array}{l}\text { Gold, Silver, } \\
\text { Copper, } \\
\text { Zinc, Lead }\end{array}$ & $\$ 177,119,261$ \\
\hline & $\begin{array}{l}\text { Coeur } \\
\text { Mining }\end{array}$ & Palmarejo & Chihuahua & Gold, Silver & $\$ 276,574,522$ \\
\hline Argentina & Ternium & $\begin{array}{l}\text { Alquila - Encinas, Pena } \\
\text { Colorada }(50 \%)\end{array}$ & Michoacán & Iron Ore & $\$ 385,585,560$ \\
\hline \multirow{2}{*}{ Japan } & Sumitomo & Tizapa $(10 \%)$ & Chihuahua & $\begin{array}{l}\text { Copper, } \\
\text { Gold, Lead, } \\
\text { Silver, Zinc } \\
\end{array}$ & $\$ 16,519,340$ \\
\hline & $\begin{array}{l}\text { Dowa } \\
\text { Mining }\end{array}$ & Tizapa $(39 \%)$ & Chihuahua & $\begin{array}{l}\text { Copper, } \\
\text { Gold, Lead, } \\
\text { Silver, Zinc }\end{array}$ & $\$ 64,425,427$ \\
\hline \multicolumn{5}{|c|}{ Total Production Value: } & $\$ 15,902,392,862$ \\
\hline \multicolumn{5}{|c|}{ Total Canadian Owned Production Value: } & $\$ 6,300,794,109$ \\
\hline \multicolumn{5}{|c|}{ Total Mexican Owned Production Value: } & $\$ 7,981,572,643$ \\
\hline \multicolumn{5}{|c|}{ Total Other Foreign Companies Production Value: } & $\$ 1,620,026,110$ \\
\hline \multicolumn{5}{|c|}{ Canadian Market Share: } & $39.6 \%$ \\
\hline \multicolumn{5}{|c|}{ Mexican Market Share: } & $50.2 \%$ \\
\hline \multicolumn{5}{|c|}{ Other Foreign Companies Market Share: } & $10.2 \%$ \\
\hline
\end{tabular}

Figure 1 demonstrates that although silver and gold prices began to rise post-2001 at the beginning of the commodity boom, the presence of Canadian mines did not significantly rise for another five years. The reason for this phenomenon is that developing an exploration property 
into a producing mine is a lengthy process, requiring large sums of capital investment, legal

proceedings and industrial administration. ${ }^{130}$ As a result of the bull market enjoyed by precious metals for nearly a decade, Canadian investors aggressively explored and developed mining properties across Mexico in order to take advantage of the high prices. As the value of gold and silver began to decline, many properties with high amounts of capital investment were already in advanced stages of development when prices began to fall post-2012. This helps to explain why the number of mines continued to grow from 2012 to 2014, despite falling prices. The capital and time invested to develop a mine could also provide insight into the timing of significant tax increases by the Mexican government in 2014, after major investments were already installed. The reasons for the new taxation will be discussed in greater detail in the analysis section.

\section{The Real Economic Significance of Canadian Mining FDI}

The encouragement that Canadian investors received from rising metal prices and the absence of mining royalties in Mexico caused the market share of Canadian companies to grow during the commodity boom. In 2006, companies based in Canada were responsible for just $7.7 \%$ of the value of production of metal mining in Mexico. As demonstrated in Figure 3, market share owned by Canadian companies gradually began to rise to a peak of $40.2 \%$ in 2012 . Attaining over one third of the value of Mexico's mining production in less than a decade indicates that Canadian mining interests were indeed very interested in the Mexican market. The most recent data collected for this research project indicates that Canadian companies earned roughly $\$ 6.3$ billion CDN in revenue in 2014, which represented 38.3\% of the Mexican metal mining market. This figure starkly contrasts with Canada's $68 \%$ majority share of mining

${ }^{130}$ UNCTAD, "World Investment Report 2007”: 94. 
investment in 2014, which is why it was important to research production figures. ${ }^{131}$ The reason for the disparity between the Canadian share of investment and production is that Mexican companies were already established in the majority of large and profitable mines before the commodity boom began. As a result, Canadian companies invest much more than Mexican companies, yet continue to produce less metals. In 2014, Mexican companies produced slightly more than $\$ 8.3$ billion worth of metals, representing $50.6 \%$ of the market. The remaining $11.1 \%$ of the market was made up by a combination of companies from India, Argentina, United States, United Kingdom and Japan, as demonstrated in Figure 2.

\section{$\underline{\text { Figure } 3}$}

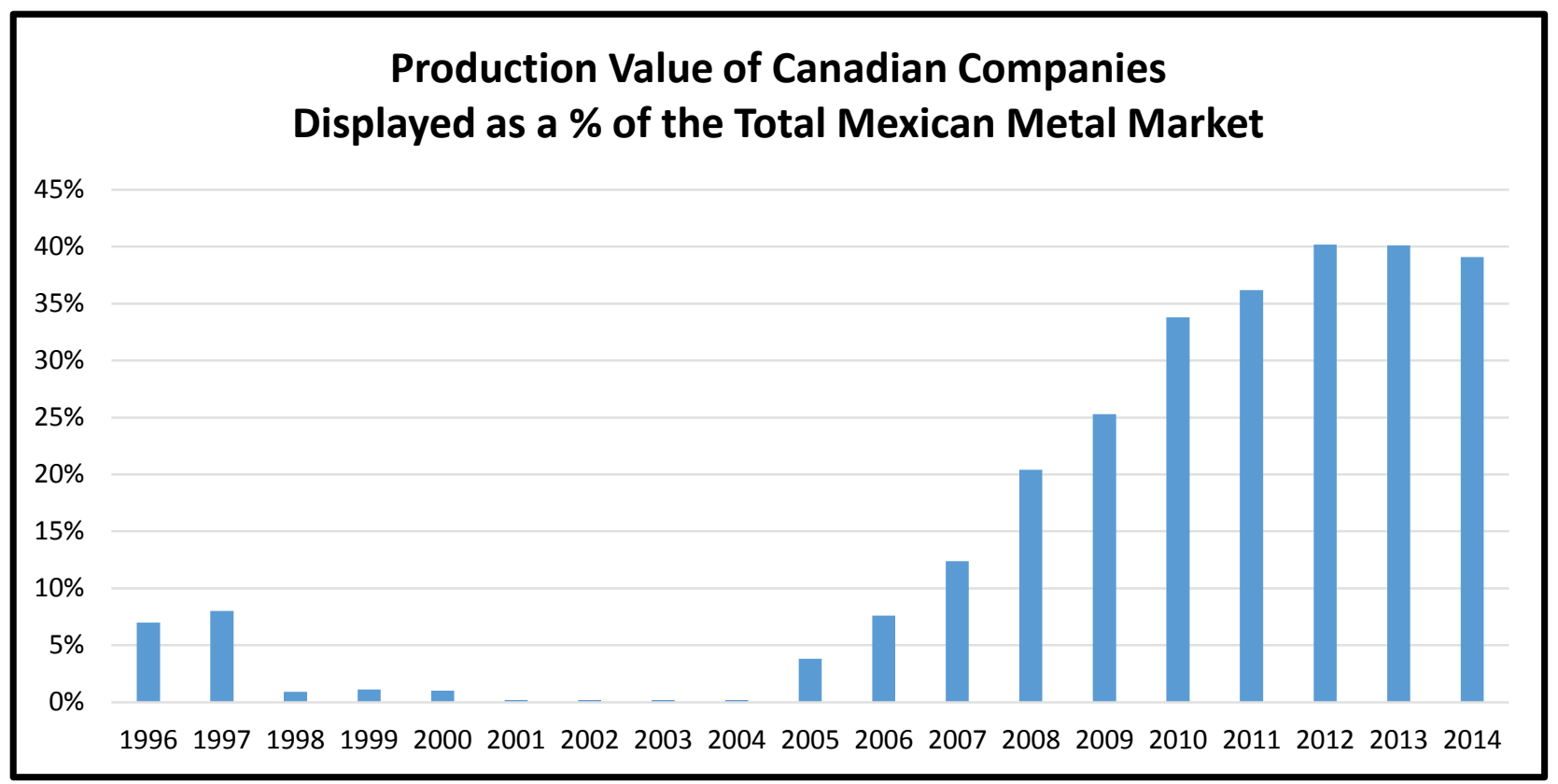

As will be further explored in the analysis section, these data illustrate that Mexican companies no longer enjoy a monopoly in the mining sector. They also undermine claims of the existence of a Canadian mining imperialism in Mexico. Both of these findings are very important

\footnotetext{
131 “Empresas con Capital Extranjera en México" in Prontuario: Industria Minero Metalúrgica, Dirección General
} de Desarrollo Minero, September 2015. 
because they demonstrate a more accurate assessment of Canadian investment in Mexico. Understanding how important Canadian mining companies are in the Mexican mining industry is a necessary first step in understanding their potential to contribute to Mexico's economic development.

Figure 3 demonstrates that of the 85 mines in production in Mexico in 2014, 46 mines were owned and operated by companies based in Canada. It also shows that of the 43 mining companies with production output in Mexico, 31 of these firms were based in Canada. Therefore, the data collected for this research indicate that Canadian companies far outnumber the number of companies from Mexico and other participating countries (72\%), and they also own the majority of producing mines in Mexico (54\%). At face value, these numbers seem to support the argument that Canadian companies dominate mining in Mexico. Nevertheless, the large amount of producing mining properties owned by a variety of Canadian companies generated less than $40 \%$ of total mining revenues in 2014 , as demonstrated in Figure 2. This means that even though Canadian companies own the majority of mines, they are less economically important than Mexican companies.

This finding is very important not only because it demonstrates where some of the myths of Canadian mining domination originate from, but also because it sheds some light on the nature of producing Canadian firms in Mexico. Further research into each of the Canadian companies in Figure 3 showed that the majority of these firms are very small and often operate exclusively in Mexico, with one solitary mine. Indeed, only 8 of the 31 Canadian companies are in possession of more than one producing mine in Mexico. The majority of the remaining 23 firms do not have operations outside of Mexico. As will be further explained in the analysis section, small and junior mining companies typically have less experience in the international mining industry and 
as a result often appear to be more reckless and less culturally aware of local norms. The size and maturity of Canadian firms participating in mining in Mexico is a very important factor to consider when analysing the effect of Canadian firms on Mexico's economic development. The information provided by my quantitative analysis suggests that many Canadian firms are very concerned about their investments in Mexico, however their influence is restricted by their limited production outputs, relative to Mexican companies. This phenomena will be discussed further in the next chapter.

\section{Geographical Implications of Canadian Mining}

In order to understand the economic impact of Canadian mining operations, it is important to clarify the importance of geographical factors in mining development. Mexico is a very large country, and is very geologically rich in metallic minerals. The dispersion of mineralrich mining regions throughout Mexico is a very important factor to consider when assessing mining's impact on economic development. This dispersion has led junior Canadian companies to venture to regions previously untouched by industrial mining. The fact that the majority of Canadian mines are located in northern states is also significant because of the area's desert landscape, and the role played by violent criminal gangs in this region, as explained below.

Analysing the location of Canadian mines across Mexico is a useful exercise as geography has important implications for mining's impact on economic development. Potential direct and indirect economic impacts related to geography which will be explored in greater detail in the analysis section include the following: infrastructure development, social and environmental degradation, employment and local government revenues. Since the largest developed mining properties were sold to Mexican companies before NAFTA and the Foreign Investment Law were signed, Canadian companies have explored in new regions, often with 
little historical connection to mining. The producing mines owned by Canadian companies were not developed, or often times even explored, by the Mexican state or the big three Mexican companies as a result of their lower reserves and extraction profitability. Higher prices resulting from the commodity boom of the 2000s made new properties profitable ventures for junior Canadian companies.

Indeed, in 2014 the average Mexican owned mine had a production value of \$285 million while the average Canadian mine had a production value of $\$ 137$ million; less than half of their Mexican colleagues. The most significant factor resulting from the location of Canadian mines is that they are often new mines, located in areas without a cultural history related to mining, or foreign influence. Many Canadian mines are located in states with a mining history such as San Luis Potosí or Sonora. However, local ejido populations in certain parts of 'mining states' (where Canadian mines have been developed) often do not have a historical, or cultural, connection to mining. Mines owned by Mexican companies, on the other hand, are largely located in areas with a social history related to mining. Most of these mines have been operating since before the 1990s, when mines were state owned and formed an important part of the PRI's corporatist system of governance. ${ }^{132}$ This finding is very significant as it helps to explain why Canadian firms are perceived to be socially and environmentally intrusive in Mexico, even though they produce less metals than Mexican companies. The fact that Canadian companies operating in new locations are usually small and inexperienced firms contributes to this phenomenon as the firms are often unaware of, or unwilling to understand, local cultural norms. Formal Mexican institutions should predict and attempt to prevent clashes between local populations and

\footnotetext{
132 Judith Teichman, "Economic Restructuring, State-Labor Relations, and the Transformation of Mexican Corporatism" chapter in Neoliberalism Revisited: Economic Restructuring and Mexico's Political Failure edited by Gerardo Otero, (Westview Press, 1996: Colorado): 149-167.
} 
Canadian mining firms, especially considering the recent history outlining consistent issues in these areas. I will expand upon the implications that inexperienced Canadian junior mining companies have in Mexico in the analysis section.

Of the 46 mines owned and operated by Canadian companies, 37 are located in northern states, which is significant for a number of reasons. First, many of these states such as Sinaloa, Sonora, and Chihuahua are strongly impacted by the presence of narco-traffickers, which has economic implications affecting the mining industry and regional development. For example, in April 2015 over $\$ 8$ million in gold was stolen from the El Gallo mine in Sinaloa, owned by McEwan Resources (a Canadian company). ${ }^{133}$ Shortly after the incident the company's owner, Mr. McEwan, told the Wall Street Journal that he now had to "ask for permission" from local gangs to continue operating. ${ }^{134}$ To underline the seriousness of this situation, in June 2015 Óscar Fitch Tovarand, the owner of Grupo Minero Panuco (a Mexican company) and his two sons were assassinated by local gang members. ${ }^{135}$ The violent situation in which many of Mexico's most economically significant mining states find themselves has likely affected the activities and security of Canadian firms and their employees. The situation speaks directly to the institutional weaknesses present in Mexico, and has resulted in at least one Canadian company having to "ask for permission" from violent criminal groups to operate in the area. The geographic location of many Canadian mines in northern states strongly associated with organized crime directly impacts these firms' ability to contribute to local economic development. ${ }^{136}$

\footnotetext{
133 "McEwen Mining says armed robbers stole 7,000 ounces of gold from their Mexican mine", CBC News online, by Pete Evans, April 8, 2015, http://www.cbc.ca/news/business/mcewen-mining-says-armed-robbers-stole-7-000ounces-of-gold-from-their-mexican-mine-1.3024579, accessed February 15, 2016.

${ }^{134}$ Ibid.

135 "Asesinan a familia minera en Pánuco", Noreste News online, June 26, 2015, http://www.noroeste.com.mx/publicaciones.php?id=1038693, accessed February 15, 2015.

136 Tetreault (2013) makes reference to narco-mining and its relationship with Canadian firms. However no literature can be found regarding the specific relationship between narco-traffickers, mining, and development.
} 
Secondly, northern Mexican states are also characterized by a desert landscape which makes environmental impacts somewhat easier to control than mining operations in an ecologically diverse region such as the Amazon. However, mining operations in remote and arid areas also have implications for local populations in regards to competition for resources such as electricity and water. ${ }^{137}$ Indeed, one of the issues surrounding the 2009 demonstrations at Goldcorp's Peñasquito mine in Zacatecas was the drying up of local water wells. ${ }^{138}$

Finally, the geological location of mineral riches in Mexico has attracted Canadian investment to remote areas with little other industry. This investment could potentially provide employment in areas where locals have few other options, as will be discussed further in the analysis. Infrastructure developments (eg. roads, power plants, sewage systems) in isolated areas also allow for mining to have a positive impact in the area for the growth of other industries. However, because Canadian mines in Mexico are so isolated, infrastructure improvements would only benefit a small amount of community dwellers nearby, if anyone at all. The relevance of all of the geographical implications cited in this section (Canadian mines being developed in 'new' areas, the violence associated with northern states, and the desert landscape) will be further explored in the analysis section.

\footnotetext{
${ }^{137}$ UNCTAD, “World Investment Report 2007”: 150.

${ }^{138}$ Garibay et al., "Unequal Partners, Unequal Exchange": 162.
} 


\section{Chapter 4}

Analysis:

\section{The Marginal Effect of Canadian Mining Firm's on Mexico's Economic Development}

In the previous chapter I presented quantitative findings which indicate that Canadian firms owned $38.3 \%$ of the 2014 metal mining production value, while Mexican firms controlled $50.6 \%$. These data demonstrate that as a result of Canadian investment during the commodity boom of the 2000s, Mexican mining companies (the majority of which are very large) no longer have a monopoly in the industry. The significance of this phenomenon is that Canadian capital is now a major player in Mexico's natural resource industry, which raises important questions about Canada's role in the country's economic development. This chapter aims to identify how the mining industry affects Mexico's economic development and what Canada's role is in that process. First, it attempts to identify if Canadian mining investment has significantly affected Mexico's economic development. Second, in cases where it becomes evident that Canadian mining firms have not significantly supported economic development, the chapter attempts to identify why that has not been the case. Drawing on information gathered from my database analysis, interviews, the 2015 international Acapulco mining conference, and previously mentioned literature, I analyze the weaknesses of Mexican institutions in their ability to mobilize Mexico's mining industry for economic development.

The section will begin by defining economic development and will provide a description of useful indicators that will be used to examine Canadian investment in Mexican mining. Following this, the theoretical framework of new institutional economics (NIE) will be used as a lens to analyse my quantitative and qualitative findings as they relate to Mexico's economic development. As explained in the theoretical review section, I will focus on how Mexican 
institutions effect economic development surrounding the mining industry in order to redirect emphasis away from Canadian influence and give agency to Mexican actors. NIE is an ideal theory to use in order to undergo an institutional analysis of economic development as it gives agency to both formal (e.g. laws, amendments) and informal (e.g. social norms, conventions) institutions that affect the mining industry. In order to provide context to the common discussion of the social impacts of mining, NIE will be used in order to unpack why some social issues arise, and how they could potentially be prevented.

\section{Economic Development in Mining: Three Areas of Focus}

Defining economic development is a contentious issue as there is much debate as to what it means, how it can be measured and which indicators are the most important. Some question whether mining for the purpose of economic development should be pursued at all, especially considering the cultural, environmental and social costs of capitalist expansion. ${ }^{139}$ Development theories such as neoliberalism, modernization, feminism, and theories of the developmental state foster distinct beliefs in regards to what economic development means and how to achieve it. For the purpose of this thesis, economic development is considered to be derived from a combination of economic growth and structural change. ${ }^{140}$ As such, positive economic development would involve positive GDP growth rates, combined with the evolution of new and efficient formal government institutions to guide the growing economy and its population. Despite criticisms that an overwhelming focus on GDP growth is not conducive to measuring development progress on its own, it remains a proxy for development. Institutional change is considered to be at the heart

\footnotetext{
${ }^{139}$ Eduardo Gudynas, “Ante esa obscura obsesión por el oro, es necesaria una moratoria minera" America Latina en Movimiento, http://www.alainet.org/es/active/73652.

${ }^{140}$ Nabli and Nugent "The New Institutional Economics and its Applicability to Development" World Development 17.9 (1989): 1342.
} 
of the economic development process, providing the link between growth and development. ${ }^{141}$ This is because without proper institutions the long-term effects of certain economic activities, such as mining, are not considered by investors who are oriented towards short-term gains. However, deciding which institutions should be created, and how to maintain them are also contentious issues. To reiterate, economic development is defined as an effort to improve economic well-being and quality of life by creating and/or retaining jobs, increasing incomes and augmenting the tax base for equitable distribution purposes. As explained in the literature review section, mining has received a lot of criticism regarding its effect on the environment. For this reason, having a positive impact on citizens' well-being is crucial for the justification of maintaining existing mining properties and developing new ones. NIE is a specifically useful tool to analyse whether economic development is occurring because it recognises the faults of neoliberal arguments in that markets are not perfect, and therefore must be guided by constructive institutions.

In order to analyse the extent to which Canadian mining companies have contributed to Mexico's economic development, I have used three indicators in order to gauge the potentials for mining to have a positive economic development impact: employment, value added products and services, and public revenue. These indicators were selected as a result of extensive research on development impact assessments regarding mining FDI in developing countries. ${ }^{142}$ Similar to other major industries, the mining sector has direct and indirect effects on countless areas of Mexican public and private life. For example, the development of a mine in a certain region

\footnotetext{
${ }^{141}$ Ibid, 1340.

${ }^{142}$ UNCTAD World Investment Report (2007), CEPAL La Inversión Extranjera en América Latina y el Caribe (2007), Ciaran O'Faircheallaigh, Mining and Development, (New York: St. Martin's Press: 1984), James Otto et. al Mining Royalties: A Global Study of Their Impact on Investors, Government and Civil Society (Washington DC: The World Bank, 2006).
} 
could decrease the need for remittances and discourage emigration. However, the same mine could also create tensions in a community if some individuals get jobs while others do not, or if competition for water supplies are amplified. In order to make this thesis manageable I decided that a focus on employment, value added, and public revenue would provide the most accurate and encompassing view of how Canadian mining affects Mexico's economic development.

Other important factors to consider when determining how mining FDI affects Mexico's economic development include: the effect of mining on other regional industries (such as agriculture), how mining exports affect Mexico's balance of payments, infrastructure development, knowledge transfers, environmental degradation and problems related to social cohesion. Each of these areas is an important economic determinant of mining, but I decided that they are less telling of the overall impact of the industry than the three previously mentioned indicators. Since mining makes up less than 3\% of Mexico's GDP, a variation in metal exports would be unlikely to affect Mexico's balance of payments, as it could in a country that is more resource dependant. Infrastructure development can be a very important outcome of mining; providing roads, electricity, sewage and other services in poor, rural areas that may not have received such services before. While these developments may help local communities in some cases, there is little opportunity to use the mine's infrastructure for other industries since most mining developments are in arid, northern states with little prospects for other economic activities such as tourism or manufacturing. Knowledge transfers, social cohesion and environmental degradation are also very important factors to consider in Mexico's mining industry, however they are outside the scope of this thesis. ${ }^{143}$ This section will provide some

\footnotetext{
${ }^{143}$ Some other studies that have documented the effect of these other indicators include: UNCTAD World Investment Report (2007), CEPAL La Inversión Extranjera en América Latina y el Caribe (2007), Ciaran O'Faircheallaigh, Mining and Development, (New York: St. Martins Press: 1984), Tamos Bos et. al, "Innovation,
} 
analysis of knowledge transfers, social cohesion and environmental degradation. However, I do not claim to provide an exhaustive understanding of these phenomena as they are very difficult to measure conclusively. The section emphasizes the interaction between Mexican institutions and Canadian firms, rather focusing exclusively on Canadian interests, in order to provide an understanding of how Canadian mining projects affect Mexico’s economic development.

\section{Employment}

Literature surrounding the economics of extractive industries suggests that metal mining creates very little employment, especially considering the substantial revenues made by firms. ${ }^{144}$ Canadian companies have a particularly privileged access to new technologies as a result of the clustering of the world's largest multinational mining firms within Canada. ${ }^{145}$ New technologies are constantly making mining more economically efficient and less labour intensive. Over the past twenty years Canadian firms have preferred to develop open-pit (rather than underground) mines, which are less prone to industrial accidents, but require a significantly smaller workforce. For example, 27 of the 46 Canadian owned mines in Mexico were open-pit in $2014 .{ }^{146}$ The new technologies and open-pit style mines utilized by Canadian firms have created very profitable advantages. For this reason, it is unreasonable to expect Mexican policymakers to create labour policies conducive to increased employment, since these technologies can no longer be ignored.

\footnotetext{
Entrepreneurship and Clusters in Latin America: Natural Resources - Implications and Future Challenges", Journal of Technology Management and Innovation 3.4 (2008): 52-63, Martin Arias et. al, "Large Mining Enterprises and Regional Development in Chile: Between the Enclave and the Cluster", Journal of Economic Geography 14 (2013): 73-95. institutions in a particular field. Canada is a major global mining hub, giving Canadian mining firms access to networking opportunities by organizations such as the Prospectors and Developers Association of Canada (PDAC), which allows for an increased access to new technologies.

14627 of the 46 Canadian owned mines in Mexico were open-pit in 2014.

Source: Appendix 1: Mining Production in Mexico, 1996-2014.
} 
Therefore, a stronger focus on the potential positive impacts of Mexican institutions will be employed below when discussing the other two indicators - value-added services and products and public revenue. It is important to note that the number of employees a mining firm hires is the most important factor regarding the employment indicator, but there are other aspects to consider. Other employment factors to recognise include: the rate of pay, what type of labour is hired locally (low-skilled, high-skilled, management, research and development (R\&D), consultants, gender, etc.), health and safety conditions, the geography of employment, and the possibility of knowledge transfers. This subsection will attempt to aggregate all of this information and provide a conclusion regarding the extent to which Canadian mining investment aids Mexico's economic development through employment.

Using data from the Secretary of the Economy, the CAMIMEX website states that in 2014 there were 340,817 jobs in the mining industry in Mexico. ${ }^{147}$ That number is likely accurate when considering all jobs in the broader mining industry, including non-metallic extraction (such as salt, graphite, cement, coal, fluorite, etc.), welding, and post-production (such as making pipes or sheet metal). However, the data used by CAMIMEX and other industry leaders was found to be unrepresentative of the real mining labour force when compared against other, more specific, Secretary of the Economy data. A document I received while visiting the Mining department of the Secretary of the Economy in Mexico City indicated that 2014 employment in extraction was 111,038 , while jobs in the metal mining sector amounted to only $68,377 .{ }^{148}$ These data indicate that in 2014 non-metallic mining made up less than $15 \%$ of total revenue in the mining sector,

147 "Boletín Informativo, Agosto 2015", CAMIMEX website, https://www.camimex.org.mx/index.php/boletines/?boletin=03\%20de\%20Agosto\%20de\%202015, accessed February 4, 2015.

${ }^{148}$ Document from the General Mining Coordination Office of the Secretary of the Economy: PRONTUARIO: Industria Minero Metalúrgica, Coordinación General de Minería, Secretaría de la Economía, Septiembre 2015, 32. 
but provided $38.5 \%$ of jobs. ${ }^{149}$ Therefore one can conclude that metallic mining, the industry that Canadian firms are exclusively concerned with, is much less labour intensive than non-metallic mining. Amalgamating employment data from non-metallic mining, metallic mining, and postproduction has allowed industry leaders to provide ambiguous information regarding the economic development effects of mining investment.

Data collected from annual company reports indicate that Canadian mining companies employed about 25,434 people in Mexico in 2014, or roughly 7.2\% of mining industry employees, according to the amalgamated figure $(340,817$ jobs $)$ provided by the Secretary of the Economy. ${ }^{150}$ In 2014 Canadian firms made a combined total of $\$ 6.3$ billion in revenue, which translates to about one job for every $\$ 250,000$ in revenue. ${ }^{151}$ Put differently, Canadian mining production made up $0.45 \%$ of Mexico's GDP in 2014 , yet provided employment to only $0.04 \%$ of the entire Mexican workforce. ${ }^{152}$ These data indicate that employment in the mining industry, and especially employment from Canadian mining firms, is minimal in comparison with the revenues earned by the companies, and the industry's overall share of Mexican GDP.

One can examine employment in the mining industry in Mexico's most important mining state, Zacatecas, in order to provide a more specific example of this phenomenon. The Director of Mines at the Secretary of the Economy of Zacatecas stated in an interview that there was

\footnotetext{
${ }^{149}$ Situación de la Minería en México en 2014, Informe Anual, Cámara Minera de México (CAMIMEX), 2015.

${ }^{150}$ Appendix 1: Mining Production in Mexico, 1996-2014.

${ }^{151}$ Appendix 1: Mining Production in Mexico, 1996-2014.

${ }^{152}$ Canadian mining production and employment derived from Appendix 1: Mining Production in Mexico, 19962014.

The total Mexican GDP was derived from the Global Affairs Canada website: http://international.gc.ca/globalmarkets-marches-mondiaux/markets-marches/mexico-mexique.aspx?lang=eng, accessed on January 13, 2016.

Employment by Canadian companies figure extracted from data research. The total Mexican labour force $(55,561,477)$ was extracted from the World Bank website: http://data.worldbank.org/indicator/SL.TLF.TOTL.IN, accessed on January 13, 2016.
} 
"much direct employment" from mining in the state - 11,700 jobs in $2014 .{ }^{153}$ However, with 605,658 economically active adults in Zacatecas, the mining sector directly employed less than $2 \%$ of the formal labour force in $2010 .{ }^{154}$ Interviews with financial directors of some Canadian firms also demonstrated a belief that Canadian participation in the mining industry created significant employment. These interviews created an interesting perspective because they demonstrated how mining is perceived to be a job creator, even by industry experts, when in reality it generates very little employment compared to the revenues being earned.

To provide another example, the largest mine owned by a Canadian company in Mexico, Goldcorp's Peñasquito mine, employed 3,200 people (including contractors) in 2014. ${ }^{155}$

Considering that the mine earned over $\$ 1.9$ billion in revenue in the same year, about one job was available for every $\$ 595,000$ in revenue. ${ }^{156}$ A director at Goldcorp's Mexico office stated in an interview that the company is required to maintain job quotas for community members in the region as a result of a land lease agreement and requirements set by the mine's union. The director informed me that in practice this means some employees are paid to do unnecessary tasks in order for the company to be able to maintain employment levels. ${ }^{157}$ This finding demonstrates that the workforce at Goldcorp's Peñasquito mine is already bloated, even though the number of Mexican employees working at the mine are relatively few. This example also

\footnotetext{
${ }^{153}$ Magdallenes, Juan de Dios. Interview by Sean Cornelissen. Unrecorded. Zacatecas, October 14, 2015. Confirmed by data in Prontuario document (2015). It is likely that this figure includes non-metallic mining, as well as employment in post-production industries.

${ }^{154}$ Figure calculated dividing total number of Zacatecas citizens over age 14 by the economically active percentage of that population (47.8\%). It should be considered that the majority of the remaining $52.2 \%$ of non-economically active citizens likely work in informal sectors of the economy, which would make the overall percentage of employment in mining in Zacatecas even less. Source: "Panorama Sociodemográfico de Zacatecas" INEGI, (2011). 155 "Peñasquito - Overview \& Operating Highlights", Goldcorp Website, http://www.goldcorp.com/English/Unrivalled-Assets/Mines-and-Projects/LatinAmerica/Operations/Penasquito/Overview-and-Operating-Highlights/default.aspx, accessed February 4, 2016. 156 Appendix 1: Mining Production in Mexico, 1996-2014.

${ }^{157}$ Harvey, Michael. Interview by Sean Cornelissen. Mexico City, November 24, 2015.
} 
indicates how industry leaders stress the importance of job creation in the mining industry, even though jobs are few when compared to revenues earned by companies, and are sometimes created to maintain job creation promises, rather than out of necessity.

Interviews suggested that it is common practice for Canadian mining companies to hire exclusively Mexican employees. There was a consensus among all of the financial and corporate directors interviewed (some being Mexican themselves) that all of their firms' in-country employees (both labourers and office workers) are Mexican nationals, which is part of their commitment to contribute to Mexico's development. The interviewees also suggested that Canadian firms prefer to hire individuals from nearby communities, whenever possible. All private and public sector officials that were interviewed maintained that local employment provides the mining sector with legitimacy and allows local populations to take ownership in the operations. To be clear, all of the individuals representing Canadian mining firms that I interviewed were Mexican citizens, with the exception of one individual.

The financial director of a Canadian copper mine in Zacatecas stated that over $90 \%$ of all the mine's employees are from the state of Zacatecas, and that the remaining $10 \%$ of workers are Mexicans from other states. ${ }^{158}$ In the case of this property, the land which hosts the mine was purchased (rather than rented, which is the norm) from the local ejido population, freeing the company of contractual obligations to local employment. However the company has learned to employ locals from the nearby ejido, even though they are not contractually required to do so, in order to avoid local conflicts which lead to a loss in profits. Interviews suggested that hiring a purely local work force is a 'win-win' for Canadian companies operating in Mexico. It can be

${ }^{158}$ Zapata, Jesus Espino. Interview by Sean Cornelissen. Zacatecas, October 13, 2015. 
recognised that employment not only creates legitimacy and reduces the possibility of local conflict, but it also provides the company with cheaper labour than the wages foreign workers would expect to earn. As a result, the majority of jobs created in Mexico by Canadian mining companies are filled by a local, Mexican work force.

Private and public sector representatives stated in interviews that Canadian managers were often unable to predict or respond well to notorious cases of social conflict and demonstrations throughout the 2000s. ${ }^{159}$ The Director of International Investment for mining at the Secretary of the Economy stated in an interview that Canadian junior companies were notorious for arriving at a new mining concession and beginning exploration operations without first introducing themselves to local populations. ${ }^{160}$ According to the Director, a lack of cultural understanding created preventable tensions between Canadian companies and community members in a number of cases. Interviews suggested that, as a result, most Canadian companies have moved to hire locals for management positions in Mexico, rather than Canadians. Indeed, all financial directors of Canadian mines interviewed for this research project were Mexican. Based on my observations, Canadian mining companies' have significantly altered their employment strategy to include local management positions throughout the past decade in order to keep local populations content, gain legitimacy, and maintain production.

Interviewees demonstrated a unanimous belief among Canadian government officials, Canadian firms, and all three levels of Mexican government that mining's most important

\footnotetext{
${ }^{159}$ In two interviews with officials from the Secretary of the Economy, the negligent actions of Blackfire Exploration were brought up. As explained below, Blackfire Exploration has become infamous for its alleged complicity in the murder of activist Mariano Abarca.

${ }^{160}$ Lizardi, Jorge Fernández and Mejía, Noé Reyes. Interview by Sean Cornelissen. Unrecorded. Mexico City, November 14, 2015.
} 
contribution to economic development is employment. ${ }^{161}$ Interviewees stated that mining jobs paid better than remunerated activities requiring a similar skill set; and that the jobs were located in rural areas with little access to formal employment. Both of these suppositions are largely correct. In Mexico, the minimum wage ${ }^{162}$ in 2014 was $\$ 65.58$ MX pesos per day ${ }^{163}$, yet the average employee in the metal mining industry made $\$ 494.40 \mathrm{MX}$ pesos per day. ${ }^{164}$ If one were to inquire about average salaries in the rural areas of Mexico's poorest northern states (where most Canadian mines are located) the contrast of the remuneration earned by miners would likely be even more dramatic. Conference speeches, available data and interviews indicated that Canadian mining companies are especially concerned with the health and safety of their workers because any injury has the potential to suspend operations and negatively affect the company's stock prices. ${ }^{165}$ Interviews suggested that in poor rural areas with a mining history new mine developments are often welcomed by local governments and some local populations because of the high pay, decent working conditions and a lack of other employment options.

For example, the Director of Economic Development of the tiny Municipality of Morelos, Zacatecas clarified that before the arrival of a Canadian copper mine, the only local industry was small-scale agriculture, which was usually subsistence based. ${ }^{166}$ The company

\footnotetext{
${ }^{161}$ One of the questions which I utilized in nearly every interview was, "How does the mining industry affect Mexico's economic development?" to which respondents always contested, "creating jobs".

${ }^{162}$ It is important to remember that this minimum wage refers to formal employment, while jobs in the informal sector can be much lower. A document produced by the International Labour Organization, for example, estimated that as many as $60 \%$ of Mexicans are in the informal sector: http://www.ilo.org/wcmsp5/groups/public/---americas/--ro-lima/documents/publication/wcms_245889.pdf

163 “Ocupación y Empleo: Remuneraciones", INEGI website, accessed January 19, 2016, http://www3.inegi.org.mx/sistemas/sisept/default.aspx?t=eemp20\&s=est\&c=25700

164 "Salario Promedio de Cotización por Sector y Rama de Actividad 2010-2015", document provided by the General Mining Coordination Office of the Secretary of the Economy: PRONTUARIO: Industria Minero Metalúrgica, Coordinación General de Minería, Secretaría de la Economía, Septiembre 2015, 35.

${ }^{165}$ Anonymous interview.

${ }^{166}$ Reyes, Gilberto and Fajardo, Isaac. Interview by Sean Cornelissen. Unrecorded. Morelos, Zacatecas November $14,2015$.
} 
signed an agreement with the municipality to create employment for the citizens of Morelos, which solidified mining as a welcomed industry in the municipality. ${ }^{167} \mathrm{An}$ interview with municipal directors of Morelos demonstrated that mining is very important for the local economy of Morelos, which has few other sources of formal employment. This information suggests that although employment provided by Canadian mining companies is trivial in Mexico on a national scale, the local jobs that are created can be very important to certain municipalities.

Another important factor to consider is that the majority of jobs that are created through mining are non-transferable in the job market as a result of the specialized type of labour used in mining. ${ }^{168}$ While other industries such as manufacturing, research and development $(R \& D)$, and technology-intensive productions have the potential to teach labourers transferable skills, the mining industry creates few knowledge spill-overs. The reason for this phenomenon is that the majority of jobs that are created for the local Mexican labour force are low-skilled labour positions, which require little training applicable to other industries. This is important to consider when prices drop and mines lay off workers, or when a mine has depleted its resources and shuts down indefinitely. In such a situation, the lack of education and skilled human resources in the mining sector in general can limit the potential positive effects of the applicability of knowledge transfers to other sectors of the economy. ${ }^{169}$

Despite efforts by Canadian mining firms to hire Mexican employees for all in-country positions, from 'broom pushers' to managing directors, employment via Canadian mining on a national scale has been trivial. Although few jobs are generated, a focus on maintaining

\footnotetext{
${ }^{167}$ Ibid.

${ }^{168}$ Ciaran O'Faircheallaigh, Mining and Development, (New York: St. Martins Press: 1984): 277, UNCTAD World Investment Report (2007), CEPAL La Inversión Extranjera en América Latina y el Caribe (2007),

${ }^{169}$ UNCTAD World Investment Report (2007): xxiv.
} 
production has kept companies responsible in terms of worker safety, fair payment for labour, and hiring local populations. The findings of my research suggest that although jobs in the mining industry are high paying, the industry's overall effect on national employment is negligible. Therefore, the amount of economic development that occurs as a result of Canadian investment in a new or existing property is also limited when considering Mexico's development holistically. The effect of employment in mining on Mexico's economic development is also hindered by an inability to transfer the skills and knowledge gained in the industry to new enterprises. This phenomenon makes economic growth and innovation less likely to grow from the mining industry, an issue which will be discussed further below. It is clear that mining companies have made significant efforts to provide job opportunities to professional and working class Mexicans. However, the effects that new mining technology and open-pit style mines have on labour restricts the ability of Canadian mining firms to have a significant impact on Mexico's economic development. There is little that can be done by institutions to remedy the issues surrounding low employment at an aggregate level because new technologies and open-pit mining are external factors which cannot realistically be controlled by the Mexican government. Mining activity may be deemed worthwhile for certain municipalities that lack other industries, but this thesis is primarily concerned with examining mining at a national level. Therefore, an institutional analysis of how Canadian mining affects economic development in Mexico is more salient when examining the two indicators outlined below: value-added products and public revenue.

\section{Value Added Products and Services}

The significance of value-added products and services in the context of economic development refers to the facility of creating business and employment in other sectors that are 
indirectly related to the mining industry. In order to more accurately approach the subject, I have broken up value added possibilities into two categories - backward linkages and forward linkages. ${ }^{170}$ A hypothetical example of a backward linkage is the creation of a heavy equipment factory in Mexico from which mining companies could purchase machines. The factory would provide employment and public revenue in its daily operations, it would require a variety of inputs which could create more growth and business opportunities, and it would provide domestically built machines which could eventually be exported or used in other domestic industries. A theoretical example of a forward linkage in the mining industry is the introduction of copper wire production to the Mexican economy. Manufacturing copper wire, rather than exporting copper by the tonne, would create employment, generate government revenue and open avenues for Mexican companies to begin producing electronics and other products. The potentials that value added products and services have for economic development are great, however they must be sought after by Mexican entrepreneurs, and supported by the government.

The financial director of a Canadian silver company stated in an interview that indirect employment created through [backward] linkages in the local economy must be factored into the company's impact on economic development. ${ }^{171}$ The individual clarified that the development of a mine creates employment in other parts of the economy, like cleaning and food preparation. These services could be seen as backward linkages to the Mexican economy, as the mining companies are purchasing products (cleaning services and prepared food) in-country, rather than importing them. However, these types of positions are low-skilled, not well paid, and most importantly, businesses providing these services are unlikely to continue making linkages with

\footnotetext{
${ }^{170}$ Backward linkages refer to the flow of money, knowledge and other goods between a business and its suppliers. Forward linkages refer to the distribution chain between a business and the consumer.

${ }^{171}$ Anonymous interview.
} 
other industries. If low-skilled businesses that serve the mining industry do not expand then the jobs that were created in association with the mine will no longer exist when the mine is closed. To have a business in a value chain serve industries outside of the original industry it was created for is crucial to enabling economic growth and creating competition among employers. Cleaning, food preparation services, transportation, and other low-skilled tasks neither require nor spark the innovation necessary for an industry to expand into new areas and become an effective backward linkage to other parts of the economy. In Mexico, it seems that low-skilled services are the main type of 'backward linkages' associated with mining.

Analysing company reports clarified that the majority of metals produced in Mexico by Canadian companies are exported directly, meaning that forward linkages in the sector largely do not exist. Most Canadian companies (42 of 46) are primarily involved in the extraction of silver and gold. ${ }^{172}$ Typically, precious metals like gold and silver are exported directly because of their high value in crude form and their limited industrial uses. The remaining four Canadian mines in Mexico primarily produce copper. ${ }^{173}$ The financial director of one Canadian copper mine said in an interview that the firm's production centre exports copper directly to China, and does not sell the metal domestically, or make any in-country products with it. ${ }^{174}$ Although copper has many more possibilities for creating value-added products than gold or silver, Canada's largest copper producer in Mexico has not sought these opportunities. Considering that the other three Canadian owned mines producing copper are smaller in scale, it is unlikely that any Canadian copper mine makes value-added products. The chief accountant of a Canadian silver mining company explained that currently the high-valued US dollar makes it convenient for companies to export

\footnotetext{
172 Appendix 1: Mining Production in Mexico, 1996-2014.

173 Appendix 1: Mining Production in Mexico, 1996-2014.

${ }^{174}$ Zapata, Jesus Espino. Interview by Sean Cornelissen. Unrecorded. Zacatecas, October 13, 2015.
} 
metals 'as such' for US dollars. Indeed, data from the Secretary of the Economy indicate that the majority of mining production is exported to the US, regardless of the mining company's country of origin. ${ }^{175}$ The few possibilities that precious metals provide for value-added potentials and the convenience of the high US dollar are major contributing factors to why Canadian companies create few, if any, forward linkages in the Mexican economy.

Furthermore, Canadian firms have failed to make effective backward linkages with the Mexican economy when purchasing inputs for their mines. Forward linkages created by Canadian firms are also unlikely to develop, largely because of the limited possibilities that precious metal extraction provides for creating value-added products. A study which compared FDI in metal mining in four different countries found that backward linkages were unlikely to occur, except in cases where industries were established to serve the mining sector before the industry was developed. ${ }^{176}$ In other words, mining was not found to create new industry through backward linkages. Similarly, forward linkages were also found to be improbable as foreign investors were reluctant to undertake post-production activities in host countries. ${ }^{177}$ The study revealed similar findings to my research in that mining and mine infrastructure did not facilitate the emergence of new industries in host countries. Interestingly, the researcher also found that "a failure to optimise benefits was almost entirely due to... institutional factors which militated against effective policy making, and which were generally unrelated to the host country-foreign investor relationship." 178

\footnotetext{
175 "Exportaciones Minero Metalúrgicas por País 2010-2015", document provided by the General Mining Coordination Office of the Secretary of the Economy: PRONTUARIO: Industria Minero Metalúrgica, Coordinación General de Minería, Secretaría de la Economía, Septiembre 2015, 39.

${ }^{176}$ O'Faircheallaigh, Mining and Development: 275.

177 Ibid: 278 .

${ }^{178}$ Ibid: 289.
} 
Since the mining industry does not naturally generate forward and backward linkages, it may seem logical to use formal institutions to encourage the creation of value added products in Mexico's mining economy. If looking for an exemplar and recent model, the Chilean government undertook a significant effort to create a mining cluster in the Antofagasta region. ${ }^{179}$ Although copper is Chile's primary export and made up over 14\% of its GDP during the commodity boom (2003-2012), very few value-added industries have been generated from Chile's mining industry. ${ }^{180}$ The Chilean government has been attempting to create a mining cluster in the Antofagasta region since 2005 in order to reverse this trend, encourage innovation in the industry, and create links to other parts of the economy. ${ }^{181} \mathrm{~A}$ study has shown that despite years of government intervention and many programs supporting the initiative, a cluster has not been created in the Antofagasta region. ${ }^{182}$ The regional economy continues to export almost all metals directly and $89 \%$ of suppliers are either foreign, or based in Santiago. ${ }^{183}$ Based on the Chilean government's attempt to create a mining cluster, it seems that a successful institutionalized effort to encourage the creation of value added products would require unprecedented levels of government intervention.

The chief lesson to be learned from this case is that there exist few incentives for foreign investors to engage with, and transfer knowledge to, local suppliers. Policymakers must first recognise that by and large, the existence of knowledge transfers between MNCs and local

\footnotetext{
${ }^{179}$ Tamos Bos et. al, "Innovation, Entrepreneurship and Clusters in Latin America: Natural Resources - Implications and Future Challenges", Journal of Technology Management and Innovation 3.4 (2008): 54 52-63.

${ }^{180}$ Martin Arias et. al, "Large Mining Enterprises and Regional Development in Chile: Between the Enclave and the Cluster", Journal of Economic Geography 14 (2013): 92. 73-95

181 "Mining Cluster in Chile", InvestChile Corfo, Chilean Economic Development Agency (2007).

182 Martin Arias et. al: 74.

${ }^{183}$ Martin Arias et. al: 87.
} 
workers in the mining sector is a myth. ${ }^{184}$ Doing so could put the Mexican government in a position to take advantage of the stationary nature of its natural resources, and implement policies that encourage knowledge and skill transfers in the production chains related to mining. Arias et. al. cite the example of the Bothnian mining site on the border between Finland and Sweden as an ideal mining cluster that has fostered innovation, created meaningful links to the local economy, and exports a very small portion of production in a raw form. ${ }^{185}$ If Mexican policymakers wished MNCs to have a similar effect, they could learn from the failures and successes experienced by both the Bothnian and Antofagasta mining regions.

In an interview with the Director of International Investment in mining at the Secretary of the Economy, I was informed that the Peña Nieto administration had developed a mining action plan with a specific focus on value-added products. ${ }^{186}$ The director and his associate informed me that the document outlining the initiative dictated how the new government intended to create clusters in mining regions. ${ }^{187}$ Two of the main goals outlined in the document include improving value chains and institutional efficiency - two efforts that this research has led me to believe are crucial in creating a well-designed mining industry. However, specific aspects of how the Peña Nieto administration intends to measure success in the creation of a mining cluster are troubling. For example, 'value chain creation' is measured by how much capital is lent to foreign and domestic firms by the Trust Fund for Promotion of Mining in Mexico (FIFOMI) ${ }^{188}$, rather than

\footnotetext{
${ }^{184}$ Martin Arias et. al, "Large Mining Enterprises and Regional Development in Chile: Between the Enclave and the Cluster": 92.

185 Ibid: 75 .

186 The Mining Development Program Agreement 2013-2018, in Spanish, Acuerdo Programa de Desarrollo Minero 2013-2018, Diario Oficial, http://www.dof.gob.mx/nota_detalle.php?codigo=5344070\&fecha=09/05/2014, accessed January 12, 2016.

${ }^{187}$ Lizardi, Jorge Fernández and Mejía, Noé Reyes. Interview by Sean Cornelissen. Unrecorded. Mexico City, November 14, 2015.

${ }^{188}$ FIFOMI is under the umbrella of the mining department of the Secretary of the Economy and primarily exists to provide loans to "small and medium" mining companies to explore and develop mining sites, as well as make
} 
the number of new businesses or jobs that are created, and are sustainable in the long term. Similarly, 'institutional efficiency' is measured by how much wait times are decreased on concession entitlements for firms, rather than a reduction in land disputes or environmental problems. $^{189}$

Despite the current government's recognition of the need to improve value chains and institutional efficiency, the way in which the project is monitored demonstrates a serious lack of commitment. Peña Nieto’s mining development plan, and the unfamiliarity of forward and backward linkage potentials demonstrated in interviews by Mexico's top mining officials, manifests major weaknesses in Mexico's federal institutions. In other words, these findings indicate either an unawareness of the importance of using formal institutions to foment economic development, or an unwillingness to do so. Although Canadian mining firms would have less of an effect on product value chains than Mexican firms (because of their focus on precious metals rather than industrial metals), a mining development plan that recognises the importance of creating value added products and services linked to the mining industry could encourage Canadian firms to support backward linkages in the economy. Natural resources such as subterranean metals are immobile, which gives a host country like Mexico considerable leeway to make favourable policies with minimal possibilities of capital flight. This means that once a foreign firm has invested in the development of a mine, profits are reliant upon the company maintaining high production levels. The Mexican government should take advantage of this phenomena and use policy to create an economic environment which encourages innovation and

\footnotetext{
linkages with local economies. An interview with a Director from the Ministry of Finance and Public Credit revealed that in practice, FIFOMI serves to provide mostly large and existing companies with cheap capital to finance new projects. Nowhere in the Mining Development Program Agreement is any incentive or encouragement given to FIFOMI to actively pursue forward linkages in the mining industry.

189 Acuerdo Programa de Desarrollo Minero 2013-2018, Diario Oficial.
} 
entrepreneurship in the mining sector, given their acknowledged importance as economic development contributors.

Economies of scale suggest that the large size of Mexico's economy should be beneficial to creating value-added products related to mining. Mexico is chiefly a manufacturing economy with relatively cheap labour and access to a variety of imports, making it an ideal candidate for supplying companies with machinery, as well as making post-production goods. Nevertheless, almost all new machinery is imported and nearly all metals produced are exported directly, which was clearly stated in three interviews with financial directors of Canadian companies. Finning International (a Canadian company) is a favoured supplier of Caterpillar machines, parts, and even mechanical training, as shown in most companies' annual expense reports. At the XXXI International Mining Convention in Acapulco, Mexican companies had a very small presence in the suppliers section, which was dominated by Canadian, US, and European companies. A key note speaker at the conference, economist Luis de la Calle (President of Hill and Knowlton Latin America Division), encouraged an audience of thousands of Mexican industry leaders to be innovative in their creation of new products using the metals they extract. Better incentives and more enthusiastic encouragement from the Mexican state could inspire companies to take advantage of Mexico's large economy and its strengths in manufacturing. Inspiring forward and backward linkages with the mining sector could help the Mexican economy diversify and grow, increase public revenue, and provide employment opportunities. Some policy suggestions of how to accomplish this goal will be provided in the conclusion.

A Canadian firm's financial director, and a representative of the Canadian government, stated in interviews that mining is seen by the public as an old industry which does not represent 
development or import cutting-edge technologies. They both argued that the sector's association with antiquity is why it receives more negative attention than other industries. Indeed, mining technology innovation and the knowledge economy that is associated with mining happens primarily outside of Mexico. A significant hindrance to the development of Mexico's mining economy is that most mining companies develop R\&D domestically, and only use foreign properties to test new technologies. ${ }^{190}$ The same is true with the major consultancy and procurement agencies that serve mining interests in Mexico. These agencies (Price Waterhouse Coopers (PwC), Deloitte, KPMG, SNC-Lavalin, etc. $)^{191}$ are based in Canada and other developed countries and most of their representatives, even in Mexican offices, are foreigners. ${ }^{192}$ Meanwhile, quotes from industry leaders in the 2015 Mexican Mining Review demonstrate that the Mexican education system is not producing enough engineers and technology professionals to fill the gap of human talent that is currently retiring. ${ }^{193}$ Therefore it is not clear if high-skilled employment related to the mining industry is dominated by foreign employees because of preference, or out of necessity.

Canadian firms establish linkages with high-value industries such as R\&D and consultancy outside of Mexico, while taking advantage of the country's mineral riches and lowskilled labour. Encouraging in-country linkages with innovative industries could provide highvalued employment domestically, and would create jobs with knowledge transfer possibilities. As discussed in the employment section, knowledge transfers are important in value-added

\footnotetext{
${ }^{190}$ Martin Arias et. al: 90.

${ }^{191}$ Capítulo IV: "La inversión extranjera directa de Canadá en América Latina y el Caribe", Comisión Económica para América Latina y el Caribe de la Naciones Unidas (UNCEPAL): 198.

${ }^{192}$ All individuals I met at the Acapulco mining conference and at other networking events from consulting firms were from Canada, Australia, and Scandinavian countries.

193 “Main Trends Facing the Mexican Mining Industry in 2015”, Mexico Mining Review 2015.
} 
processes as they allow actors in one organization to benefit from the experiences of another. Currently, this does not occur very often in the Mexican mining industry. Canadian mining firms would benefit from employing Mexicans in skilled positions as their principal operations may be considered less archaic by the public and may reduce societal opposition to the industry. It is crucial to explore all potential avenues of value added processes in Mexico's mining economy in order to accelerate economic development. ${ }^{194}$

A lack of innovation and the importation of technology are not issues that are experienced exclusively by Mexico's mining industry. ${ }^{195}$ In fact, the case has been made that Mexicans are terrific entrepreneurs, but lack a culture of innovation. ${ }^{196} \mathrm{New}$ institutional economist Acemoglu points out that in Mexico a monopolized economy, forced labour, and a workforce dependent upon elites persisted long after independence, until the revolution in 1910. ${ }^{197}$ This situation created informal institutions within Mexican society which do not encourage innovation, and instead encourage the working class to earn wages (rather than profits) from the elites. ${ }^{198}$ While the author focuses his analysis on the necessity of property rights, I contend that a lack of formal state institutions to encourage innovation in Mexico's mining sector has also been a very significant factor. A study concerned with determining why innovation is lacking in contemporary Latin America highlighted the following institutional weaknesses: insufficient policies regarding innovation and technology, limited interaction between government, universities and industry, high emigration of most valued researchers,

\footnotetext{
194 UNCTAD, 141.

195 Tamos Bos et. al, "Innovation, Entrepreneurship and Clusters in Latin America: Natural Resources - Implications and Future Challenges", Journal of Technology Management and Innovation 3.4 (2008): 53 52-63.

196 Ibid.

${ }^{197}$ Daron Acemoglu et. al, "The Colonial Origins of Development: An Empirical Investigation”, The American Economic Review 91.5 (2001): 1376 1369-1401.

${ }^{198}$ Ibid, 1377.
} 
weak patenting laws, and low R\&D investment. ${ }^{199}$ The weakness of formal institutions has perpetuated the societal norm of adapting technologies from the developed world. This strategy generates smaller profits, and does not encourage the creation of new knowledge. North contends that changing informal institutions (or, societal norms) is a process which often takes hundreds of years. This conclusion is supported by the lack of innovation surrounding the Mexican mining industry.

The fact that the majority of Canadian mining firms in Mexico with the potential to create linkages in the economy are junior companies provides little hope that the private sector will be able to take on such an initiative on its own. Typically, junior companies are publicly listed firms driven by shareholders' expectations of the discovery of large mineral deposits - not creating other business linkages in Mexico. Furthermore, since prices fell in 2012, markets are less willing to support exploratory junior companies. ${ }^{200}$ If Canadian juniors were unlikely to invest in businesses that would add value to Mexican mining when metals prices were high, it is even less likely that they would take the initiative to do so in the current situation of low metals prices, and dramatically increased tax rates. Although Canadian participation in Mexico's mining sector has the potential to create value-added linkages within the Mexican economy, it is unrealistic to expect Canadian firms to take on such an initiative on their own. Rather than waiting for Mexico's societal norms of being employees rather than innovators to change, Mexico's government should bridge the gap and make policies with a focus on innovation and creating value chains. Based on the goals outlined in the current government's mining action plan, it is clear that the government is aware of the need to create institutions and encourage industrial

\footnotetext{
199 Ibid: 54.

200 "World Exploration Trends 2015", SNL Metals and Mining, prepared for PDAC International Mining Convention, 2015.
} 
linkages in the mining sector. However, formal institutions such as patenting laws ${ }^{201}$, innovation grants and public security must be improved in order to work towards creating backward and forward linkages. Such institutional initiatives could likely lead to a greater Canadian participation in Mexico's economic development in the mining sector.

\section{Government Revenue}

The third area that this thesis analyzes in order to determine the effects of Canadian mining on Mexican economic development is government revenue. Pubic income is potentially the most important factor affecting Mexico's economic growth and development that is derived from Canadian investment in the country's mining industry. As discussed above, the potential contribution of Canadian mining firms to employment in Mexico is limited as a result of the technology that has been adapted, and the open-pit mining style that is often used. Significant linkages to Mexico's economy are hindered by Canadian firms' focus on the extraction of precious metals, which provide less value added opportunities than industrial metals. The data analysed for this project, as well as existing literature, ${ }^{202}$ suggest that precious metal mining is a capital-intensive industry (both in investment and revenues) with limited indirect economic benefits. As a result, collecting government revenue from the mining sector is likely the most

\footnotetext{
201 Tamos Bos et. al (2008) argue that weak patent laws in Mexico disincentivize entrepreneurs and innovators from staying in Mexico to develop new products, and these individuals instead often opt to move their business to the United States where patents are easier to solidify. Furthermore, the authors argue that it takes many more days, on average, to open a new business in Mexico than it does in other countries (both developed and developing) which also gives Mexican entrepreneurs to leave the country. Nevertheless, other studies have shown that increasing access to patents does not provide an overall more innovative economy.

202 The 2007 UNCTAD document "Transnational Corporation, Extractive Industries and Development" explicitly and repeatedly states that government revenue is the most important development implication of mining for all developing countries.
} 
significant way in which Canadian mining investments could aid Mexican economic development in the short to medium term.

As discussed in the Theoretical Review section, 'new left' governments in Latin America with significant natural resources began to implement 'neo-extractivist' policies in the 2000s in order to increase mining production rents. Prior to January 2014, Mexico was the only country in Latin America with a significant mining industry (by global standards) and the complete absence of a mining specific tax. Although the Mexican government has since imposed a $7.5 \%$ royalty (among other provisions) on all mining production, the country imposed the tax much too late, after metals prices and investment had already begun to fall. ${ }^{203}$ If Mexico had followed the lead of its regional peers and imposed its $7.5 \%$ royalty in the mid-2000s, I estimate that it would have recovered over $\$ 1$ billion per year in additional public income in metal mining alone. ${ }^{204}$ It is unlikely that implementing this policy earlier would have deterred much investment considering that countries with royalties in place, such as Peru and Chile, also received significant investment during the same period. Therefore, by not imposing the mining royalty earlier while metals prices were very high and companies had higher revenues, Mexico missed out on a great opportunity to increase its public revenues.

Elected officials in Mexico's congress were aware of how little public income was being earned in the mining sector since at least 2010. Reports submitted to Congress from the Auditor General's office (ASF) ${ }^{205}$ in 2010 and 2012 strongly recommended that royalties be implemented

\footnotetext{
${ }^{203}$ Puyana and Moreno (2016, forthcoming).

${ }^{204}$ This figure represents $7.5 \%$ of an accurate estimation of total metal mining production value from 2005-2013. As much data could not be found pre-2009, as discussed in the methodology section, it is likely that rents collected during this period would have been much higher than $\$ 7$ billion.

${ }^{205}$ In Spanish, Auditoria Superior de la Federación (ASF)
} 
in order to gain public income, and offset the public administration ${ }^{206}$ costs of mining. ${ }^{207} \mathrm{I}$ received a written response from the ASF which stated, "the problem [mining concession payments being lower than government administration fees] was known by everyone for a long time, however, for various reasons, action was not taken". ${ }^{208}$ It went on to explain that the low payment system was the result of a policy decision aimed at encouraging investment in the mining sector which lasted for more years than it should have. The ASF stated that it had made "diverse proposals for revisions" in order to change the administration of mining concessions. ${ }^{209}$ The response I received from the ASF demonstrated that their office, the Chamber of Deputies, and the Secretary of the Economy were aware of the problem of low mining rents for many years before taking action. Such a situation thus raises the question of why it took the Mexican government so long to impose a mining tax.

My original hypothesis was that Mexico's previous neoliberal federal government (National Action Party, or PAN) ${ }^{210}$ mandated low taxes in an attempt to attract investment throughout the commodity boom. I suspected that the implementation of royalties in 2014 were an attempt by Peña Nieto and the governing PRI to re-establish corporatist links in poor, rural Mexico and gain political capital in mining regions. However, two interviews provided considerable insight into other reasons explaining why mining royalties came so late in Mexico.

\footnotetext{
${ }^{206}$ Public administration costs of mining include paying personal to grant and file concessions, maintain the different sectors within the Department of Mines, and maintain safety and environmental protocols.

207 “Derechos sobre Minería", Informe del Resultado de la Fiscalización Superior de la Cuenta Pública 2010, Auditoría Financiera y de Cumplimiento.

"Otorgamiento de Concesiones e Ingresos por Derechos en Materia Minera", Informe del Resultado de la Fiscalización Superior de la Cuenta Pública 2012, Auditoría Financiera y de Cumplimiento.

${ }^{208}$ Written response from ASF office, October 2015: 2.

209 Written response from ASF office, October 2015: 4.

${ }^{210}$ In Spanish, Partido Acción Nacional (PAN)
} 
In the first interview, two government officials ${ }^{211}$ from the Mining Department of the Secretary of the Economy indicated that they had been involved in discussions regarding mining royalties since 2003, more than a decade before their implementation. These individuals recognised that the tax took a long time to implement, and indicated that the delicate nature of tax implementation was the primary reason why the taxes were not applied earlier. ${ }^{212}$ Another interview was conducted with a former director at the Secretary of Finance and Public Credit (SHCP). ${ }^{213}$ The individual was specifically hired to spearhead the mining royalty implementation project in 2010 - two years before Peña Nieto won the election, when the PAN government was still in power. All three of the above mentioned individuals clearly indicated that past PAN administrations were responsible for kick-starting the mining tax, negating my original hypothesis.

The SHCP director indicated that there was a feeling among public officials that the introduction of a mining tax would create limited government revenue, especially when compared to rents earned from Mexican oil. ${ }^{214}$ The director also stated that the political capital of Mexico's three largest mining companies, owned by Mexico's three wealthiest businessmen, played a significant role in the SHCP decision making process. Upon being hired, the director was warned by his hiring committee to be firm with his coworkers at the SHCP, because the majority were graduates of the Mexican Autonomous Institute of Technology (ITAM) ${ }^{215}$ This is significant because the ITAM is an exclusive, private university in Mexico that was founded in

\footnotetext{
${ }^{211}$ Lizardi, Jorge Fernández and Mejía, Noé Reyes. Interview by Sean Cornelissen. Unrecorded. Mexico City, November 14, 2015.

${ }^{212}$ By "delicate nature of new tax implementation" I suspect that the officials meant that new taxes are never popular amongst private sector interests, especially when considering the power of the Mexican private actors in mining.

${ }^{213}$ In Spanish, Secretaría de Hacienda y Crédito Público (SHCP).

${ }^{214}$ Farfan, Gabriel. Interview by Sean Cornelissen. Unrecorded. Mexico City, November 16, 2015.

215 In Spanish, Instituto Tecnológico Autónomo de México (ITAM).
} 
1946 by the father of Alberto Bailleres - Mexico's third richest man and owner of Mexico's largest mining firm, Industrias Peñoles. The former SHCP director informed me that the Mexican Chamber of Mines (CAMIMEX), the Canadian Mining Task Force (CMTF), and many large foreign and domestic mining companies attempted to dissuade him while he was writing the new tax laws. ${ }^{216}$ Since the majority of his coworkers at the SHCP were loyal to their linkages at the ITAM, the only support the individual received in drafting the legislation was from World Bank representatives. ${ }^{217}$ It is important to mention that the director was hired specifically for the task of writing the new mining law, and left the department immediately after doing so. This suggests that long-term employees in the SHCP were incapable of completing the task because of pressures from Mexico's business elites. The expectation that public servants at the SHCP would attempt to limit the taxation of Mexico's wealthiest people exemplifies a substantial weakness in the crucial government organization. The awareness of the interviewee's hiring committee of the collusion that exists in the department highlights a major institutional weakness in the organization that has executive authority of taxation laws.

Although Mexico's neoliberal PAN government likely played an important role in avoiding a mining tax, it seems there is an additional reason why Mexican policymakers were reluctant to implement mining tax reforms. Interviews suggested that the relatively small amount of tax income that was to be gained through a mining tax (upwards of $\$ 1$ billion per annum) was determined to not be worth angering Mexico's wealthiest individuals. This is one of the most disturbing findings of this research project as it demonstrates how Mexican public institutions crumble under the power of few private interests. New institutional economics theory teaches us

\footnotetext{
${ }^{216}$ Farfan, Gabriel. Interview by Sean Cornelissen. Unrecorded. Mexico City, November 16, 2015.

${ }^{217}$ The report made by World Bank officials outlining suggestions for Mexico's new mining tax has not yet been made public.
} 
that often times inefficient and unjust institutions, or cultural norms, can continue to exist for millennia, even with globalization and the presence of free markets. ${ }^{218}$ Traditional theories such as neoclassical economics suggest that the presence of foreign investment and the enticement of the free market will eventually persuade developing countries to adopt efficient economic and political policies.

However, the case of mining taxes in Mexico teaches us that the collusion of local business elites and the national government can persist in the face of free trade and an open economy. In fact, the collusion of Mexican business elites with taxation authorities benefitted Canadian mining investors since they are subject to the same tax rate as their Mexican peers given the stipulations of NAFTA. In other words, although Canadian mining investors welcomed the absence of mining royalties throughout the commodity booms, it was their Mexican peers that allowed the favourable taxation regime to persist. It could be argued that Mexico's neoliberal PAN government was the primary reason that taxes were avoided throughout the commodity boom, rather than corruption and collusion. However, the neoliberal argument fails to explain how a single government can justify a completely 'free-market' metal mining industry, while supporting a state-owned monopoly on oil in the same breath. For this reason, it is necessary to take into consideration the effect of historical phenomena and institutions on policy decision-making, rather than to rely purely upon the tenants of the adopted approach (in this case, neoliberalism). The presence of a free market and neoliberal policy framework in Mexico has not and will not alter informal institutions of favouritism and collusion that have been in place for nearly a century, since the end of the Mexican revolution and the birth

${ }^{218}$ Toye, John, "The New Institutional Economics and its Implications for Development Theory" chapter in The New Institutional Economics and Third World Development edited by John Harriss, Janet Hunter and Colin Lewis (London: Routledge, 1995): 62. 49-71 
of the PRI. For that reason, it is important to recognise the agency that NIE gives to formal and informal institutions in order to provide nuance to the neoliberal policy framework that the Mexico has been associated with. Furthermore, NIE teaches us that alternative government regulations and transparency mechanisms can be useful tools to offset historical and unjust informal rules of the game.

The argument presented here is also significant as it directly contests the overbearing assertion in academia that Canadian mining interests (both public and private) have significant influence in Mexico. Interviews with the financial directors of two Canadian mining companies indicated that efforts were made through the Canadian trade commission, CAMIMEX and independently to deter the new mining taxes from being implemented. Similarly, the President of the Canadian mining task force (CMTF) ${ }^{219}$ and the CEO of Goldcorp addressed the Mexican government in an irritated manner regarding the new mining taxes at the Acapulco mining conference. These individuals made it clear that they were unhappy with the recent policy changes, and that any further move in a similar direction would cause them to withdraw investment in the industry. A conversation with an official at the Canadian trade commission revealed that their office had no intent in meddling with Mexican internal politics, and furthermore that CMTF conversations with the Secretary of the Economy were largely futile. All of these indications demonstrate that the attempts of Canadian mining interests to keep a tax policy favourable to their interests in place were largely unsuccessful. They also demonstrate that institutional phenomena concerning the relationship between Mexican elites and Mexican policymakers were more important in policy decision making than foreign influences.

\footnotetext{
${ }^{219}$ The CMTF is a branch of the Canadian Chamber of Commerce in Mexico that promotes Canadian mining interests in Mexico.
} 
Interviews demonstrated that it was Mexican business elites with influence in nearly every sector of the economy that successfully dissuaded SHCP officials from implementing a mining tax throughout the entire commodity boom - not Canadian companies. Empirical data analysis demonstrated that Canadian mining firms earn less than Mexican firms overall, which also suggests that their political leverage is relatively weaker. Finally, substantial literature has shown that the Mexican government has a long history of favouritism with the top earners in Mexico's mining industry. ${ }^{220}$ It is important that authors who write about power relationships in Latin America recognise that Canadian mining interests are likely to have a very different experience in a middle-income OECD ${ }^{221}$ country with a diverse economy, such as Mexico, than in a low-income natural resource dependent economy, such as Bolivia or Guatemala. Some of the articles cited in the literature review which support the Canadian mining imperialism argument do not express an awareness of this distinction. Furthermore, it is important to recognise that although government institutions in both types of Latin American economies may be malleable, one cannot assume that foreign influences are necessarily more powerful than domestic influences. Canadian mining firms, the Canadian trade commission and the Canadian Mining Task Force may have had some influence in avoiding the tax implementation, but their impact would have been negligible compared to that of Slim, Bailleres, or Larrea.

The quantitative and qualitative research that was developed for this thesis demonstrates that the hesitancy of Mexican legislators to impose a mining royalty was due to the political capital of Mexican business elites, rather than that of Canadian mining interests. This recent

\footnotetext{
${ }^{220}$ Wise and Mendoza, "Minería, Estado y Gran Capital en México" (2001), Ángel Tomás Wong Dan "Análsis de Crecimiento y Desarrollo de Grupo México en la Industría Minera", Facultad de Ciencias Económicas y

Empresariales. 15.1 (2015): 104- 113, Strom Thacker, "Big Business, the State and Free Trade: Constructing

Coalitions in Mexico" (Cambridge University Press, New York: 2000)

${ }^{221}$ Organization for Economic Co-operation and Development
} 
history is important as it allows us to better understand who the major players are in the mining industry, the level of autonomy of Mexican policymakers, and how these influences affect economic development outcomes. Looking toward the future, however, the question becomes: what effect will the new mining royalties have on the economic development of Mexico as a nation, as well as specific mining regions? And further, how much does Canadian mining contribute to these public incomes?

Introduction of the 2014 Mining Royalty: The Likely Impacts of Canadian Contributions

The introduction of mining royalties in January 2014 were part of Peña Nieto's broad fiscal reforms which aimed to restructure many public and private activities from pedagogical training for public school teachers to opening up the oil sector to private investment. The introduction of mining royalties, and other aspects of the reform package, initially received support from the all three of Mexico's major political parties which formed the coalition, Pacto por México. Before the reforms were implemented, the right-leaning PAN left the pact, and was soon followed by the left-leaning PRD. Nevertheless, the majority of Peña Nieto's reforms were installed even in the midst of the breaking up of the Pacto por México. The principal changes that were made to the tax administration of mining in January 2014 include:

- $7.5 \%$ royalty tax on revenues earned through the extraction of all metals ${ }^{222}$

- $0.5 \%$ additional royalty tax on revenues from gold, silver, and platinum mining ${ }^{223}$

\footnotetext{
${ }^{222}$ If a firm has net losses from a given fiscal year, they are not required to pay this royalty. For example, Great Panther Silver had more expenses than revenue in 2014 and as a result did not pay the $7.5 \%$ royalty.

${ }^{223}$ I originally hypothesized that this tax was an attempt to get more taxes specifically from Canadian companies, which dominate gold and silver extraction, but interviews suggested that the additional $0.5 \%$ was imposed because precious metals prices rose faster than industrial metals - not because of the companies extracting precious metals.
} 
- The elimination of the IVA tax exemption which formerly gave mining companies the ability to claim most costs incurred during the exploration and development stages once a mine began production ${ }^{224}$

- Payments for land concessions increased 50\% for each year the concession is owned ${ }^{225}$

- Payments for land concessions increased $100 \%$ for each year that a concession holder has no exploration or development activity on the concession after two years of ownership 226

The 2014 mining tax reforms allowed for the creation of the Regional Sustainable Development Fund for Mining States and Municipalities (FDM) ${ }^{227}$ which is financed by $80 \%$ of the government income earned by the two new royalties outlined above. ${ }^{228}$ The remaining $20 \%$ of public income generated by the royalties goes directly to the federal government. According to the document which stipulates the regulations regarding the FDM, $62.5 \%$ of the fund will go to mining municipalities, and $37.5 \%$ will go to mining states to engage in development projects with certain criteria. ${ }^{229}$ The FDM is administered through Committees on Regional Development for Mining Zones (CRD), which is explained more in-depth below. ${ }^{230}$

\footnotetext{
${ }^{224}$ The elimination of this tax was particularly important for companies which began production shortly after the new tax laws were implemented as they had reimbursement of all preliminary costs in their calculations. This tax may also have a significant effect on prospective investors as junior companies with little capital will have less incentive to choose Mexico as a destination for opening their first mine.

${ }^{225}$ In 2010 the Auditor General's office produced a report stating that concession payments (as low as \$5 MX pesos per hectare) were lower than the costs associated with administrating the concessions. The report stated that not only was the federal government losing money administering concessions, but less than $1 \%$ of concessions were invigilated by an official from the Secretary of the Economy because of a lack of funds. The SHCP director responsible for drafting the mining tax reform stated that when he began working in 2010 there were only four employees responsible for administering nearly 3,000 mining concessions. My research has led me to believe that these are the principle reasons why concession prices were increased.

${ }^{226} \mathrm{An}$ interview revealed that during the commodity boom there was an issue of companies buying concessions and waiting for prices to rise even further, leaving the land in an unproductive state. The major issue with this behaviour is that the land cannot be used for other industrial purposes while it is concessioned for mining.

${ }^{227}$ In Spanish, Fondo para el Desarrollo Regional Sustentable de Estados y Municipios Mineros (FDM)

228 "Reglamento de la Ley Minera", Última reforma publicada Diario Oficial de le Federación, 31 de octubre 2014

${ }^{229}$ Ibid.

${ }^{230}$ Ibid.
} 
Canadian firm participation in the Regional Sustainable Development Fund for Mining States and Municipalities (FDM) will of course be limited to the amount of revenue Canadian companies earn in the relevant constituencies. Since Mexico has a free trade agreement with Canada, companies from both countries are expected to contribute in an identical manner to the development fund. Because there is no objective distinction between how Canadian and Mexican firms finance the FDM, the following analysis is based on how the fund works, and what this means for Mexico's economic development. As a reminder, Canadian firms are responsible for roughly $40 \%$ of all metal mining revenue in Mexico. Therefore, roughly $40 \%$ of the FDM's initiatives will be funded by Canadian firms, since contribution to the FDM is based on a firm's total revenues.

It is my contention that creating mining royalties to generate more government revenue should have a more important effect on economic development compared to the impact of employment and value added products and services. However, a positive effect from taxation on economic development depends in large part on how those funds are spent by public authorities. Data gathered from various sources will be presented in order to provide insight into how and where the mining tax is expected to be spent. The common denominator in all of the present problems (and predictable future issues) regarding the disbursement of the FDM is the widespread existence of institutions that enable malpractice and corruption.

It should be mentioned that the new royalties and changes in concession payments are in addition to the $30 \%$ corporate income tax that all companies are required to pay in Mexico. Other existing regulations included municipal property taxes, employee benefit requirements, and the 
requirement of a management office in Mexico. ${ }^{231}$ An exact calculation of the amount a company pays in taxes depends upon many factors such as the size of the concession, whether the company has net gains or net losses, when the company uses various types of tax reimbursements, whether input products are imported or bought in-country, and many other factors. In comparison with other Latin American countries where Canadian mining firms were heavily involved pre-2014, Mexico provided one of the most, if not the most, competitive tax regime with all factors considered. Two of the world's top investment consultancy firms, Deloitte and PwC, highlighted the particular attractiveness of Mexico's laissez faire taxation regime in the mining industry in recent reports. ${ }^{232}$

Each state with a mining industry now has a Committee on Regional Development for Mining Zones (CRD), which administers FDM funds and approves project proposals for municipal governments in its jurisdiction, as well as the state government. The committee consists of the following representatives: one state government official, one municipal government official, one mining company representative, one indigenous or agricultural community member, and a secretary. ${ }^{233}$ Many interview subjects saw the new committees as an opportunity for different stakeholders to work together on a regular basis, which could improve communication and reduce social conflicts. This finding suggests an optimistic outcome of the CRDs. However, the membership of the committees could prove to be counterproductive in creating efficient development projects because the committees seem to be unrepresentative of the population they are meant to serve. Only one of five committee seats is reserved for an

\footnotetext{
231 Taxation and Investment in Mexico 2014, Deloitte Touche Tohmatsu Limited, accessed January 12, 2015 on http://www2.deloitte.com/content/dam/Deloitte/global/Documents/Tax/dttl-tax-mexicoguide-2014.pdf.

${ }^{232}$ Mining Industry in Mexico, Deloitte, May 2012. Corporate Income Taxes, Mining Royalties and other Mining Taxes: Global Mining Industry Update 2012, PwC, June 2012. ${ }^{233} \mathrm{Id}$.
} 
'indigenous or agricultural community member' which could prove to be problematic considering that he or she is the only individual with an in-depth idea of what the population needs most in order to develop economically. This situation may be problematic as it could result in the development of projects which do not serve local communities; but instead serve other populations such as urban centres where municipalities are based.

Importantly, the fund can only be used to develop "physical infrastructure with a positive social, environmental, and urban development impact" such as: school or hospital construction and remodelling, highway and public transportation maintenance, landfills, improving air quality, reforestation, urban mobility, river restoration, etc. ${ }^{234}$ One issue with these criteria is that they allow for the construction of new public institutions, but do not permit for the FDM to pay for doctors, nurses, or teachers. The construction of infrastructure without a mechanism to make the infrastructure sustainable is a common problem with development initiatives, which should be an important consideration for FDM committees. A second concern with the destination of the funds is that most Canadian mines are located in very rural areas, so "urban development impacts" or "urban mobility impacts" do not seem to be relevant development projects for the poor residing in mining regions. The official regulations regarding the FDM which outline what the funds can be spent on, as well as the unawareness of interviewed government officials of these rules, raises considerable concerns in regards to the trajectory of the development fund.

My fieldwork revealed that no development project funded by the FDM had been launched as of October 2015, nearly two years after the tax changes were implemented. The Zacatecas FDM committee had been formed and met on three occasions during this nearly two

${ }^{234}$ Ibid. 
year period, however no development project had been approved by the committee at the time of the interview with the Director of Mines in Zacatecas. ${ }^{235}$ An interview with the Director of Economic Development in the municipality of Morelos, Zacatecas, where one Canadian and one Mexican owned mine are located, revealed that the municipality's development projects were sent to the committee for approval on October $13,2015 .{ }^{236}$ The director admitted that the process for receiving FDM funding and submitting development projects has been slow, but he stated that it is normal for such processes to be lengthy in Zacatecas as government bureaucracy generally operates more slowly in rural states. The slow rate of FDM project developments is damaging to the fund's beneficiaries, as well as Canadian mining companies. As previously mentioned, some Canadian firms claim to have reduced CSR payments and are therefore anxious to demonstrate 'social responsibility' to local communities via projects generated from the new mining taxes.

The lethargic nature in which FDM committees, the SHCP and municipalities have been developing FDM projects may reflect a cultural gap in how the Mexican government and Canadian mining companies view time as an institution ${ }^{237}$. On a similar note interviews revealed that when firms were entitled to IVA tax reimbursements, before the reforms took place, it sometimes took Mexican tax officials more than a year to disperse these funds to Canadian companies. It was difficult for financial directors of Canadian firms to explain to their superiors how long this process took, and companies often expected the reimbursement to arrive in a

\footnotetext{
${ }^{235}$ Magdallenes, Juan de Dios. Interview by Sean Cornelissen. Unrecorded. Zacatecas, October 14, 2015.

${ }^{236}$ Reyes, Gilberto and Fajardo, Isaac. Interview by Sean Cornelissen. Unrecorded. Morelos, Zacatecas November 14, 2015.

${ }^{237}$ As a reminder informal institutions, such as time, are considered to have considerable effects on economic development. In other words, it is not only formal institutions such as laws and rules that effect economic decision making of the private actors, but also informal institutions such as time, family structures, and religion.
} 
timely manner. As mentioned earlier, before Canadian firms began to hire Mexican managers, there were cultural misunderstandings in the manner in which Canadian companies began exploration processes before speaking with local populations. New institutional economics stresses that the scenarios described here arise as a result of a lack of knowledge (on both sides) in developed - developing world relationships. ${ }^{238}$ For North, different cultural approaches to time, relationships and communication can impose a significant transaction cost when knowledge regarding these phenomena is not perfect. He stresses that recognising these gaps in knowledge and attempting to mitigate misunderstandings will become increasingly important in the years to come as the world globalizes and technology advances. ${ }^{239}$ Understanding different cultural approaches to various phenomena (such as time) is crucial to developing a more efficient mining industry for Canadian investors, and a mining industry that generates more positive impacts for the Mexican economy. My research revealed that these understandings are improving, but there is still a significant gap to be filled.

The interview in Morelos, Zacatecas demonstrated that FDM funding caused the municipality's budget to double in $2015 .{ }^{240}$ Data collected for this research project shows that in 2015 about $\$ 13.5$ million CDN was due to the municipality of roughly 10,000 inhabitants based on the mines' 2014 revenues. ${ }^{241}$ The Director of Economic Development of Morelos informed me that funding for municipal administration remained the same, even though the municipality's revenue doubled as a result of funding from the FDM. The municipality of Morelos, and many others in a similar situation, will be administering a budget twice as large as ever before, but with

\footnotetext{
${ }^{238}$ Toye, John, "The New Institutional Economics and its Implications for Development Theory": 62.

${ }^{239}$ North, Douglass C. "The Adam Smith Address: Economic Theory in a Dynamic Economic World": 9.

${ }^{240}$ Reyes, Gilberto and Fajardo, Isaac. Interview by Sean Cornelissen. Unrecorded. Morelos, Zacatecas November 14, 2015.

${ }^{241}$ Appendix 1: Mining Production in Mexico, 1996-2014.
} 
the same amount of personnel. A situation of overworked, unsupervised and underqualified employees in a rural municipality with a massive budget should be reason to raise concern in regards to how the FDM will be spent. However, the government document which describes the FDM does not mention any supervisory mechanism or monitoring board specific to this initiative. ${ }^{242}$ Government officials at the municipal and state levels, as well as a Canadian copper company representative, were also unaware of any monitoring efforts in place to supervise the disbursement of funds. It is clear that projects must be approved by the FDM committees before they can begin, but once funds have been allocated to certain projects there does not seem to be any overseeing body to monitor how budgets are utilized.

Mexico’s largest gold mine, Peñasquito, is located in the municipality of Mazapil, Zacatecas with a largely rural population of $17,813 .^{243}$ Mazapil is of particular interest not only because it will receive more funding from the FDM than any other municipality, but also because the funding will be derived entirely from Goldcorp, a Canadian company. In 2015 the municipality’s FDM budget should have been roughly $\$ 93.5$ million CDN. ${ }^{244}$ This amounts to over $\$ 65,000 \mathrm{MX}$ pesos for each citizen, or almost triple the minimum wage in Mazapil - a municipality with a $72 \%$ poverty rate. ${ }^{245}$ Considering that the majority of Mazapil residents do not have a sufficient income for all of the basic necessities, it seems that an additional $\$ 93.5$ million CDN per year to the municipal budget could create accountability problems. My reasoning for this belief is that it seems unreasonable for Mazapil to properly manage such a

\footnotetext{
242 "Reglamento de la Ley Minera”, Última reforma publicada Diario Oficial de le Federación, 31 de octubre 2014.

243 "Censo de Poblacion y Vivienda", INEGI, http://www.inegi.org.mx/sistemas/consulta_resultados/iter2010.aspx?c=27329\&s=est, accessed February 4, 2016. 244 Appendix 1: Mining Production in Mexico, 1996-2014.

245 "Medicion de Pobreza: Resultados de Pobreza por Municipio", CONEVAL, http://www.coneval.gob.mx/Medicion/MP/Paginas/Anexo-estad\%C3\%ADstico-municipal-2010.aspx, accessed February 4, 2016.
} 
massive budget with no additional personnel or supervision; especially when those working on the expensive projects are living in poverty.

Before the FDM was adopted, the small municipality of Mazapil made news in 2014 when its public works department was found to have been purchasing poor quality construction materials at elevated prices from a friend of the mayor. ${ }^{246}$ The individual selling the subpar materials for municipal projects, Robles Santos, was later offered the position of subdirector of the public works department. This recent situation speaks to how institutionalized nepotism and collusion can be in local governments in rural Mexico. The literature review section described how influential corruption and collusion are in Mexican business culture. Industry leaders in Mexico are well aware of how institutionalized collusion is in Mexico; something that would have been difficult to ignore given the absence of a mining tax throughout the entire commodity boom. Indeed, the international community recognises the weaknesses of Mexico's institutions and their inability to effectively fight against corruption and collusion. ${ }^{247}$ Creating a specific and effective monitoring board (a formal institution) for the disbursement of FDM funds could be an effective measure to reinforce responsible business behaviour and transparency (informal institutions).

The FDM will distribute funds collected from mining royalties to less than 85 of Mexico's 2,438 municipalities, as these are the only municipal districts with metal mining

246 "Aviadores y proveedor de Mazapil tienen tomada la presidencia" Zacatecas en Imagen, February 25, 2014, http://www.imagenzac.com.mx/nota/aviadores-y-proveedor-de-mazapil-tienen-23-20-06-2k, accessed February 4, 2016.

247 "Mexico Among The World's Most Corrupt Nations In 2014, New Report Says", Forbes Magazine online, December 11, 2014, http://www.forbes.com/sites/doliaestevez/2014/12/11/mexico-among-the-worlds-most-corruptnations-in-2014-new-report-says/\#6378e4c73258, accessed February 4, 2016. 
activity. ${ }^{248}$ Therefore, the new mining tax laws will certainly have a large and noticeable effect on the annual revenue for certain municipalities, but over $95 \%$ of Mexico's municipal districts will not be affected. The remaining $37.5 \%$ of the FDM will be distributed amongst 14 of Mexico's 32 states. ${ }^{249}$ The public revenue for states will be less significant than it will be for municipalities, since state revenues are typically more diverse, and municipal revenues are considerably smaller. Furthermore, as previously mentioned, Canadian firms' contribution to the FDM will be approximately $40 \%$ of the fund's entire budget.

The new mining royalties and related policies are a step in the right direction as they aim to take advantage of Canadian mining investment for Mexico's economic development. Policy decisions regarding the mining royalties outlined above have created a tax system that will require Canadian firms to contribute significantly to the development of mining regions. However, given that Canadian mining firms produce less than 1\% of Mexico's GDP, their contribution to publicly funded development will not be grandiose. It is clear that the fund which has been created to channel new public revenue into local development projects has some weaknesses in regards to financial accountability, applicability to local populations, and its overall reach. Furthermore, as Puyana and Moreno (2015, forthcoming) pointed out, the new mining tax legislation is good policy, but it was legislated too late after metals prices had already fallen. Since public income is likely the manner in which Canadian mining investment can most effectively aid Mexico's economic development, it is crucial that the disbursement of these funds

\footnotetext{
${ }^{248}$ Data collection showed that there are 86 metallic mines in Mexico in total. Two of those mines are known to be in the same municipality: Appendix 1: Mining Production in Mexico, 1996-2014.

${ }^{249}$ Appendix 1: Mining Production in Mexico, 1996-2014.
} 
is done efficiently and in a transparent manner. Throughout the discussion of the FDM I have provided insight from NIE, which explains why institutions are relevant in these transactions.

Using NIE as a lens to examine Canadian mining in Mexico provides a space for understanding why free trade (created by NAFTA) and open investment (created by the Foreign Investment Law) are not sufficient mechanisms to induce economic development. Neoliberal and neo-classical economics, which support these policies, are similar in that they do not provide sufficient recognition of institutional factors which affect real-life economic outcomes of the mining industries. Some examples of these institutional factors include: cultural approaches to conducting business and the sale of land, the lack of knowledge transfers that are associated with mining, the lack of investment in industries with linkages to mining (for various reasons mentioned above), political incentives to create (or not create) regulations and taxations mechanisms, and the effects of entrenched corruption and collusion among public and private sector actors. By applying NIE in this thesis, I was able to provide a nuanced appreciation of these and other institutional factors that affect the economic development consequences of Canadian mining in Mexico. Recognising the power of informal institutions, predicting problems that could arise from them, and creating formal institutions to mitigate these issues is absolutely crucial for Canadian mining to effectively impact Mexico's economic development.

In sum, Canadian mining production has marginal effects on economic development in Mexico at the national level, but seems to have some important, limited, positive economic effects at the local level. Benefits at the local level include access to formal and well-paid employment, increased municipal funding from the FDM since 2014 and some forms of lowwage backward linkages in local regions. However, the inability for Canadian mining dollars to 
be converted into economic development at a national level during the commodity boom was limited by: new technologies that reduced employment, few backward linkages to high-paid and large-scale industries, nearly inexistent forward linkages for post-production goods, the absence of a mining-specific tax and a relatively small contribution of Canadian mining firms to Mexican GDP. Throughout the above section I have made the argument that formalizing certain institutions, and creating formal monitoring and transparency mechanisms, could be the key to help 'break' historical patterns of nepotism, collusion and cultural misunderstandings between Canadian firms and the Mexican mining actors. Doing so could allow Canadian firms to more effectively contribute towards Mexico's economic development on both the local and national levels. 


\section{Chapter 5}

\section{Conclusion:}

\section{Looking Towards the Future}

The previous chapter utilized my qualitative and quantitative findings to develop an analysis of the effects of Canadian mining production on Mexico's economic development. I also laid out how new institutional economics (NIE) can be used to understand how institutions affect the ability of Canadian investment to encourage economic development through three specific indicators: employment, value added products and services, and public revenue. This concluding section will briefly re-emphasize the primary arguments of this thesis, and will also suggest some limitations of using NIE as the primary theory to understand the subject. Following this, I will outline some policy suggestions that could potentially help to shape the Mexican mining industry to be more conducive at harnessing Canadian FDI for domestic economic development purposes.

Through a predominantly national-level analysis of the Mexican mining industry, this thesis attempted to better understand the economic development implications of Canadian mining FDI in Mexico. Throughout the commodity boom Mexico was a top destination of global mining FDI as a result of its metal-rich geological composition, high metals prices, and the complete absence of a mining-specific tax. In addition to being a top destination for investment during the commodity boom, Mexico is also currently the world's largest producer of silver, and is one of the top ten producers of over 15 other minerals including copper, zinc and gold. When metals prices reached their peak in 2012, foreign and domestic companies in Mexico produced over \$16 billion worth of metals. During the period under analysis (1996-2014), Canadian mining firms were the most important global investors in mining exploration and production, 
with Mexico being a major recipient of Canadian investment dollars. By the end of the commodity boom, in 2013, Canadian firms dominated $73 \%$ of mining investment in Mexico. ${ }^{250}$ Considering the globally renowned importance of both the host country (Mexico) and the chief investing country (Canada) in the international mining industry, relatively little is known about how Canadian investment has affected Mexico’s economic development.

As described in the literature review, much emphasis has been placed on the role of Canadian firms in Mexico in regards to social and environmental conflicts. These works are very important, especially considering the precarious nature of the mining industry with respect to the environment, and the violent nature of the social conflicts that some Canadian firms have been involved in. In order to provide more context to these debates, I decided to focus on the effects that Canadian firms have had on Mexico's economy in order to determine if Canadian mining FDI is useful to Mexico's development from an economic perspective. However, before determining if and to what degree Canadian mining production has helped Mexico's economic development, it was necessary to first determine the relevance of Canadian production in the Mexican context. My empirical analysis determined that the entrance of Canadian mining firms into the Mexican economy effectively eliminated the industrial monopoly that was previously harnessed by Mexico's three richest people (Carlos Slim - Minera Frisco, Alberto Bailleres Industria Peñoles and Germán Larrea - Grupo México). The data demonstrated that by 2012, Canadian firms were responsible for roughly $40 \%$ of Mexico's metal mining production value.

Monopolies are considered to be inefficient for market growth, encourage general malpractice and discourage transparency as a result of a lack of competition. ${ }^{251}$ Creating a more

\footnotetext{
250 “Situación de la Minería en México en 2014” Reporte de Situación 2015, CAMIMEX, 15.
}

${ }^{251}$ Problems with monopoly article 
competitive business atmosphere among mining firms in Mexico was probably an important factor in keeping various mining industry practices in check throughout the commodity boom, such as: safety and environmental standards, use of more efficient technologies, and increasing exploration projects and national reserves. Two interviews with Mexican officials at the state and federal levels indicated that Canadian mining firms have had a positive effect by introducing new environmental and labour standards. ${ }^{252}$ Furthermore, the UNCTAD document previously cited also found a positive correlation between the presence of foreign mining firms and an improvement in environmental and labour standards in the developing countries it analysed. ${ }^{253}$ Canadian production can be seen as being beneficial from a market competition perspective. However, my analysis of its effect on Mexico's regional and national economic development provided a different outlook.

Employment from Canadian mining firms in Mexico was determined to be very important for certain rural areas, where high wages for general labour is otherwise uncommon. Furthermore, the fact that employment in Canadian mining was in the formal labour market (rather than the informal labour market) is also a positive as it encourages safe labour practices and employer accountability. However, considering the amount of revenue that Canadian firms made during the commodity boom in comparison with the amount of employment that was generated, it was determined that employment was trivial. The main reason that employment at Canadian mines was low, especially considering the massive revenues that were earned, is that new technologies and open-pit mining styles meant that less labour was needed than during previous periods. Although the same holds true for most large-scale mining companies across the

\footnotetext{
${ }^{252}$ Interview with state and with international investment head guy
}

${ }^{253}$ UNCTAD, 145. 
globe, this thesis determined that employment in Canadian mining production was not a very significant driver of economic development in Mexico.

Value added linkages in the economy were also determined to be negligible in terms of both backward and forward linkages, despite Mexico's large economy and its specialization in manufacturing. Although this is common for many other developing countries with a significant mining industry, I indicated that more effective efforts aimed at creating institutions to help facilitate innovation could help to change this trend. Since most Canadian firms operating in Mexico are junior companies, it is unlikely that they will add significant value to the Mexican mining industry without encouragement from the Mexican government. Some ideas on how to encourage innovation and investment related to the mining industry within Mexico's borders by creating and utilizing formal and informal institutions are provided below.

Mexican public revenue received from Canadian mining firms throughout the commodity boom was minimal in comparison with other regional hosts of mining FDI, largely due to Mexico's complete absence of a mining-specific tax during the period. Interviews suggested that it was likely Mexican mining giants that blocked the installation of mining royalties during this period, rather than Canadian mining interests. Therefore when analyzing the effect of Canadian production on Mexico's economic development through provision of public revenue, I determined that Canadian firms contributed relatively little as a result of the institutionalized nepotism and collusion that have been in place in Mexico since long before the entrance of Canadian firms. Although significant mining royalties have been installed since 2014, the institutions that are in place to monitor and guide the royalty-funded development projects raise 
concern in regards to oversight, collusion and corruption of these funds. Again, some policy suggestions to mitigate these potential future issues are provided below.

More broadly, I have argued that Canadian firms contributed to Mexico's economic development during the commodity boom, but not as much as they could have considering the massive production values of their mines. I have suggested that it is unlikely that employment levels could improve given the context of rapid technological evolution. On the other hand, I have suggested that Canadian firms have the potential to contribute more substantially in regards to value added products and services; but are unlikely to do so without formal institutionalized encouragement from the Mexican government. Finally, it is necessary to restate that Mexico currently has a considerably high mining royalty, but the fact that it was not installed until 2014 is likely due to institutionalized public-private collusion with Mexican mining firms.

Canadian firms and the Canadian government can participate in helping to shape Mexico's mining industry to be more conducive to economic development (see Introduction). However, the Mexican government has a better understanding of its own informal institutions, and it has the legal capacity to create and enforce formal institutions which can foster long-term economic development. I suggest that future research regarding Canadian mining operations in Latin America give more agency to host countries, instead of generating a limited analysis on the impact of Canadian influences. Doing so would be more conducive to positive change for recipients of Canadian mining investments as it provides host countries with the ability to take action, rather than become bystanders in their own development processes.

One of the weaknesses in my approach to this thesis is that I focused extensively on the implications of NIE on the subject being analysed, and did not include other theories in my 
analysis section. Sociological institutionalism, historical institutionalism and rational choice institutionalism also provide insights into the value of institutions, as described by Hall and Taylor (1996). ${ }^{254}$ A neo-structuralist analysis could have also provided some insight regarding the formal institutions that I suggested need strengthening. Utilizing these related theories could have provided a more encompassing understanding of Canadian mining in Mexico as it would have facilitated a discussion regarding environmental issues, social conflicts, and human rights issues. The discussion of the work of previous scholars in the literature review helps mitigate this gap in my research. Nevertheless, utilizing these additional institutionalist approaches may have offered a different perspective to this research.

Another weakness of focusing on NIE, rather than the more commonly used neoliberalism theory, is that my analysis was focused more heavily on institutional phenomena rather than ideological positions. Examining Canadian mining production in Mexico through the lens of neoliberalism would have likely led to altered conclusions regarding why certain decisions were made by elites and policymakers. For example, in determining why royalties were not installed during the commodity boom I could have concluded that the PAN's neoliberal government advocated for limited government intervention and encouragement of foreign investment. This assertion would have been accurate and would likely have led to a different analysis. However, I decided to use NIE in order to contrast assertions made by neoclassical and neoliberal advocates because the primary tenant of the theory states that these traditional economic theories fail to grasp the significance of formal and informal institutional phenomena in real-life economic events. Nevertheless, an inclusion of neoliberalism in the analysis section

\footnotetext{
254 Peter A. Hall and Rosemary C. Taylor, "Political Science and the Three New Institutionalisms", paper presented to MPIFG Scientific Advisory Board (1996): 5-25.
} 
of this paper (rather than only using NIE's critique of neoliberalism) may have provided some insightful contrast.

A conference hosted by the World Bank on natural resources, institutions and public revenues found that 'best practices' are usually known in developing countries, but rarely executed. ${ }^{255}$ In Mexico, Peña Nieto's mining action plan acknowledges the need for improving institutions surrounding the mining industry (especially those related to the concession process), which seems promising. However, within the specific objectives of the action plan, no mention is made regarding transparency, property rights, or government monitoring. ${ }^{256}$ The following policy proposals are simple ideas that I have determined may be conducive to generating economic development from Canadian mining production in Mexico:

1. Create incentives for Canadian firms to use their metals for the manufacturing of postproduction goods in Mexico by discouraging the export of crude metals.

Although this policy would apply chiefly to industrial metals (copper, zinc, lead and iron ore products), alternative uses for gold and silver in green technologies are also becoming more common. One way to achieve this goal would be to introduce a sliding-scale export tax on extracted ores, processed ores, and processed metals depending on the amount of value-added inputs of each of the products. The exact tax percentages would need to be determined by an indepth industrial study, but the idea would be that extracted ores would be most heavily taxed (around 10\%), followed by processed ores and processed metals (between $2 \%$ and $5 \%$ ), and

\footnotetext{
${ }^{255}$ World Bank and Norad Conference: "From Curse to Development: Natural Resources, Institutions and Public Revenues" Oslo, Norway (2011): 17.

256 Acuerdo del Programa de Desarrollo Minero 2013-2018, Diario Oficial, September 5, 2014 :

http://www.dof.gob.mx/nota_detalle.php?codigo=5344070\&fecha=09/05/2014.
} 
manufactured goods using Canadian metals would not be taxed at all, or could possibly even receive tax credits. This strategy was adopted by Argentina's previous government which taxed unprocessed metals between 5\% and 10\%. ${ }^{257}$ Implementing such a tax could be complicated considering Mexico's free trade agreement with Canada and other countries, however Argentina also had free trade agreements and international investment agreements with other countries when it implemented this suggested policy. Mexico could face challenges at international tribunals by implementing this policy, but the effects of the policy may outweigh the risk of arbitration.

2. Create an incentive for manufacturing firms that fabricate large industrial machinery for mining to engage in production in Mexico.

Mexico has the advantage of being in a free trade zone with Canada and the U.S., which permits foreign firms to more easily begin production there. Mexico is already a host to many large automobile manufacturers including GM, Ford, and Volkswagen. If Mexico became a host to large machinery manufacturers it would be able to provide machines to mining firms in Mexico, other Latin American countries, and globally. This would not only create jobs and public revenue for Mexico, but the plants would also provide employment to engineers, software experts, senior administrators and other high-level positions. Mexico has the advantage of already having many buyers of large machinery actively producing metals in the country, with other mines entering production in the coming years.

\footnotetext{
257 “Mining Taxes for Argentina”, Price Waterhouse Coopers website, accessed March 28, 2016: http:/www.pwc.com/gx/en/industries/energy-utilities-mining/mining/territories/argentina.html\#footnote-14.
} 
In order to accomplish this goal, Mexican policymakers could re-establish the IVA tax exemption that was abolished by Peña Nieto's reforms. As a reminder, the IVA tax exemption formerly gave mining firms the ability to claim expenses spent during the exploration and development stages of a mine on their income taxes. Mexico could reinstate the IVA tax exemption but make it applicable exclusively to goods and services that are bought domestically. This would be more advisable than taxing the importation of foreign goods, because such a policy would be more easily opposed in an investment dispute. Making the IVA tax exemption specific to domestically produced goods would encourage Canadian firms to purchase goods and services locally.

3. In regards to the Mining Development Fund (FDM), efforts should be made as soon as possible to implement monitoring mechanisms for (A) the effectiveness and sustainability of FDM projects and (B) how FDM funds are spent.

In order to do this, a small monitoring team could be established which has a close relationship with the committees in each of the mining regions (CRDs), reviews the projects over time, and calculates if the prices paid for services and labour are reasonable in the context of each of the states and municipalities.

4. With regards to the social and environmental conflicts which have been written about by other academics, an alternative approach to deciding upon concession rights could be appropriate.

At the Annual Mining Conference in Acapulco that I attended, Maria Amparo Rodriguez demonstrated how companies make proposals to municipalities in different European countries 
to develop controversial wind farms. According to Ms. Rodriguez, this process began as a result of locals complaining about disruptions to their daily lives because of a large influx in windmills. For mining, this would mean that if metals were discovered in a certain region, different mining companies would have to create competing proposals for the right to extract the metal. These proposals could include: independent environmental assessments based on their proposal, monetary amounts that would be awarded to the municipality and land owners, social projects, and economic benefits for locals. I understand that this proposal is unlikely to be adopted given Mexico's current political climate, but it provides a possible compromise that Canadian mining interests and local mining protestors could work with.

The findings and analysis provided in this thesis are relevant to the current context of mining in Mexico as they provide an understanding of the important influences of the mining industry on Mexico's economic development. The investigation could also be applied, in a general sense, to other major mning countries in Latin America and throughout the developing world. More than anything, this thesis has advocated for a nuanced approach to studying FDI in extraction industries with the aim of understanding the totality of the effects extraction investment on local populations. It is hoped that moving forward more scholars will give agency to the domestic institutions that influence a country's development, while at the same time maintain a critical view of the power held by foreign actors. 
Appendix 1: Mining Production in Mexico, 1996-2014*

*This appendix is in the form of an Excel document with many worksheets and for that reason is not included in the thesis. If you would like further information regarding Appendix 1 please email the author at cornelissensean@gmail.com. 
Appendix 2: Un Análisis Preliminar de la Producción Minera de Empresas Canadienses en México

Por: Sean Cornelissen

$\underline{\text { Figura } 1}$

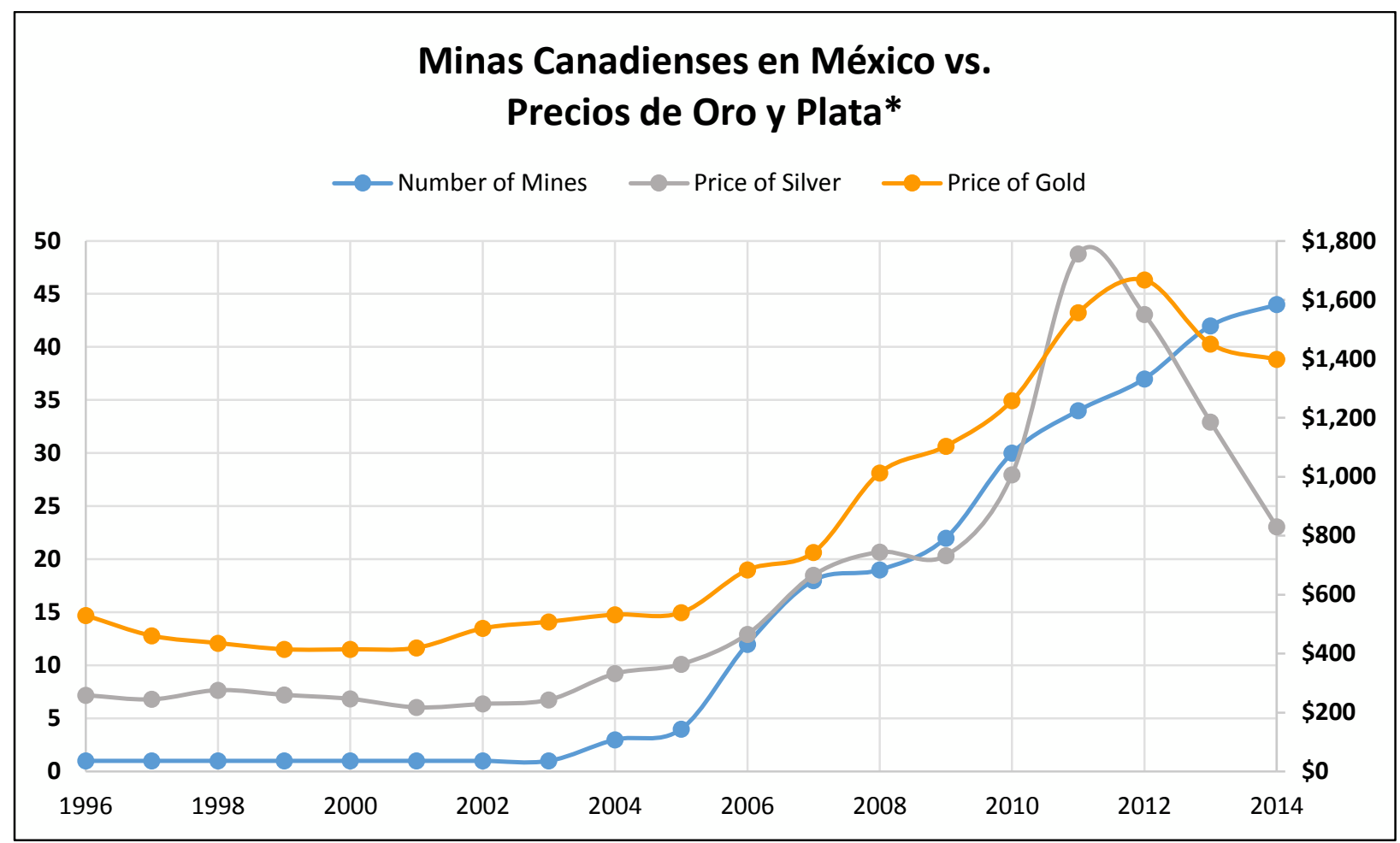

*Precios de oro y plata visualizados en dólares canadienses (CAD) y basados en precios promedios del London Metal Exchange (LME)

*Precio de plata visualizado a 40 veces su valor real para proveer consistencia en el gráfico

La Figura 1 ilustra que cuando los precios de oro y plata estaban relativamente bajos a finales de los 1990s y la primera mitad de los 2000s, existían muy pocas minas de metales preciosos pertenecientes a empresas mineras canadienses en México. Cuando el precio de estos metales empezó a elevarse, se incrementó también el número de estas minas. Uno de los factores más importantes que dio el puntapié inicial a la entrada de empresas canadienses fue la adquisición de la lucrativa mina El Sauzal por parte de Goldcorp en 2005. Antes de entonces, las pocas empresas canadienses que habían eran empresas junior operando minas con muy poca producción. La compra de El Sauzal llamó la atención de otras empresas canadienses debido al tamaño de Goldcorp, su antigüedad en la industria y la gran producción de la mina adquirida. Aquí está un análisis más detallado de empresas canadienses con una presencia en la minería mexicana.

Hasta hace poco, México había sido considerado por muchas agencias consultoras como el destino número uno para la inversión minera en América Latina debido a la ausencia completa de regalías y su riqueza mineral. Estos factores, combinados con el incremento en los precios internacionales de los metales, facilitaron a la entrada de cada vez más empresas canadienses en 
producción en el país. Se puede observar que el número de minas bajo control de compañías canadienses se incrementó en sincronía con los precios de plata y oro. El Cuadro 1 muestra que cada una de las 30 empresas canadienses actualmente en producción en México tiene una presencia significativa en la producción de plata y/o oro.

Generalmente se considera que los precios de oro son más indicativos de la inversión minera y tendencias del mercado minero que los precios de plata, pero es importante incluir ambos de los metales en un análisis de México porqué en la última década México ha sido alternativamente el primer y segundo productor de plata al nivel mundial. Durante el periodo representado en Figura 1, el oro y la plata se han como los metales más importantes dentro de la producción minera mexicana.

Asimismo, como ilustra Figura 1, el número de minas controladas por empresas canadienses siguió creciendo después de 2011/2012 aún cuando los precios del oro y la plata empezaron a caer. La explicación de este fenómeno radica en que las inversiones canadienses en exploración y desarrollo en México son aún más impresionante que su participación en producción. Sin embargo, considerando que la mayoría de propiedades en exploración nunca llegarán a ser explotados, las propiedades que son rentables toman años para desarrollar lo cual significa que algunas minas fueron desarrolladas cuando los precios aún eran altos entrando recién en producción cuando los precios comenzaron a declinar.

Los precios de oro y plata siguen siendo más altos que fueron hace una década, pero muchos analistas consideran que mientras que las economías de EEUU y otros países empiezan a recuperar, la inversión en estos metales preciosos seguirá disminuyendo (Financial Post, 2015). Los mejoramientos en tecnología y los costos más bajos de energía hacen creer a muchos que la producción va a continuar creciendo aún cuando los precios sigan bajando, lo que en el mediano plazo resultará en un exceso de en la oferta, provocando que precios se reduzcan aún más en el largo plazo (Bloomberg, 2015).

Sin embargo, otros expertos consideran la crisis financiera griega y a la demanda siempre creciente de oro y plata en China e India (los consumidores más grandes del mundo) como razones para creer que la demanda seguirá creciendo y que los precios van a mantenerse relativamente altas (Bloomberg, 2015). Además, inversionistas privados normalmente hacen inversiones en oro buscando estabilidad en largo plazo ya que su precio tiene una correlación débil con otros productos. Esto significa que movimientos en los precios en el corto plazo, ejemplificados por la caída ocurrida en los últimos dos años, no necesariamente será suficiente para intimidar a los inversionistas (World Gold Council, 2015).

En cualquier caso, las reformas al impuesto minero implementadas en enero 2014 probablemente asustarán a nuevas inversionistas y desalentarán a los actores a invertir en el desarrollo de minas. Las reformas de impuestos introducirán regalías al país por primera vez en más que tres décadas, reducirán los impuestos deducibles para empresas en la fase de exploración, e incrementarán impuestos de las propiedades. Como la minería metálica sólo representa el 3\% del PIB de México, no es probable que inversionistas canadienses ni el gobierno canadiense tendrán una influencia significa en las decisiones al nivel federal del gobierno de México. Si los 
precios de metales siguen cayendo, es probable que México perderá su lugar como destino número uno para inversiones mineras en la región pues inversionistas tendrán pocos incentivos para continuar en ese país.

\section{Figura 2}

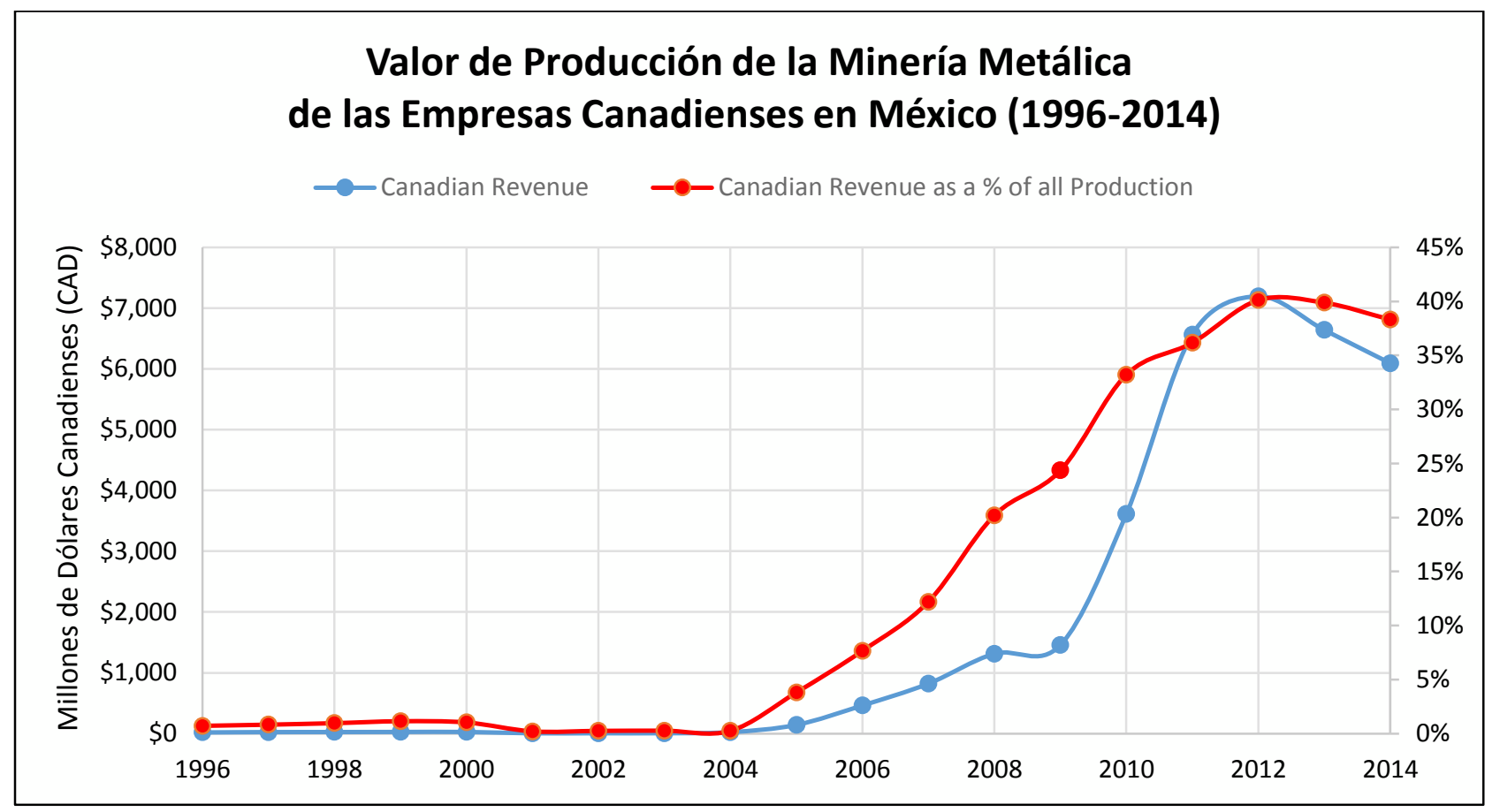

Antes de la firma de la Ley de Inversión Extranjera en 1996, empresas canadienses tenían muy poca influencia en la minería metálica mexicana. Figura 2 ilustra que la producción canadiense en el sector minero metálico en México era casi insignificante hasta hace una década. Durante el periodo que siguió la aprobación de la Ley de Inversión Extranjera, las empresas canadienses empezaron a invertir en México debido a la ausencia completa de regalías sobre la producción y los beneficios ofrecidos por el Tratado de Libre Comercio de América del Norte (TLCAN), ratificado en 1994.

Aunque estos dos factores influenciaron la inversión extranjera proveniente de Canadá en exploración que luego se convertirá en producción, fueron los altos precios durante el auge de commodities de los 2000s que realmente facilitó su entrada agresiva. Desde el 2005, la participación relativa de las empresas canadienses se incrementó muy rápidamente para pasar de menos de 5\% a más de 40\% en un periodo de menos de 10 años. Desde 2003 hasta 2013 el valor de producción de empresas canadienses incrementó de CDN \$6 millones a CDN \$7.2 billones.

La Figura 2 demuestra que de 2010 a 2012 la participación relativa de las empresas canadienses se incrementó menos rápido que antes, mientras que sus ingresos brutos aumentaron con más velocidad que nunca. Durante estos dos años los precios de los metales alcanzaron niveles sin precedentes entonces mientras que el valor de producción de empresas canadienses incrementó rápidamente, también estaba incrementando la producción de empresas con sedes en México e 
otros países con la misma velocidad; todos se enriquecieron juntos. Durante este periodo, las empresas canadienses adquirieron minas y empezó producción en otras, pero las ganancias más grandes fueron debido a los precios de los metales y también el incremento de producción de minas existentes.

Desde 2013 la participación de las empresas canadienses se ha estancado mientras que el valor de su producción ha disminuido debido a la caída de los precios metálicos. La caída de los precios también ha afectado el entusiasmo en las inversiones y el desarrollo minero, dañando la economía de la minería metálica aún más en México.

En el futuro cercano se puede esperar ver tal participación disminuya de una manera significativa por primera vez en veinte años como resultado de la introducción de regalías en enero de 2014. La combinación de este fondo regulatorio y la caída reciente en los precios metálicos puede significar una disminución en producción para empresas canadienses operando en México en los años que vienen.

Cuadro 1: Empresas de minería metálica operando en México y valor de producción (2014)

\begin{tabular}{|c|c|c|c|c|c|}
\hline $\begin{array}{l}\text { País de } \\
\text { Orígen } \\
\end{array}$ & Empresa & Minas & Estado & Producto & $\begin{array}{l}\text { Valor de } \\
\text { Producción } \\
\end{array}$ \\
\hline \multirow{17}{*}{ Canada } & Goldcorp & $\begin{array}{l}\text { El Sauzal, Los Filos Bermejal, } \\
\text { Penasquito }\end{array}$ & $\begin{array}{l}\text { Chihuahua, } \\
\text { Guerrero, } \\
\text { Zacatecas }\end{array}$ & $\begin{array}{l}\text { Oro, Plata, } \\
\text { Plomo, Zinc }\end{array}$ & $\begin{array}{l}\$ 2.338 .807 .4 \\
87\end{array}$ \\
\hline & $\begin{array}{l}\text { Pan American } \\
\text { Silver }\end{array}$ & $\begin{array}{l}\text { Dolores, La Colorada, Alamo } \\
\text { Dorado }\end{array}$ & $\begin{array}{l}\text { Chihuahua, } \\
\text { Durango, Sonora }\end{array}$ & $\begin{array}{l}\text { Oro, Plata, } \\
\text { Cobre, Plomo, } \\
\text { Zinc }\end{array}$ & $\$ 475.931 .620$ \\
\hline & $\begin{array}{l}\text { Agnico Eagle } \\
\text { Mines }\end{array}$ & Pinos Altos, La India / Tarachi & Chihuahua, Sonora & Plata, Oro & $\$ 378.426 .522$ \\
\hline & First Majestic & $\begin{array}{l}\text { La Encantada, La Parrilla, San } \\
\text { Martin de Bolanos, La Guitarra, } \\
\text { Del Toro }\end{array}$ & $\begin{array}{l}\text { Coahuilla, } \\
\text { Durango, Jalisco, } \\
\text { Mexico, Zacatecas }\end{array}$ & $\begin{array}{l}\text { Plata, Oro, } \\
\text { Plomo, Zinc }\end{array}$ & $\$ 351.219 .597$ \\
\hline & $\begin{array}{l}\text { Primero } \\
\text { Mining }\end{array}$ & San Dimas & Durango & Oro, Plata & $\$ 321.947 .500$ \\
\hline & $\begin{array}{l}\text { Endeavour } \\
\text { Silver }\end{array}$ & Guanacevi, Bolanitos, El Cubo & $\begin{array}{l}\text { Durango, } \\
\text { Guanajuato, } \\
\text { Guanajuato }\end{array}$ & Oro, Plata & $\$ 258.834 .414$ \\
\hline & $\begin{array}{l}\text { Capstone } \\
\text { Mining }\end{array}$ & Cozamin & Zacatecas & $\begin{array}{l}\text { Plata, Plomo, } \\
\text { Cobre, Zinc }\end{array}$ & $\$ 205.950 .099$ \\
\hline & Alamos Gold & Mulatos & Sonora & Oro & $\$ 196.376 .667$ \\
\hline & Argonaut Gold & El Castillo, La Colorada & Durango, Sonora & Oro, Plata & $\$ 190.972 .692$ \\
\hline & Timmins Gold & San Francisco/La Chicharra & Sonora & Oro, Plata & $\$ 169.482 .261$ \\
\hline & Yamana Gold & Mercedes & Sonora & Oro, Plata & $\$ 156.490 .523$ \\
\hline & Fortuna Silver & San Jose & Oaxaca & Oro, Plata & $\$ 151.020 .528$ \\
\hline & New Gold Inc. & Cerro San Pedro & San Luis Potosi & Oro, Plata & $\$ 123.296 .828$ \\
\hline & AuRico Gold & El Chanate & Sonora & Oro & $\$ 94.037 .169$ \\
\hline & Sierra Minerals & Cusi, Bolivar/Val & $\begin{array}{l}\text { Chihuahua, } \\
\text { Chihuahua }\end{array}$ & $\begin{array}{l}\text { Cobre, Plata, } \\
\text { Zinc, Plomo, } \\
\text { Oro }\end{array}$ & $\$ 82.939 .810$ \\
\hline & Aurcana & La Negra & Queretaro & $\begin{array}{l}\text { Plata, Cobre, } \\
\text { Plomo, Zinc }\end{array}$ & $\$ 80.612 .209$ \\
\hline & $\begin{array}{l}\text { Great Panther } \\
\text { Silver }\end{array}$ & Topia, Valenciana & $\begin{array}{l}\text { Durango, } \\
\text { Guanajuato }\end{array}$ & $\begin{array}{l}\text { Plata, Oro, } \\
\text { Plomo, Zinc }\end{array}$ & $\$ 70.694 .457$ \\
\hline
\end{tabular}




\begin{tabular}{|l|l|l|l|l|}
$\begin{array}{l}\text { Silvercrest } \\
\text { Mines Inc. }\end{array}$ & Santa Elena & Sonora & Oro, Plata & $\mathbf{\$ 6 6 . 0 0 8 . 0 4 3}$ \\
\hline Aura Minerals & Aranzazu & Zacatecas & $\begin{array}{l}\text { Oro, Cobre, } \\
\text { Plata }\end{array}$ & $\mathbf{\$ 6 0 . 1 9 8 . 3 7 3}$ \\
\hline $\begin{array}{l}\text { Avino Silver } \\
\text { and Gold } \\
\text { Mines }\end{array}$ & Avino & Durango & Oro, Plata & $\mathbf{\$ 5 7 . 8 9 7 . 0 7 5}$ \\
\hline $\begin{array}{l}\text { McEwen } \\
\text { Mining }\end{array}$ & El Gallo & Sinaloa & Oro, Plata & $\mathbf{\$ 5 4 . 0 2 2 . 9 7 7}$ \\
\hline $\begin{array}{l}\text { Scorpio } \\
\text { Mining }\end{array}$ & Nuestra Senora & Sinaloa & $\begin{array}{l}\text { Plomo, Cobre, } \\
\text { Zinc, Plata }\end{array}$ & $\mathbf{\$ 5 2 . 3 5 8 . 7 4 8}$ \\
\hline $\begin{array}{l}\text { Excellon } \\
\text { Resources }\end{array}$ & Platosa & Durango & $\begin{array}{l}\text { Plomo, Plata, } \\
\text { Zinc }\end{array}$ & $\mathbf{\$ 4 6 . 4 3 6 . 9 7 9}$ \\
\hline $\begin{array}{l}\text { Starcore } \\
\text { International } \\
\text { Mines }\end{array}$ & San Martin & Queretaro & Oro, Plata & $\mathbf{\$ 3 3 . 7 4 7 . 4 2 1}$ \\
\hline NWM Mining & Lluivia de Oro & Sonora & Oro & $\mathbf{\$ 2 5 . 7 9 3 . 1 3 2}$ \\
\hline $\begin{array}{l}\text { ImpactSilver } \\
\text { Marlin Gold } \\
\text { Mining }\end{array}$ & Guadalupe Production Centre & Mexico & $\begin{array}{l}\text { Plomo, Cobre, } \\
\text { Zinc }\end{array}$ & $\mathbf{\$ 1 8 . 5 8 2 . 1 9 6}$ \\
\hline $\begin{array}{l}\text { Rochester } \\
\text { Resources }\end{array}$ & Mina Real & Sinaloa & Oro & $\mathbf{\$ 1 2 . 7 7 4 . 9 6 6}$ \\
\hline Goldgroup & Cerro Prieto & Nayarit & Oro, Plata & $\mathbf{\$ 8 . 6 3 1 . 5 9 8}$ \\
\hline $\begin{array}{l}\text { GoGold } \\
\text { Resources }\end{array}$ & Parral Tailings Project & Sonora & Oro, Plata & $\mathbf{\$ 6 . 8 3 4 . 7 4 7}$ \\
\hline
\end{tabular}

\begin{tabular}{|c|c|c|c|c|c|}
\hline $\begin{array}{l}\text { País de } \\
\text { Orígen }\end{array}$ & Empresa & Minas & Estado & Producto & $\begin{array}{l}\text { Valor de } \\
\text { Producción }\end{array}$ \\
\hline \multirow{5}{*}{ México } & $\begin{array}{l}\text { Industria } \\
\text { Peñoles }\end{array}$ & $\begin{array}{l}\text { Bismark, Cienega, Francisco I. } \\
\text { Madero, Fresnillo, Heradura, } \\
\text { Milpillas, Naica, Noche } \\
\text { Buena, Sabinas, Saucito, } \\
\text { Tizapa, Soledad, Velardeña }\end{array}$ & $\begin{array}{l}\text { Chihuahua, Durango, } \\
\text { Sonora, Zacatecas }\end{array}$ & $\begin{array}{l}\text { Oro, Plata, } \\
\text { Cobre, Plomo, } \\
\text { Zinc }\end{array}$ & $\$ 3.230 .908 .049$ \\
\hline & Grupo México & $\begin{array}{l}\text { Buenavista, Charcas, IMMSA, } \\
\text { La Caridad, Santa Barbara, } \\
\text { Santa Eulalia }\end{array}$ & $\begin{array}{l}\text { Sonora, San Luis } \\
\text { Potosí, Chihuahua }\end{array}$ & $\begin{array}{l}\text { Oro, Plata, } \\
\text { Cobre, Zinc, } \\
\text { Plomo, } \\
\text { Molybdenum }\end{array}$ & $\$ 3.200 .592 .903$ \\
\hline & Minera Frisco & $\begin{array}{l}\text { El Concheno, Minera Maria, } \\
\text { Ocampo, Porvenir, El Colonel, } \\
\text { Asientos, San Felipe, San } \\
\text { Francisco del Oro, Tayahua }\end{array}$ & $\begin{array}{l}\text { Aguascalientes, Baja } \\
\text { California, } \\
\text { Chihuahua, Coahuila, } \\
\text { Sonora, Zacatecas }\end{array}$ & $\begin{array}{l}\text { Oro, Plata, } \\
\text { Cobre, Zinc, } \\
\text { Plomo, } \\
\text { Molybdenum }\end{array}$ & $\$ 1,180,151,657$ \\
\hline & $\begin{array}{l}\text { Altos Hornos } \\
\text { de México }\end{array}$ & $\begin{array}{l}\text { Cerro De Mercado, Hercules, } \\
\text { Manzanillo }\end{array}$ & $\begin{array}{l}\text { Durango, Coahuila, } \\
\text { Manzanillo }\end{array}$ & Hierro & $\$ 450.864 .800$ \\
\hline & $\begin{array}{l}\text { Invecture } \\
\text { Group, } \\
\text { Frontera } \\
\text { Copper } \\
\end{array}$ & Piedras Verdes & Sonora & Cobre & $\$ 207.644 .219$ \\
\hline India & ArcelorMittal & El Volcan, Las Truchas & Michoacan, Sonora & Hierro & $\$ 512.832 .000$ \\
\hline USA & $\begin{array}{l}\text { Gold Resource, } \\
\text { Coeur Mining }\end{array}$ & El Aguila, Palmarejo & Chihuahua, Oaxaca & $\begin{array}{l}\text { Oro, Plata, } \\
\text { Cobre, Zinc, } \\
\text { Plomo }\end{array}$ & $\$ 453.693 .783$ \\
\hline
\end{tabular}




\begin{tabular}{|c|c|c|c|c|c|}
\hline $\begin{array}{l}\text { India, } \\
\text { Argenti } \\
\text { na }\end{array}$ & $\begin{array}{l}\text { Ternium, } \\
\text { ArcelorMittal }\end{array}$ & Pena Colorada & Minatitlán & Hierro & $\$ 373.940 .000$ \\
\hline $\begin{array}{l}\text { Argenti } \\
\text { na }\end{array}$ & Ternium & Alquila - Encinas & Michoacan & Hierro & $\$ 198.615 .560$ \\
\hline \multicolumn{5}{|c|}{ Valor de Producción Total: } & $\begin{array}{l}\$ 15,902,392,86 \\
1\end{array}$ \\
\hline \multicolumn{5}{|c|}{ Valor de Producción de las Empresas Canadienses: } & $\$ 6.093 .130 .293$ \\
\hline \multicolumn{5}{|c|}{ Valor de Producción de las Empresas Mexicanas: } & $\$ 8.270 .161 .629$ \\
\hline \multicolumn{5}{|c|}{ Valor de Producción de Otras Empresas Extranjeras: } & $\$ 1.539 .081 .343$ \\
\hline \multicolumn{5}{|c|}{ Participación de las Empresas Canadienses: } & $38,3 \%$ \\
\hline \multicolumn{5}{|c|}{ Participación de las Empresas Mexicanas: } & $\mathbf{5 2 , 0 \%}$ \\
\hline \multicolumn{5}{|c|}{ Participación de las Empresas de Otras Empresas Extranjeras: } & $9,7 \%$ \\
\hline
\end{tabular}

La presencia de capitales canadienses en la industria minera de México no solamente se ha caracterizado por esta reciente y rápida entrada en el mercado, sino también por la magnitud de las empresas que están basadas en Canadá. Se puede observar que las empresas que provienen de Canadá y el número de las minas que son propias de estas empresas, superan las empresas de todos los demás países combinados. Este hecho es particularmente interesante cuando se considera que los empresarios mexicanos tenían acceso a la industria minera en México por décadas antes de la afirmación de la Ley de Inversión Extranjera 1996 lo cual facilitó la entrada de empresas mineras canadienses y de otros países. Sin embargo, el cuadro 1 demuestra que solamente 5 empresas mexicanas han establecido una presencia en la industria minera, mientras que 30 empresas canadienses dominan ciertos sectores de la producción.

La razón principal por la que más empresas mexicanas no se constituyeron en el sector es que después de la crisis de deuda de los 1980s el Estado mexicano fue forzado a vender todas las minas que desarrolló durante el periodo de industrialización sustitutiva de importaciones en los 1970s. Algunos han sugerido que muchas de las minas nacionalizadas fueron vendidas a precios muy por debajo de sus valores de mercado a un pequeño grupo de empresas que hoy en día forman las tres empresas más grandes (Industria Peñoles, Grupo México y Minera Frisco) (Wise and Mendoza, 2001). El dominio de estas tres empresas en la industria y las reformas a la Ley Minera de 1991, crearon una situación casi imposible para el ingreso de empresas pequeñas o medianas en el mercado (Wise and Mendoza, 2001). E 1 cuadro 1 demuestra claramente que antes de que la industria minera mexicana fuera abierta a la inversión extranjera, existió una gran monopolio entre pocas empresas mexicanas que hoy en día está siendo desafiado por empresas canadienses junior.

Examinando la presencia de empresas canadienses, el cuadro 1 muestra que en realidad hay muy pocas empresas canadienses de grandes capitales operando en México (con ingresos brutos mayores de \$200 millones). Por lo tanto, la mayoría de empresas canadienses en producción en México son empresas pequeñas, juniors, que empezaron sus emprendimientos recientemente muchas veces exclusivamente en México. Algunos ejemplos de empresas canadienses grandes operando en México incluyen: Goldcorp, Pan American Silver, Alamos Gold, Yamana Gold and First Majestic Mining. Estas empresas se encuentran a la primera mitad de la lista como operan 
minas con mayor producción que requieren grandes montos de capital para desarrollo e inversión constante en los primeros años. La experiencia y los presupuestos de estas empresas normalmente crean una situación muy difícil para que entren empresas juniores bajo circunstancias normales, pero parece que el caso de México presenta una situación distinta.

Típicamente, las empresas junior empiezan sus operaciones con un monto pequeño de propiedades de exploración y capital suficiente para cotizar en la bolsa de valores de Toronto (TSX) lo que les permite poder juntar capital para exploración o desarrollo adicional. En la mayoría de los casos, las empresas junior venden sus propiedades con yacimientos importantes a empresas de mayor estatura y que son más capaces de desarrollar minas grandes. Sin embargo, el cuadro 1 muestra que la mayoría de las empresas canadienses en producción en México actualmente son empresas junior. Ejemplos de empresas junior en producción en México incluyen: Goldgroup, Rochester Resources, McEwan Mining, GoGold Resources and Starcore International Mines. Cuando se examina el poder económico de éstas y otras empresas junior en México se entiende que las minas que operan están en una escala más pequeña que las de sus pares mayores. La Figura 4 ayuda a explicar este fenómeno ya que se puede observar que muchas de las minas de empresas canadienses pueden ser localizadas cerca de la marca de $\$ 50$ millones.

\section{Figura 4}

\section{Ingresos Propios de Minas controladas por empresas Canadienses en México 2014 (Milliones de \$ CDN)}

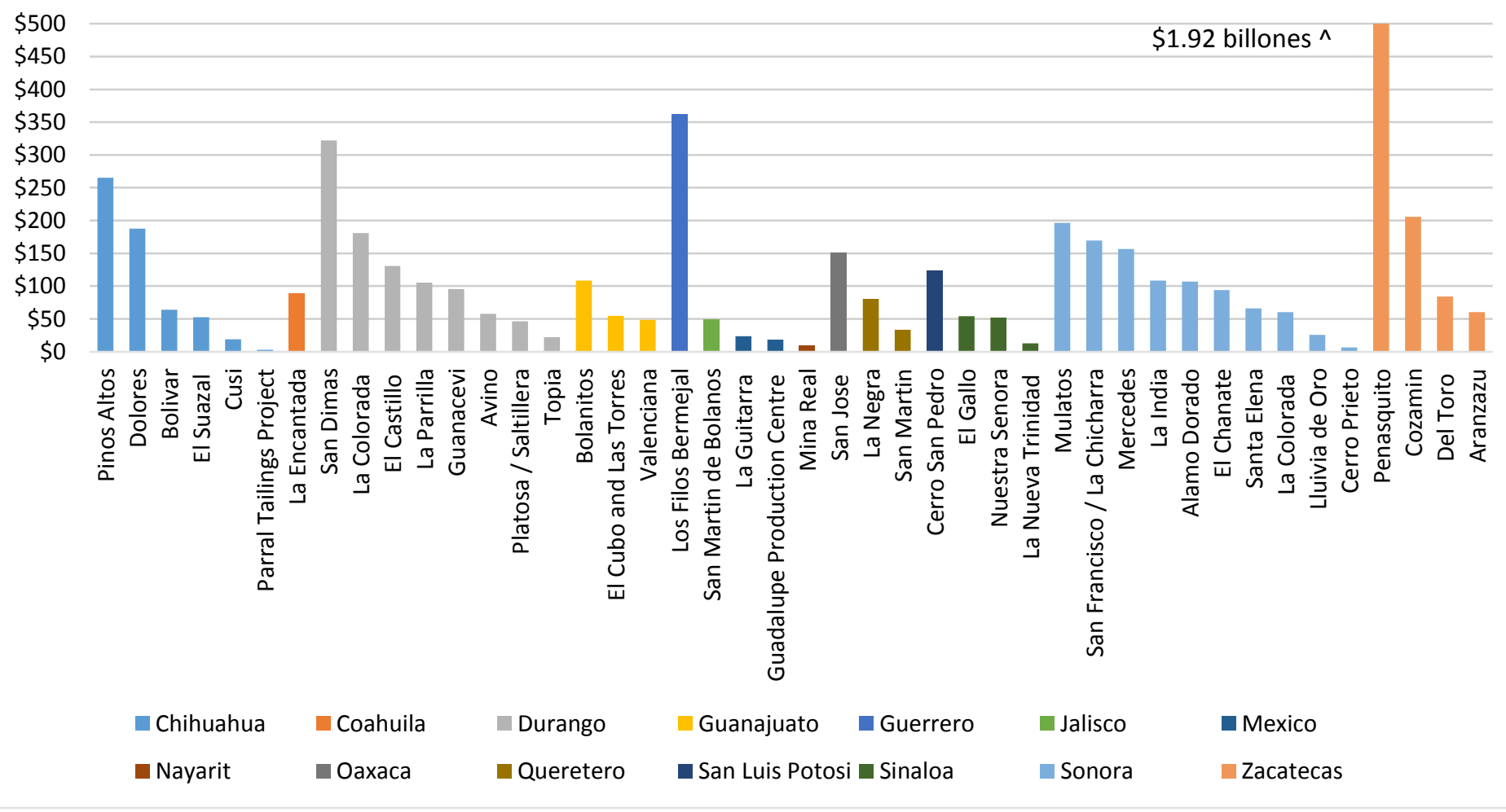


Aunque la mayoría de las empresas canadienses activas son entidades pequeñas, es necesario destacar que Goldcorp, la segunda empresa minera más grande de Canadá, es la principal empresa minera canadiense en México con un valor de producción mayor de \$2.3 billones en 2014 en solo 3 minas. La mina de oro y plata Peñasquito en Zacatecas es la mayor fuente de estos ingresos para la empresa, como se muestra en la Figura 4. Tan sólo esta mina representa casi un tercio de los ingresos brutos de todas las minas controladas por capitales canadienses en el país en 2014. Los Filos Bermejal es la segunda mina canadiense más grande, también controlada por Goldcorp, y trae casi todo lo restante de la producción de la empresa. La tercera mina de esta empresa, El Sauzal, marcó la entrada de Goldcorp en el sector minero metálico y dominó la participación canadiense entre 2005 a 2009 al tiempo de hacer de Goldcorp la empresa minera extranjera más importante en este nuevo periodo.

Es interesante notar que cada una de las empresas mexicanas en el Cuadro 1 tiene valores de producción muy por arriba de casi todas las empresas canadienses que tienen presencia en la industria. Los ingresos brutos combinados de Industria Peñoles y Grupo México sobrepasan la participación de todas las empresas canadienses combinadas. De la misma forma, todas las empresas activas constituidas en otros países (India, Argentina, EEUU, UK) también muestran mayores niveles de producción que la mayoría de las empresas canadienses. Sin embargo, es importante notar que es la presencia colectiva y cada vez más poderosa de todas las empresas canadienses combinadas que ha dejado una marca en el debate contemporáneo acerca de la extracción minera en México.

\section{$\underline{\text { Fuentes }}$}

Larkin, Nicholas "The Rise and Fall of Gold" June 23, 2015 Bloomberg QuickTake, http://www.bloombergview.com/quicktake/the-fall-of-gold, accessed July 24, 2015.

“Market Commentary Third Quarter 2015” World Gold Council, July 23, 2015.

Roy, Deberarti "Gold rout will deepen, prices will drop below US\$1,000: Goldman Sachs" Financial Post, July 22, 2015.

Wise and Mendoza, "Minería, Estado y Gran Capital en México" Economía y Sociedad: 105-127 (2001). 
Appendix 3: Most Common Questions that were used in Interviews for the Thesis project:

\section{Canadian Metal Mining in Mexico}

1. What are the main obstacles in increasing and improving trade relations in mining between Canada and Mexico?

2. Which services provided by the Trade Commission are most important for a Canadian mining company seeking to invest in Mexico for the first time?

3. How would you describe the relationship between the Trade Commission and the Canadian Mining Task Force?

4. How has the Trade Commission helped Canadian mining companies adjust to the new mining laws?

5. ¿Cuál cree usted es la contribución más importante de (name of Company here) al desarrollo económico de México?

6. ¿Cuál sería, según su percepción la diferencia fundamental entre una empresa minera extranjera canadiense e una empresa nacional mexicana?

7. ¿Cuáles son, en su opinión, las razones por las cuales la participación canadiense en el sector minero mexicano llegó a crecer tan rápidamente durante los últimos 5 años?

8. ¿Cuál fue la posición de (name of Company here) durante las discusiones acerca de la implementación de las reformas sobre los derechos mineros en enero de 2014?

9. Qué tipo de dialogo tiene (name of Company here) con el gobierno nacional acerca del asunto? ¿CAMIMEX?

10. ¿En qué forma la introducción de las nuevas regalías ha afectado a las acciones financieras de (name of Company here)?

11. Qué ha afectado más a los asuntos financieros de (name of Company here) en México, la bajada de los precios metales, o las regalías?

12. ¿Cómo ve usted la inversión extranjera en el sector minero en los próximos 3-5?

13. Entiendo que (name of Company here) es un miembro activo en la cámara minera mexicana. ¿Desde la punta de vista de usted como contador, que función se cree usted es la más importante de CAMIMEX para (name of Company here)? 


\section{References}

Acemoglu, Daron, Johnson, Simon and Robinson, James, "The Colonial Origins of Development: An Empirical Investigation", The American Economic Review 91.5 (2001): 13691401.

Appendix 1: Mining Production in Mexico, 1996-2014.

This refers to a complex dataset I created for my thesis project which production data, geographical information, employment and other figures for each mine in production in Mexico from 1996-2014. The data was used to make conclusions in the preceding Empirical Findings chapter regarding Canadian participation in Mexico's metal mining industry.

Auditorio General, Análisis de Avance de Informe de Avance de Gestión Financiera, 2014: 1199.

Auditoría Financiera y de Cumplimiento, "Derechos sobre Minería”, Informe del Resultado de la Fiscalización Superior de la Cuenta Pública 2010.

Auditoría Financiera y de Cumplimiento, "Otorgamiento de Concesiones e Ingresos por Derechos en Materia Minera", Informe del Resultado de la Fiscalización Superior de la Cuenta Pública 2012.

Azamar, Aleida and Ponce, Jose Ignacio, "Extactivismo y Desarrollo: Los Recursos Minerales en México", Revista Problemas del Desarrollo 179.45 (2014): 137-158.

Baer, Werner, "Import Substitution and Industrialization in Latin America: Experiences and Interpretations", Latin American Research Review 7.1 (1972): 95-122.

Bebbington, Anthony, "The New Extraction: Rewriting the Political Ecology of the Andes?", NACLA Report on the Americas (2009): 12-40.

Bernstein, Marvin, The Mexican Mining Industry 1890-1950 (State University of New York, New York: 1965).

Boas, Taylor and Gans-morse, Jordan, "Neoliberalism: From New Liberal Philosophy to AntiLiberal Slogan”, Studies in Comparative International Development 44.2 (2009): 137-161.

Bocking, Paul, "Canadian Mining and Labour Struggles in Mexico", Journal of Labour and Society 2013: 331-350.

Burchardt, Hans-Jurgen and Dietz, Kristina, "Neo-Extractivism - A New Challenge for Development Theory from Latin America", Third World Quarterly 35.3 (2014): 468-486.

CAMIMEX, Informe Anual 2015, "Situación de la Minería en México en 2014", LXXVIII Asamblea General Ordinaria.

CBC News online, "McEwen Mining says armed robbers stole 7,000 ounces of gold from their Mexican mine", by Pete Evans, April 8, 2015, http://www.cbc.ca/news/business/mcewen- 
mining-says-armed-robbers-stole-7-000-ounces-of-gold-from-their-mexican-mine-1.3024579, accessed February 15, 2016.

Coase, Ronald, “The New Institutional Economics”, American Economic Review 88.2 (1998): 72-74.

Coase, Ronald, “The Problem of Social Cost", The Journal of Land and Economics 3 (1960): 144.

Comisión Económica para América Latina y el Caribe de la Naciones Unidas (UNCEPAL), "La inversión extranjera directa de Canadá en América Latina y el Caribe”, chapter in La Inversión Extranjera en América Latina y el Caribe: 155-208.

CONEVAL, "Medición de Pobreza: Resultados de Pobreza por Municipio", http:/www.coneval.gob.mx/Medicion/MP/Paginas/Anexo-estad\%C3\%ADstico-municipal2010.aspx, accessed February 4, 2016.

Costero, Cecilia, "La regionalización de las relaciones inter-nacionales, la inversión canadiense en San Luis Potosí, vista a través de Minera San Xavier", Revista Mexicana de Estudios Canadienses, 3.4 (2000): 105-117.

Deloitte, Mining Industry in Mexico, May 2012.

Deloitte Touche Tohmatsu Limited website, “Taxation and Investment in Mexico 2014", http://www2.deloitte.com/content/dam/Deloitte/global/Documents/Tax/dttl-tax-mexicoguide2014.pdf, accessed January 122016.

Deneault, Alain and Sacher, William, Imperial Canada Inc.: Legal Haven of Choice for the World's Mining Industries (Vancouver, Talonbooks: 2012).

Enciso, Angélica, La Jornada, "Deja Minera San Xavier un daño irreversible en San Luis Potosí”, April 142014.

Forbes Magazine online, "Mexico Among The World's Most Corrupt Nations In 2014", December 11, 2014, http://www.forbes.com/sites/doliaestevez/2014/12/11/mexico-among-theworlds-most-corrupt-nations-in-2014-new-report-says/\#6378e4c73258, accessed February 4, 2016.

Forbes website, "The World's Billionaires”, http://www.forbes.com/billionaires/list/\#country:Mexico, accessed on January 19, 2016.

Garibay, Claudio and Camacho, Alejandra, "Goldcorp y la Reprocidad Negativa en el Paisaje Minero de Mezcala, Guerrero”, UNAM Desacates (2009): 91-110.

Garibay, Claudio et. al, "Unequal Partners, Unequal Exchange: Goldcorp, the Mexican State, and Campesino Dispossession at the Peñasquito Goldmine", Journal of Latin American Geography 10 (2011): 153-176. 
Garrod, J.Z. and Macdonald, Laura, 'Rethinking 'Canadian Mining Imperialism' in Latin America", chapter in Mining in Latin America: Critical Approaches to the New Extraction Ed. Deonandan, Kalowatie and Dougherty, Michael L. (London: Routledge, 2016).

Global Affairs Canada, Mexico Country Profile, Canada's Global Market Action Plan, http://international.gc.ca/global-markets-marches-mondiaux/sectorssecteurs/mines.aspx?lang=eng, accessed on September 25, 2015.

Global Affairs Canada website, Fact Sheet: Mexico - Canada's Priority Market, http://international.gc.ca/global-markets-marches-mondiaux/markets-marches/mexicomexique.aspx?lang=eng, accessed on January 13, 2016.

Global Affairs Canada website, http://international.gc.ca/global-markets-marchesmondiaux/markets-marches/mexico-mexique.aspx?lang=eng, accessed on January 13, 2016.

Gordon, Todd and Webber, Jeffrey, "Imperialism and Resistance: Canadian Mining Companies in Latin America", Third World Quarterly 29.1 (2008): 63-87.

Government of Canada document, The Americas: Canada's Strategy for Engagement in the Americas, www.americas.gc.ca, accessed on September 25, 2015.

Gudynas, Eduardo, "Nationalisms of Natural Resources and the Compensatory State of Progressive South America", chapter in forthcoming book.

Gutiérrez Haces, María Teresa, "The Dominance of Mexican Business Groups in the Mining Sector in the Context of the Growing Presence of Canadian Mining Companies”, 2016 forthcoming: 1-22.

Harvey, David, “The 'new' Imperialism: Accumulation by Dispossession”, Socialist Register 40 (2004): 63-87.

Instituto Nacional de Estadística y Geografía (INEGI) website, “Censo de Población y Vivienda", http://www.inegi.org.mx/sistemas/consulta_resultados/iter2010.aspx?c=27329\&s=est, accessed February 4, 2016.

Instituto Nacional de Estadísticas y Geografía, Estadísticas de Exportaciones Mineras, Cuadro 77, 3.2.1, (INEGI), 2014.

Instituto Nacional de Estadística y Geografía (INEGI) website, “Ocupación y Empleo: Remuneraciones", http://www3.inegi.org.mx/sistemas/sisept/default.aspx?t=eemp20\&s=est\&c=25700, accessed January 19, 2016.

Kessler, Timothy, "Political Capital: Mexican Financial Policy under Salinas", World Politics 51.1 (1998): n/a. 
Klein, Peter, "New Institutional Economics” University of Georgia, (1999): 456-489.

Macdonald, Laura and Mahone, Rianne "Poverty Policy and Politics in Canada and Mexico: 'Inclusive' Liberalism?”, chapter in Post-Neoliberism in the Americas, eds. Laura Macdonald and Anne Ruckert, (Hampshire: Palgrace Macmillan: 2009): 184-198.

Maier et al. "Socially Responsible Mining: the Relationship Between Mining and Poverty, Human Health and the Environment", Revision Environ Health 29.2 (2014): 83-89.

"Mining Taxes for Argentina", Price Waterhouse Coopers website, http:/www.pwc.com/gx/en/industries/energy-utilitiesmining/mining/territories/argentina.html\#footnote-14, accessed March 28, 2016.

Moore, Jennifer and Colgrove, Gillian, "Corruption, Murder and Canadian Mining in Mexico: The Case of Blackfire Exploration and the Canadian Embassy", report prepared by Mining Watch Canada (May 2013).

Noreste News online, “Asesinan a familia minera en Pánuco”, June 26, 2015, http://www.noroeste.com.mx/publicaciones.php?id=1038693, accessed February 15, 2015.

North, Douglass, “Institutions, Institutional Change and Economic Performance” (Cambridge: Cambridge University Press: 1990).

North, Douglass, "New Institutional Economics and Third World Development", chapter in The New Institutional Economics and Third World Development (London: Routledge, 1995): 17-27.

North, Douglass, "Structure and Performance: The Task of Economic History", Journal of Economic Literature 16.3 (1978): 963-978.

North, Douglass, “The Adam Smith Address: Economic Theory in a Dynamic Economic World”, Business Economics 30.1 (1995): 7-12.

O’Faircheallaigh, Ciaran, Mining and Development (New York, St. Martin's Press: 1984).

Otto, James et. al., Mining Royalties: A Global Study of Their Impact on Investors, Government and Civil Society (Washington DC, The World Bank: 2006).

Petras, James \& Veltmeyer, Henry, Beyond Neoliberalism (Globalization, Crisis, and Change), (England, Ashgate: 2011).

Puyana Mutis, Alicia, "La Economía Petrolera en un Mercado Politizado y Global - Mexico y Colombia” (México: FLACSO México, 2015).

Puyana, Alicia and Moreno-Brid, Juan Carlos, "Mexico's New Wave of Market Reforms and its Extractive Industries", chapter in forthcoming book (2016). 
Puyana, Alicia and Romero, José, "La Economia Mexicana después de Dos Decenias de Reformas", Comercio Exterior 57.16 (2007): 780-799.

Reygadas, Pedro and Reyna Jimenez, Oscar Felipe, "La batalla por San Luis: ¿el agua o el oro? La disputa argumentativa contra la Minera San Xavier”, Estudios Demográficos y Urbanos 2.68 (2008): 299-331.

Richter, Rudolf, "The New Institutional Economics: Its Start, its Meaning and its Prospects", European Business Organization Law Review 6 (2005): 161-200.

Secretary of the Economy, Coordinación General de Minería, "Principales Minas y Proyectos Avanzados" demonstration in information folder, "La Minería es una Industria Comprometida con las Comunidades y el Medio Ambiente" distributed October 2015.

Secretary of the Economy: document provided October 2015, "Exportaciones Minero Metalúrgicas por País 2010-2015”, by the General Mining Coordination Office, PRONTUARIO: Industria Minero Metalúrgica, Septiembre 2015: 1-54.

Servicio Geologico Mexico, "Statistical Yearbook of the Mexican Mining 2014", http://www.sgm.gob.mx, accessed April 8, 2015.

SNL Metals and Mining, "World Exploration Trends 2015", prepared for PDAC International Mining Convention, 2015.

Statistics Canada, "Employment by Industry”, http:/www.statcan.gc.ca/tables-tableaux/sumsom/101/cst01/econ40-eng.htm, accessed January 23, 2016.

Tamos Bos et. al, "Innovation, Entrepreneurship and Clusters in Latin America: Natural Resources - Implications and Future Challenges”, Journal of Technology Management and Innovation 3.4 (2008): 52-63.

Teichman, Judith, "Economic Restructuring, State-Labor Relations, and the Transformation of Mexican Corporatism" chapter in Neoliberalism Revisited: Economic Restructuring and Mexico's Political Failure edited by Gerardo Otero, (Westview Press, 1996: Colorado): 149-167.

Tetreault, Darcy, "Free Market Mining in Mexico", Critical Sociology (2014): 1-14.

Tetreault, Darcy, "Megaminería en México: ¿Un Camino hacía el Desarrollo Local and Nacional?”, Estudios Críticos del Desarrollo 4.7 (2014): 101-130.

Tetreault, Darcy “Resistance and Reform in Mexico's Mining Sector" chapter in Extractive Imperialism in the Americas: Capitalism's New Frontier (Boston: Brill, 2014): 194-233.

Thacker, Strom "Big Business, the State and Free Trade: Constructing Coalitions in Mexico" (Cambridge University Press, New York: 2000).

Toye, John, "The New Institutional Economics and its Implications for Development Theory" chapter in The New Institutional Economics and Third World Development edited by John Harris, Janet Hunter and Colin Lewis (London: Routledge, 1995): 49-71. 
United Nations Conference on Trade and Development (UNCTAD), "World Investment Report 2007 - Transnational Corporations, Extractive Industries and Development”: 1-323.

Veltmeyer, Henry, “The Natural Resource Dynamics of Post-Neoliberalism in Latin America: New Developmentalism or Canadian Extractivist Imperialism?” Draft prepared for presentation and discussion at Global Capital and Global Rights workshop SFU-UBC (2012): 1-63.

Wise, Raúl and Mendoza, Rubén "Minería, Estado y gran Capital en México", Economía e Sociedad 16 (2001): 105-127.

Wong Dan, Ángel Tomás “Análsis de Crecimiento y Desarrollo de Grupo México en la Industría Minera", Facultad de Ciencias Económicas y Empresariales. 15.1 (2015): 104- 113.

World Bank and Norad Conference: "From Curse to Development: Natural Resources, Institutions and Public Revenues" Oslo, Norway (2011): 1-30.

World Bank website, "Data: Labour Force by Country", http://data.worldbank.org/indicator/SL.TLF.TOTL.IN, accessed on January 13, 2016.

World Bank, “Implementation Completion Report”, Report Number: 18856, December 1996: 6. http://www-

wds.worldbank.org/external/default/WDSContentServer/WDSP/IB/1999/08/15/000094946_9903 2505561818/Rendered/PDF/multi_page.pdf

World Bank "Memorandum and Recommendation for a proposed \$200 million loan to the United Mexican States for Mining Sector Reconstruction", Report Number: P-5512-ME, May 1991: 2. http://wwwwds.worldbank.org/external/default/WDSContentServer/WDSP/IB/1991/05/30/000009265_3961 001074548/Rendered/PDF/multi_page.pdf

Yates, Julian and Bakker, Karen, "Debating the 'post-neoliberal turn' in Latin America", Progress in Human Geography 38.1 (2014):62-90.

Zacatecas en Imagen, "Aviadores y proveedor de Mazapil tienen tomada la presidencia”, February 25, 2014, http:/www.imagenzac.com.mx/nota/aviadores-y-proveedor-de-mazapiltienen-23-20-06-2k, accessed February 4, 2016. 